\title{
Technetium Sorption Media Review
}

Author Name:

J.B. Duncan, S.E. Kelly, R.A. Robbins, R.D. Adams, M.A. Thorson / C.C. Haass

Washington River Protection Solutions, LLC / AEM Consulting, LLC

Richland, WA 99352

U.S. Department of Energy Contract DE-AC27-08RV14800

\begin{tabular}{|c|c|c|c|}
\hline EDT/ECN: & & UC: & \\
\hline Cost Center: & $2 \mathrm{GH} 00$ & Charge Code: & 200993 \\
\hline B\&R Code: & & Total Pages: & 92 \\
\hline
\end{tabular}

Key Words: ABEC, ABEC 2000, Dowex, Dowex 1X8, Immobilization, Ion Exchange, Kurion, LAW, Low Activity Waste, Purolite, Purolite A520E, Purolite A530E, Reillex, Reillex HPQ, Sn(II) Apatite, SuperLig, SuperLig 639, Supplemental Immobilization, Ion Exchange, TAM, Tc, Tc-99, Tc(VII), Technetium, Tin Apatite, Pertechnetate

Abstract: This report presents information and references to aid in the selection of $99 \mathrm{Tc}$ sorption media for feasibility studies regarding the removal of $99 \mathrm{Tc}$ from Hanford's low activity waste. The report contains literature search material for sorption media (including ion exchange media) for the most tested media to date, including SuperLig 639, Reillex HPQ, TAM (Kruion), Purolite A520E and A530E, and Dowex $1 \times 8$.

TRADEMARK DISCLAIMER. Reference herein to any specific commercial product, process, or service by trade name, trademark, manufacturer, or otherwise, does not necessarily constitute or imply its endorsement, recommendation, or favoring by the United States Government or any agency thereof or its contractors or subcontractors.
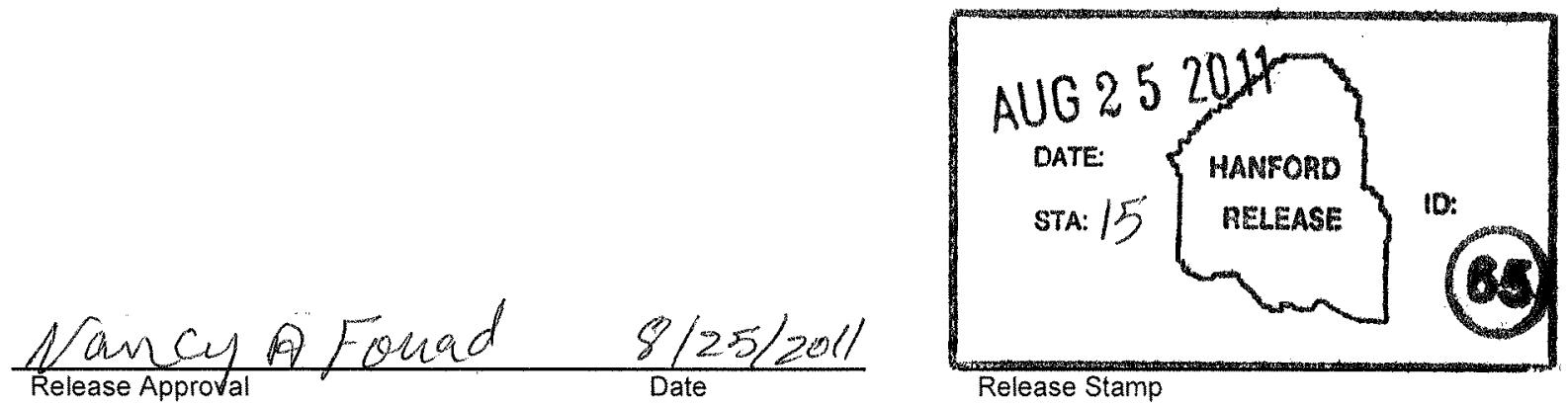

Approved For Public Release 
RPP-RPT-50122

Revision 0

\section{Technetium Sorption Media Review}

Prepared for the U.S. Department of Energy

Assistant Secretary for Environmental Management

Contractor for the U.S. Department of Energy

Office of River Protection under Contract DE-AC27-08RV14800

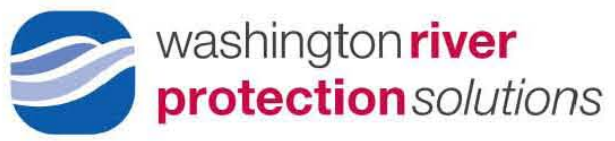

P.O. Box 850

Richland, Washington 99352 
RPP-RPT-50122

\section{TABLE OF CONTENTS}

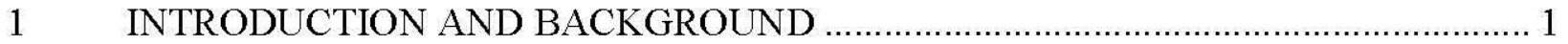

2 BASICS OF SORPTION MEDIA, TECHNETIUM, LOW-ACTIVITY WASTE, AND COLUMNS

2.1 ION EXCHANGE / RESIN / SORBENT MEDIA / SORPTION MEDIA .................... 4

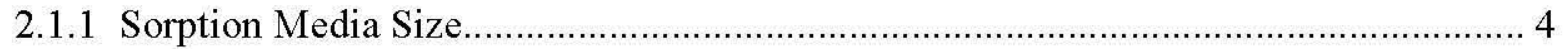

2.2 ELUTABLE AND NON-ELUTABLE SORPTION MEDIA …….................................. 4

2.3 BATCH DISTRIBUTION COEFFICIENT AND COLUMN DISTRIBUTION RATIO. 5

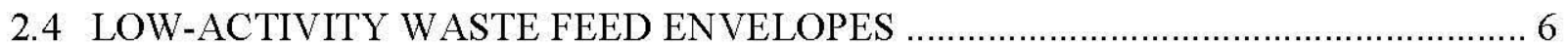

2.5 POTENTIAL AND PH EFFECT ON TECHNETIUM SPECIES .................................. 6

3 IMMOBILIZATION SORPTION MEDIA EVALUATION CRITERA......................... 8

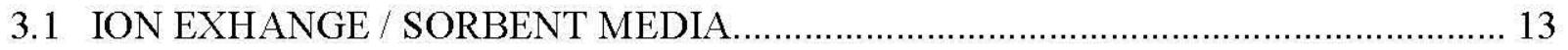

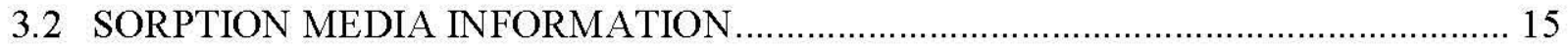

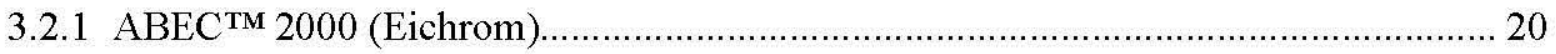

3.2.1.1 Overview of Literature Reports for ABEC 2000 .....................................20

3.2.2 Dowex ${ }^{\mathrm{TM}}$ 1-X8 (Dow Chemical) ........................................................................ 21

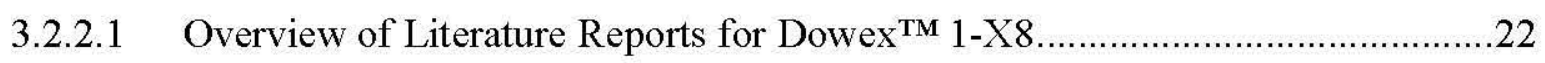

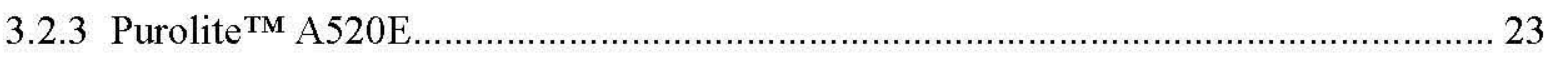

3.2.3.1 Overview of Literature Reports for Purolite ${ }^{\mathrm{TM}}$ A520E ...................................24

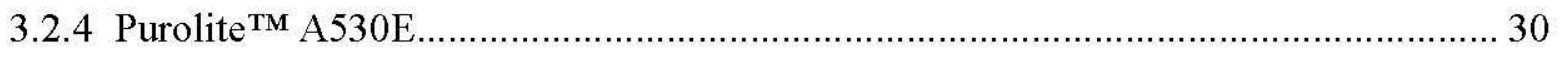

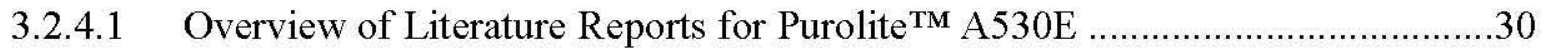

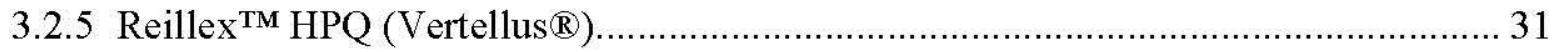

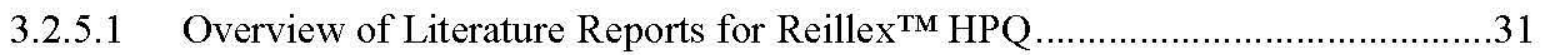

3.2.6 $\mathrm{TAM}^{\mathrm{TM}}$ or Sn(II) Apatite Microspheres (Kurion, Inc ) ….................................... 37

3.2.6.1 Overview of Literature Reports for TAM …............................................37

3.2.7 SuperLig® 639 (IBC Advanced Technologies, Inc.) ........................................... 38

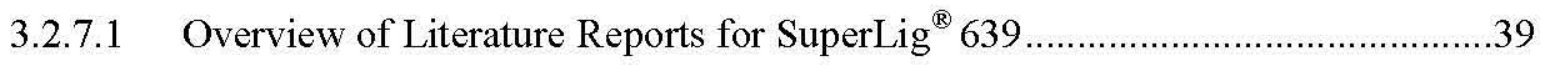

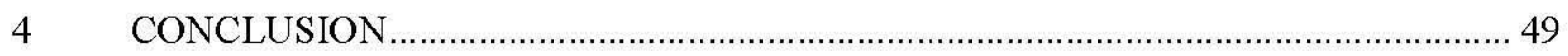

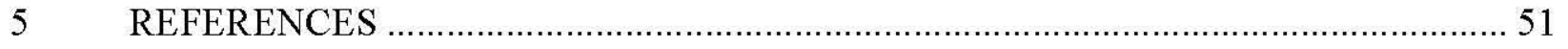

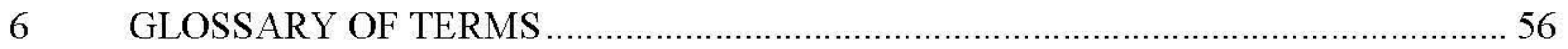


RPP-RPT-50122

\section{APPENDICES}

APPENDIX A SORPTION MEDIA REFERENCE MATRIX …………............................. A-1

APPENDIX B VENDOR INFORMATION ..................................................................... B-1

\section{LIST OF FIGURES}

Figure 1-1. Simplified Supplemental Treatment Flow Diagram ............................................ 2

Figure 2-1. Technetium Species (Guillaumont, et al., 2003)…….......................................... 7

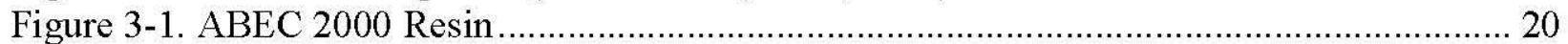

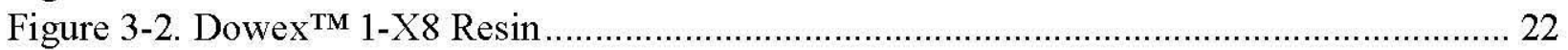

Figure 3-3. Newly-Generated Liquid Low-Level Waste Simulate Composition (K/TCD-1141) 23

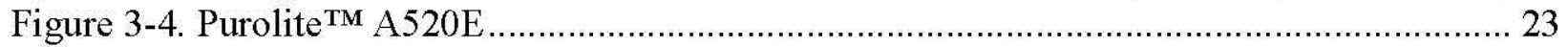

Figure 3-5. Tank SY-102 Alkaline Supernate Simulant (Table 2, LA-12654, Rev.)................... 25

Figure 3-6. Results by Adsorber for Technetium (LA-12654 Rev.)........................................ 26

Figure 3-7. Purolite ${ }^{\mathrm{TM}}$ A520E Distribution Coefficients by Analyte (LA-12654 Rev.)............... 26

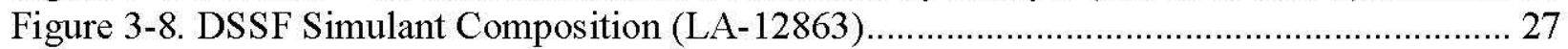

Figure 3-9. Results by Adsorber for Technetium (LA-12863) ............................................... 28

Figure 3-10. Purolite TM A520E Distribution coefficients by Analyte (LA-12863) ...................... 28

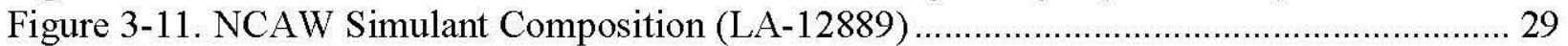

Figure 3-12. Results by Adsorber for Technetium (LA-12889) ………………....................... 29

Figure 3-13. Purolite ${ }^{\mathrm{TM}}$ A520E Distribution coefficients by Analyte (LA-12889) ………............ 29

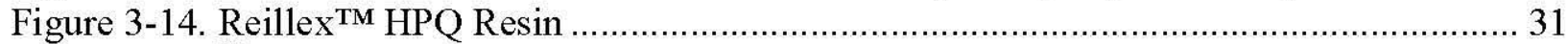

Figure 3-15. ${ }^{99} \mathrm{Tc}$ Batch Adsorption Data for MVST W-29 Supernate (CONF-9505101-1) .... 32

Figure 3-16. Reillex ${ }^{\mathrm{TM}}$ HPQ Distribution Coefficients by Analyte (LA-12654 Rev.).................. 34

Figure 3-17. Reillex ${ }^{\mathrm{TM}}$ HPQ Distribution Coefficients by Analyte (LA-12863) ……………....... 35

Figure 3-18. Reillex ${ }^{\mathrm{TM}}$ HPQ Distribution Coefficients by Analyte (LA-12889) ……………...... 36

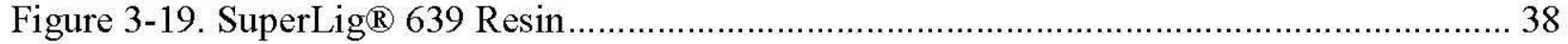

Figure 3-20. Batch Contact Data (BNF-003-98-230) ………............................................ 40

Figure 3-21. ${ }^{99} \mathrm{Tc} \mathrm{K}_{d} \mathrm{~s}$ for SuperLig ${ }^{\circledR} 639$ for Tank AW-101 Waste (BNFL-RPT-009) ............... 41

Figure 3-22. Equilibrium Distribution Coefficient Table for Te Removal (WSRC-TR-2003-

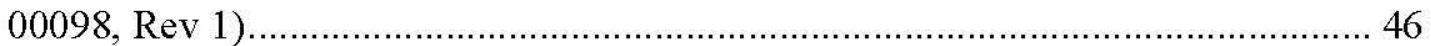

Figure 3-23. Breakthrough Curves for SuperLig 639 on AW-101 Waste (WSRC-TR-2003-

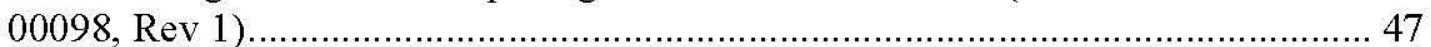

Figure B-1. ABEC TM 2000 Page 1............................................................................. B-1

Figure B-2. ABECTM 2000 Page 2 …………………………………………... B-2

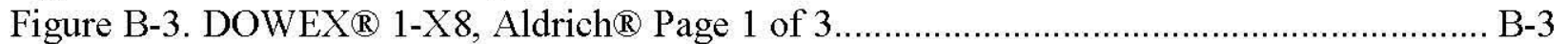

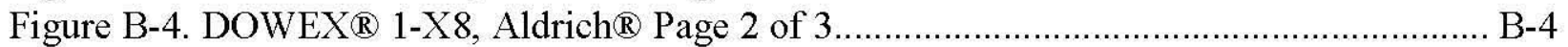

Figure B-5. DOWEX ${ }^{\circledR} 1-X 8$, Aldrich ${ }^{\circledR}$ Page 3 of 3 ……........................................... B-5

Figure B-6. DOWEX ${ }^{\mathrm{TM}}$ 1-X8 Cost from GFS Chemicals (supplier/non-bulk) ………............. B-6

Figure B-7. DOWEX ${ }^{\mathrm{TM}}$ 1-X8 Supplier Information ……………………………............ B-7

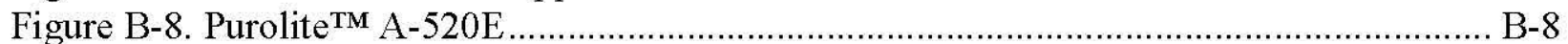

Figure B-9. Purolite ${ }^{\mathrm{TM}}$ A-530E …………………….............................................. B-9

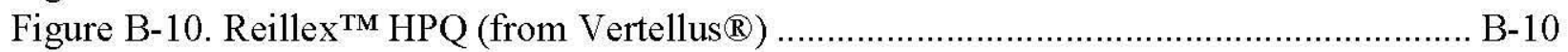

Figure B-11. SuperLig® Vendor Information (page 1 of 3) ............................................... B-11

Figure B-12. SuperLig® Vendor Information (page 2 of 3)............................................. B-12 
RPP-RPT-50122

Figure B-13. SuperLig® Vendor Information (page 3 of 3) B-13

Figure B-14. TAM (Kurion, Inc )

\section{LIST OF TABLES}

Table 2-1. Reference Table for Conversion of Mesh Size to Inches or Micrometers ................... 4

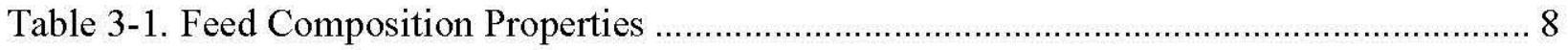

Table 3-2. Criteria for Evaluation of Sorbent Media ......................................................... 9

Table 3-3. Ion Exchange Feed Solution Applicability Criteria ${ }^{a}$.......................................... 11

Table 3-4. Sorption Media Characteristics Required for a more In-Depth Evaluation ............... 12

Table 3-5. Ion Exchange / Sorbent Media Initial Screening Results ..................................... 13

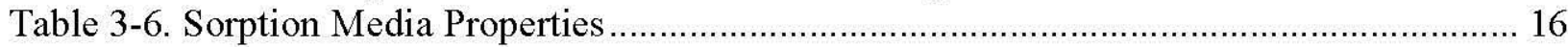

Table 3-7. Solution Properties (CONF-9505101-1) …..................................................... 32

Table 3-8. Concentrations of Selected Analytes in the Hanford Tank Waste Supernates (WSRC-

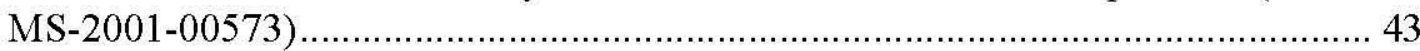

Table 3-9. Hanford AN-103 vs. Savannah River 44F (extracted from WSRC-MS-2001-00760) 44

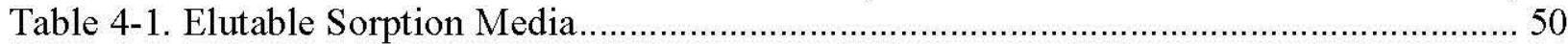

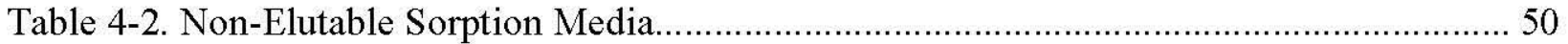

Table A-6-1. Sorption Media References by Feed Solution................................................. A-1 
RPP-RPT-50122

\section{LIST OF TERMS}

\begin{tabular}{|c|c|}
\hline${ }^{99} \mathrm{Tc}$ & Technetium-99 (99-Tc, Tc-99) \\
\hline $\mathrm{Al}^{+3}$ & Aluminum \\
\hline BNFL & British Nuclear Fuels, Ltd \\
\hline BNI & Bechtel National, Inc. \\
\hline BV & Bed volume \\
\hline $\mathrm{CC}$ & Complex Concentrate \\
\hline $\mathrm{Ci}$ & Curie \\
\hline $\mathrm{Cl}$ & Chlorine \\
\hline $\mathrm{cP}$ & Centipoise \\
\hline $\mathrm{Cr}$ & Chromium \\
\hline $\mathrm{CV}$ & Column volume \\
\hline DF & Decontamination factor \\
\hline DNFSB & Defense Nuclear Facilities Safety Board \\
\hline $\mathrm{DOE}$ & U.S. Department of Energy \\
\hline DSSF & Double-shell Slurry Feed \\
\hline DST & Double-shell tank \\
\hline Ecology & Washington State Department of Ecology \\
\hline EMS & Environmental Management System \\
\hline EPA & U.S. Environmental Protection Agency \\
\hline $\mathrm{Eq}$ & Equivalents \\
\hline $\mathrm{ES}$ & EnergySolutions \\
\hline ETF & Effluent Treatment Facility \\
\hline $\mathrm{F}$ & Fluorine \\
\hline FY & Fiscal year \\
\hline $\mathrm{g}$ & Gram \\
\hline gmol & Gram-mole \\
\hline HFFACO & Hanford Federal Facility Agreement and Consent Order \\
\hline HLW & High-level waste \\
\hline hr & Hour \\
\hline IDF & Integrated Disposal Facility \\
\hline ILAW & Immobilized low-activity waste \\
\hline IX & Ion exchange \\
\hline $\mathrm{K}^{+}$ & Potassium \\
\hline $\mathrm{K}_{\mathrm{d}}$ & Distribution coefficient \\
\hline$\lambda$ & Column distribution ratio \\
\hline LAW & Low-activity waste \\
\hline LLW & Low level waste \\
\hline M & Molar (gram-moles/liter) \\
\hline $\mathrm{ml}$ & Milliliter \\
\hline MT & Metric-tons \\
\hline MVST & Melton Valley Storage Tanks \\
\hline $\mathrm{Na}^{+}$ & Sodium \\
\hline NEPA & National Environmental Protection Act \\
\hline $\mathrm{NO}_{2}^{-}$ & Nitrite \\
\hline $\mathrm{NO}_{3}^{-}$ & Nitrate \\
\hline
\end{tabular}




\begin{tabular}{|c|c|}
\hline NPH & Normal paraffin hydrocarbon \\
\hline $\mathrm{OH}^{-}$ & Hydroxide \\
\hline ORNL & Oak Ridge National Laboratory \\
\hline ORP & U.S. Department of Energy, Office of River Protection \\
\hline PFD & Process Flow Diagram \\
\hline PNNL & Pacific Northwest National Laboratory \\
\hline $\mathrm{PO}_{4}^{-3}$ & Phosphate \\
\hline PEG & Polyethylene glycol \\
\hline PT & Pretreatment \\
\hline$\rho_{b}$ & Bulk density \\
\hline $\mathrm{R}$ & Radiation absorbed dose (Rad) \\
\hline $\operatorname{Re}$ & Rhenium \\
\hline RPP & River Protection Project \\
\hline SME & Subject Matter Expert \\
\hline $\mathrm{SO}_{4}^{-2}$ & Sulfate \\
\hline SRNL & Savannah River National Laboratory \\
\hline SRS & Savannah River Site \\
\hline SST & Single-shell tank \\
\hline TBP & Tri-butyl phosphate \\
\hline $\mathrm{TcO}_{4}^{-}$ & Pertechnetate \\
\hline TPA & Tri-Party Agreement \\
\hline TRL & Technology Readiness Level \\
\hline TWRS & Tank Waste Remediation System \\
\hline WRPS & Washington River Protection Solutions, LLC \\
\hline WTP & Waste Treatment and Immobilization Plant \\
\hline
\end{tabular}


RPP-RPT-50122

\section{INTRODUCTION AND BACKGROUND}

The U.S. Department of Energy (DOE), Office of River Protection (ORP) is responsible for management and completion of the River Protection Project (RPP) mission, which comprises both the Hanford Site tank farms and the Waste Treatment and Immobilization Plant (WTP). The RPP mission is to store, retrieve and treat Hanford's tank waste; store and dispose of treated wastes; and close the tank farm waste management areas and treatment facilities in a safe, environmentally compliant, cost-effective and energy-effective manner.

The Hanford Federal Facility Agreement and Consent Order (HFFACO or Tri-Party Agreement [TPA]) requires DOE to complete the RPP tank waste treatment mission by September 30, 2047. A key aspect of implementing that mission is to construct and operate the WTP (ORP-11242, Rev. 5, River Protection Project System Plan). The WTP is a multi-facility plant that will separate and immobilize the tank waste for final disposition. The WTP Low-Activity Waste (LAW) Vitrification Facility is sized to treat about 40 to $50 \%$ of the approximately 60,000 to 80,000 metric tons (MT) of tank farm sodium waste requiring treatment by 2047.

The RPP work scope is currently performed by two primary contractors: Washington River Protection Solutions (WRPS), the Tank Operations Contractor (TOC); and Bechtel National, Inc. (BNI), the WTP Construction and Commissioning Contractor. Washington River Protection Solutions is responsible for the construction, operation and maintenance activities necessary to store, retrieve and transfer tank wastes; provide supplemental pretreatment for tank waste; and provide second LAW treatment, storage and/or disposal of immobilized product and secondary waste streams. Bechtel National, Inc. is responsible for the design, construction, and commissioning of a WTP Pretreatment Facility, two vitrification facilities (one for high-level waste $[\mathrm{HLW}]$ and one for LAW), a dedicated analytical and radiochemical laboratory and supporting facilities to convert radioactive tank wastes into glass for long-term storage or final disposal.

The TOC will be responsible for WTP operations and decommissioning. The ORP defined the interface between the two major contractors in a series of interface documents. The primary waste interface document is 24590-WTP-ICD-MG-01-019, Rev. 4, ICD-19-Interface Control Document (ICD) for Waste Feed. Iterative updates to 24590-WTP-ICD-MG-01-019 are anticipated as new information is generated.

The current RPP baseline plan (ORP-11242, Rev 5) assumes deployment of a supplemental treatment capability, with net capacity calculated such that LAW treatment does not drive the mission duration (approximately $60 \%$ of the LAW tank waste). The addition of a supplemental treatment capability, including pretreatment (if needed) and immobilization, results in a system where HLW treatment capacity is the exclusive driver for completion of the RPP mission. Without additional LAW treatment capacity, the mission would extend an additional 40 years beyond fiscal year (FY) 2047. 
RPP-RPT-50122

Figure 1-1 depicts the Supplemental Treatment Project configured to be deployed in the tank farms.

Figure 1-1. Simplified Supplemental Treatment Flow Diagram

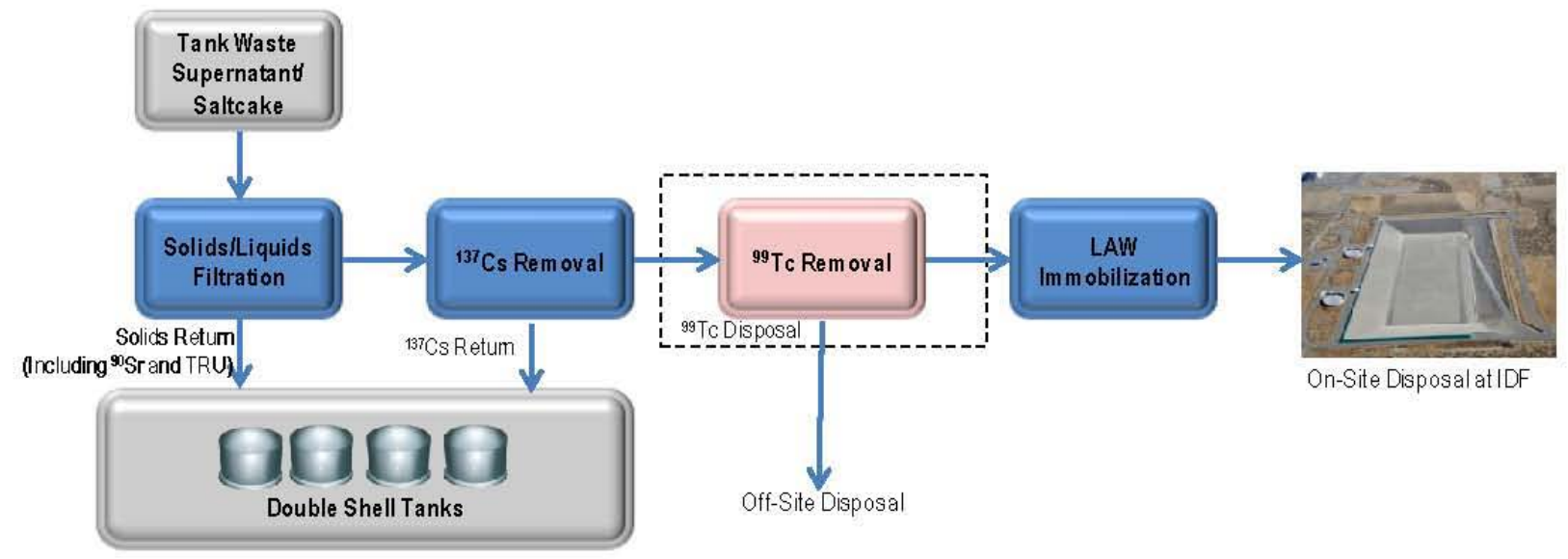

Supplemental treatment refers to the pretreatment of supernatant (liquid) wastes from the doubleshell tanks (DSTs), including dissolved saltcake retrieved from SSTs to the DSTs. Supplemental treatment includes two basic unit operations. The first operation removes insoluble constituents including actinides and strontium $90\left({ }^{90} \mathrm{Sr}\right)$. The separated solids will then follow the HLW treatment pathway. The second operation removes soluble cesium (focused on ${ }^{137} \mathrm{Cs}$ ) from the liquid wastes. Provided the degree of removal of the actinides, ${ }^{90} \mathrm{Sr}$, and ${ }^{137} \mathrm{Cs}$ is sufficient, the wastes can be solidified as immobilized LAW (ILAW). A Waste Incidental to Reprocessing (WIR) determ ination per DOE Manual 435.1-1, Radioactive Waste Management Manual, will be required to classify the wastes as LAW.

The unit operations for tank farm LAW pretreatment are similar to those for LAW pretreatment in the WTP. In the WTP, however, wastes are fed back into the system rather than returned to the DSTs as they would be in the tank farm case. Supplemental treatment technologies currently under consideration include crossflow filtration, rotary microfiltration, elutable spherical resorcinol formaldehyde ion exchange, and non-elutable crystalline silicotitanate ion exchange.

The WRPS Immobilization Project (Project No. T4S05) is responsible for identifying and implementing a process flowsheet that immobilizes the LAW fraction of Hanford's SST and DST waste. The product of the flowsheet, ILAW, will be one of three waste forms:

- Borosilicate glass;

- Mineral and binder;

- Grout.

The DOE plans to dispose of Hanford's ILAW as a mixed low-level waste (MLLW) by land disposal. It is the DOE's responsibility to ensure a cost effective approach is implemented.

Following pretreatment, where the SST and DST wastes are split into LAW and HLW fractions, technetium $99\left({ }^{99} \mathrm{Tc}\right)$ will be the limiting component for long-term disposal performance for immobilized LAW. Reducing the ${ }^{99} \mathrm{Tc}$ loading of the LAW stream has a direct impact on the leachability index of the immobilization product and the potential to use technologies that have difficulty incorporating and/or retaining ${ }^{99} \mathrm{Tc}$. 
The goal of this ${ }^{99} \mathrm{Tc}$ sorption media review is to present information and references to aid in the selection of a sorption media for feasibility studies for a ${ }^{99} \mathrm{Tc}$ removal system. The review does not select a specific sorption media with the expectation that it will be implemented into a ${ }^{99} \mathrm{Tc}$ removal system. All work performed to date regarding the capture of ${ }^{99} \mathrm{Tc}$ has shown that only ${ }^{99} \mathrm{Tc}$ in the pertechnetate form, $\mathrm{TcO}_{4}{ }^{-}$(where ${ }^{99} \mathrm{Tc}$ is in the +7 (VII) valence state), can be captured via sorption.

Feed to the Immobilization Project facility(s) is planned to be split roughly equally between the WTP and an additional treatment facility, to be provided by the Treatment Project (WRPS Project No. T4S01). Immobilized LAW will be disposed at a near-surface disposal site, such as the Integrated Disposal Facility (IDF) at Hanford. Due to past waste handling practices, leaking SSTs and the mobility of ${ }^{99} \mathrm{Tc},{ }^{99} \mathrm{Tc}$ retention is a major factor in the selection of an ILAW form. All of the waste forms under investigation as ILAW forms benefit from ${ }^{99} \mathrm{Tc}$ removal.

Employment of a sorption media has been selected as the best technology for removal of ${ }^{99} \mathrm{Tc}$ from the LAW immobilization feed stream. The goal of this review is to:

- Define ${ }^{99} \mathrm{Tc}$ ion exchange sorption media selection criteria required for implementation, including;

- Characteristics;

- Weighting for each characteristic;

- Identify potential ion exchange media, separated into two categories;

- Elutable;

- Non-elutable;

- Evaluate and rank sorption media using the defined characteristics and corresponding weighting.

The results from this review will aid in the development of a preliminary ${ }^{99} \mathrm{Tc}$ removal flowsheet to support the four immobilization technologies and a preferred waste disposal option. 
RPP-RPT-50122

\section{BASICS OF SORPTION MEDIA, TECHNETIUM, LOW-ACTIVITY WASTE, AND COLUMNS}

This section contains basic information regarding the properties of sorption media and technetium.

\subsection{ION EXCHANGE / RESIN / SORBENT MEDIA / SORPTION MEDIA}

For the purpose of this report, all media will be referred to as sorption media, except in sections on specific sorption media. Terms such as "resin" and "ion exchange" have specific meaning to the chemical processing industry. Resin implies organic media; ion exchange implies the release of one ion from the surface of the media in coordination with the capture of another. In many cases, the media incorporates ions by adsorption, where no exchange of ions takes place. Therefore to facilitate a level discussion, a universal term will be used to describe the materials tested throughout the text -- "sorption media."

\subsubsection{Sorption Media Size}

Most sorption media are available in different size ranges, typically determined by the screening of the material through an upper bound mesh and a lower bound mesh. Table 2-1 aids in understanding media diameter verses mesh range.

Table 2-1. Reference Table for Conversion of Mesh Size to Inches or Micrometers

\begin{tabular}{|c|c|c|}
\hline \multirow{2}{*}{ Mesh Range } & \multicolumn{2}{|c|}{ Diameter of Particles } \\
\cline { 2 - 3 } & Inches & Micrometers \\
\hline $20-50$ & $0.0331-0.0117$ & $840-297$ \\
\hline $50-100$ & $0.0117-0.0059$ & $297-149$ \\
\hline $100-200$ & $0.0059-0.0029$ & $149-74$ \\
\hline $200-400$ & $0.0029-0.0015$ & $74-38$ \\
\hline minus 400 & $<0.0015$ & $<38$ \\
\hline
\end{tabular}

The size of the media used is important for two reasons: 1) the smaller the material, the greater the surface area available per unit volume; and 2) the smaller the media the higher the pressure drop through the column. Therefore size and pressure drop must be balanced. Uniformity of the size also plays a role in pressure drop, with columns containing beads with less variation in diameter and shape having less pressure drop across the column.

\subsection{ELUTABLE AND NON-ELUTABLE SORPTION MEDIA}

The disposal path for the ${ }^{99} \mathrm{Tc}$ will have a large influence in the sorption media chosen for use. The WTP planned to process ${ }^{99} \mathrm{Tc}$ through its HLW melter, requiring an elutable sorption media. SuperLig ${ }^{\circledR} 639$ was chosen. If the selected disposal path is a separate waste stream that will 
leave the ${ }^{99} \mathrm{Tc}$ on the sorption media, a non-elutable resin will be required. There are many

different scenarios for ${ }^{99} \mathrm{Tc}$ disposal. The final review of sorption media will be divided between elutable and non-elutable material.

\subsection{BATCH DISTRIBUTION COEFFICIENT AND COLUMN DISTRIBUTION RATIO}

The batch distribution coefficient $\left(\mathrm{K}_{\mathrm{d}}\right)$ is an equilibrium measure of the distribution of a chemical species between a solution and a solid sorbent material. The concentration of a sorbed species is difficult to define and determine. Therefore the coefficient is based on the solution being processed. The equation for $\mathrm{K}_{\mathrm{d}}$ can be found in Table 3-2.

The column-distribution value, $\lambda$, represents the capacity of the sorption media in volumes of feed per volume of media. It is the ratio of the equilibrium concentration of targeted analyte $\mathrm{TcO}_{4}^{-}$per unit volume on the sorption media to that in the equilibrated solution. For column load operations where kinetics are not limiting, $\lambda$ is approximately the number of bed volumes (BVs) processed when the concentration of $\mathrm{TcO}_{4}{ }^{-}$in the effluent of a sorption column reaches $50 \%$ of the feed concentration $\left(\mathrm{C} / \mathrm{C}_{0}=0.5\right)$; designated $\lambda_{50}$. The equation for $\lambda_{50}$ can be found in Table 3-2.

When comparing $\mathrm{K}_{\mathrm{d}}$ and $\lambda_{50}$ values between research experiments, differences in experimental conditions are critical to note. Some of the factors that influence results are:

- Concentration of the target species (analyte);

- Resin to liquid ratio;

- Valence state of target species;

- Solution temperature;

- Resin particle size (if it affects equivalents/liter);

- Contact time (if not confirmed to be at equilibrium);

- Speciation;

- Concentration of competing ions;

- Concentration of ligands and complexants;

- Analytical techniques;

- Batch variability of the sorption media;

- $\mathrm{pH}$.

In addition to these causes, the $\lambda_{50}$ value may not coincide with $50 \%$ breakthrough during a column performance test for several reasons:

- Column design;

- Elution method;

- Flow rate;

- Sampling method; 
- Solution density;

- Sorption media particle size.

Unfortunately the result of the variation in $\mathrm{K}_{\mathrm{d}}$ and $\lambda_{50}$ values with process parameters is such that comparison of sorbent media between differing experiments is difficult. Column design and operation will need to be robust enough to handle the broad spectrum of Hanford's LAW feed batches.

\subsection{LOW-ACTIVITY WASTE FEED ENVELOPES}

The WTP contract divides LAW into three types of feed, or envelopes. Much of the testing performed on sorbent media refers to the material tested in terms of its feed envelope classification. A very brief description of each feed type follows. (A more in-depth description can be found in 24590-WTP-RPT-PT-02-005, Rev 5, Flowsheet Bases, Assumptions, and Requirements.)

- LAW Envelope A: Tank waste supernatant requiring solids/liquid separation and Cs removal to meet the LAW glass specification.

- LAW Envelope B: Higher concentrations of Cs than envelope A or C. Also may contain higher levels of chlorine $(\mathrm{Cl})$, chromium $(\mathrm{Cr})$, iron $(\mathrm{F})$, sulfate $\left(\mathrm{SO}_{4}\right)$, and phosphate $\left(\mathrm{PO}_{4}\right)$.

- LAW Envelope C: Contains organically complexed ${ }^{90} \mathrm{Sr}$ and transuranic (TRU) waste requiring removal to meet the LAW glass specification. (These have been found to coincidentally contain substantial amounts of soluble ${ }^{99} \mathrm{Tc}$ that is not in the pertechnetate form.)

A supplemental immobilization facility will not likely divide LAW feeds in these same categories. Wastes high in organics will likely have a more selective processing path, e.g., all of them may be processed through the WTP LAW Vitrification facility or blended to meet feed requirements as a means of mitigating the presence of organics and ${ }^{99} \mathrm{Tc}$ IV.

\subsection{POTENTIAL AND PH EFFECT ON TECHNETIUM SPECIES}

The Eh-pH diagam presented in Figure 2-1 indicates the species of Tc encountered over a $\mathrm{pH}$ range of 0 to $13^{+}$, and over the electropotential range of $-0.8 \mathrm{~V}$ to $1.2 \mathrm{~V}$, versus standard hydrogen electrode. Those Tc species that are solid are in bold and noted with ( $\mathrm{cr}=$ crystalline). 
From previous electrochemical corrosion studies, the open circuit potential of the Hanford SSTs and DSTs are in the cathodic range (from -229 to $400 \mathrm{mV}$ vs. SCE) ${ }^{1}$ and they have a $\mathrm{pH}$ range between 13 and $14^{+}$. According to Figure 2-1, the Tc species that the sup ernate accommodate are soluble (red shaded area) and predominately $\mathrm{TcO}_{4}^{-}$, with some $\mathrm{Tc}(\mathrm{V})$ oxy-hydroxide $\left(\mathrm{TcO}(\mathrm{OH})_{3}{ }^{-}\right)$. Other oxidation states of ${ }^{99} \mathrm{~T} \mathrm{c} \mathrm{have} \mathrm{been} \mathrm{reported} \mathrm{in} \mathrm{the} \mathrm{complexant} \mathrm{concentrate}$ tanks, 241-AN-102 and 241-AN-106, designated Env elope C for WTP feed. It is beyond the scope of this study to elucidate the oxidative approach to destroy the complexant concentrate organics to drive non-pertechnetate species to the pertechnetate state.

\section{Figure 2-1. T echnetium Species (Guillaumont, et al, 2003) ${ }^{2}$}

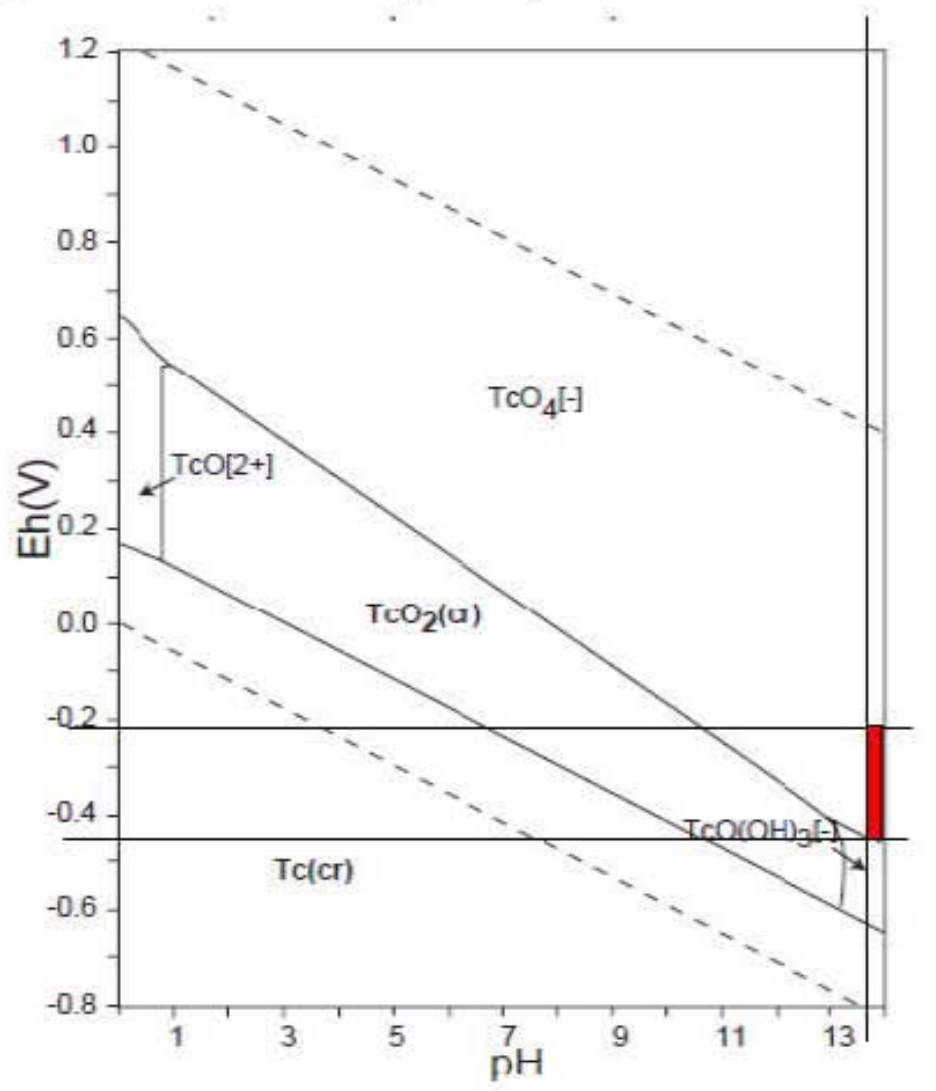

\footnotetext{
${ }^{1}$ RPP-RP T -38319, Rev 0, Electrochemical Corrosion Tests for Tank 241-AP-105 Supermate Using Grab Samples 5AP-07-01, \%AP-07-02A, 5AP-07-03A, and 5AP-07-04A, October 2008, andRPP-RPT-34697, Rev. 0, elec trochemic al Corrosion Report for Tanks 241-AW-103, 241-AZ-102, 241-AN-106, 241-AN-107, 241-A Y-101, and 241-A Y-1025, August 2007, CH2M HILL Hanford Group, Inc., Richland, Washington.

${ }^{2}$ Presented in Atlas of Eh-pH Diagrams, Intercomparison of Thermodynamic Databases, Geological Survey of Japan Open File Report No. 419, National Institute of Advanced Industrial Science and Technology, Research Center for Deep Geological Environments, Naoto TAKENO, May, 2005.
} 
RPP-RPT-50122

\section{IMMOBILIZATION SORPTION MEDIA EVALUATION CRITERA}

Technetium removal from treated LAW is expected to be a one-step ion exchange process. Treated LAW will be stored as it exits WTP Pretreatment and the Supplemental Treatment Project facilities, then fed through ion exchange columns and into an immobilization feed $\operatorname{tank}(\mathrm{s})$.

Immobilization has assumed feed vector batches are based on the HTWOS run documented in SFV-2000, FeedVectorWTP Realignment AOff BEL Gen-6.1-8.40-2010-0-07-at-15-14-1ll.xlsx. The feed composition review, Table 3-1, was performed using SVF-2023, Immobilization System Hazard Category Source Term for Pre-Conceptual Candidate Technologies. The concentrations listed in Table 3-1are by batch. For example, feed batch 103 has the highest concentration of ${ }^{99} \mathrm{Tc}$ at $1.2 \times 10^{-4}$ moles/liter. Table $3-1$ also contains feed parameters as outlined in RPP-SPEC48094, Rev 0, Immobilization Project Facility System Specification. Only cations and anions of most concern are listed in Table 3-1.

Table 3-1. Feed Composition Properties

\begin{tabular}{|c|c|c|c|c|c|}
\hline \multicolumn{7}{|c|}{ COMPOSITION (SVF-2023, by feed batch) } \\
\hline ANALYTES & UNITS & MAXIMUM & MINIMUM & MEDIAN & AVERAGE \\
\hline${ }^{99} \mathrm{Tc}$ & g-moles/liter & $1.20 \mathrm{E}-04$ & $4.36 \mathrm{E}-06$ & $2.33 \mathrm{E}-05$ & $3.85 \mathrm{E}-05$ \\
\hline $\mathrm{Al}^{+3}$ & g-moles/liter & $1.47 \mathrm{E}+00$ & $3.98 \mathrm{E}-02$ & $2.51 \mathrm{E}-01$ & $3.71 \mathrm{E}-01$ \\
\hline $\mathrm{K}^{+}$ & g-moles/liter & $7.75 \mathrm{E}-01$ & $3.60 \mathrm{E}-03$ & $2.22 \mathrm{E}-02$ & $5.95 \mathrm{E}-02$ \\
\hline $\mathrm{Na}^{+}$ & g-moles/liter & $9.40 \mathrm{E}+00$ & $9.58 \mathrm{E}-01$ & $3.98 \mathrm{E}+00$ & $5.53 \mathrm{E}+00$ \\
\hline $\mathrm{NO}_{2}^{-}$ & g-moles/liter & $1.88 \mathrm{E}+00$ & $1.42 \mathrm{E}-01$ & $5.85 \mathrm{E}-01$ & $8.66 \mathrm{E}-01$ \\
\hline $\mathrm{NO}_{3}^{-}$ & g-moles/liter & $4.03 \mathrm{E}+00$ & $4.90 \mathrm{E}-01$ & $1.67 \mathrm{E}+00$ & $2.32 \mathrm{E}+00$ \\
\hline $\mathrm{OH}^{-}$ & g-moles/liter & $9.02 \mathrm{E}+00$ & $1.77 \mathrm{E}-01$ & $9.77 \mathrm{E}-01$ & $1.43 \mathrm{E}+00$ \\
\hline $\mathrm{PO}_{4}^{-3}$ & g-moles/liter & $3.62 \mathrm{E}-01$ & $1.40 \mathrm{E}-02$ & $6.76 \mathrm{E}-02$ & $1.04 \mathrm{E}-01$ \\
\hline $\mathrm{SO}_{4}^{-2}$ & g-moles/liter & $3.68 \mathrm{E}-01$ & $1.39 \mathrm{E}-02$ & $6.46 \mathrm{E}-02$ & $9.90 \mathrm{E}-02$ \\
\hline \multicolumn{7}{|c|}{ GENERAL PROPERTIES (RPP-SPEC-48094) } \\
\hline Instantaneous Throughput * \\
\hline Nominal Throughput * \\
\hline pH
\end{tabular}

* Throughput is on a sodium $(\mathrm{Na})$ basis. 
Criteria for sorption media selection for use in the immobilization facility will need to account for four major categories: 1) technical performance, 2) cost, 3) schedule, and 4) safety and environmental impact. The criteria outlined in this section capture what is known about the sorption media selected for further review. Most of the information concerns technical development of each media, and can be used to evaluate the feasibility of implementing sorption media for ${ }^{99} \mathrm{Tc}$ removal.

Criteria impacting cost and schedule that DOE must consider, such as the ability to source the material and establish an intellectual property agreement to ensure that manufacture of the sorption media is possible at more than one facility, are not covered in this review since adequate information is not available and vendor reviews are not applicable to technical feasibility. Table 3-2 and Table 3-3 show parameters important to selection of sorption media and Hanford LAW feed characteristics critical for ensuring testing performed by a reference is applicable to the Immobilization Project. Criteria listed in Table 3-3 can be used to quickly evaluate the applicability of solutions used to test sorption media against Hanford's LAW.

\section{Table 3-2. Criteria for Evaluation of Sorbent Media}

\section{CHARACTERISTIC}

Ability to supply amounts of $\geq$ $2000 \mathrm{lbs}$

BV per Hour Operation

Sorption media Cost per Pound (or $\mathrm{ft}^{3}$ )

Cost per $\mathrm{Ci}^{99} \mathrm{Tc}$ Removed

Elutable (loading cycles)

Equivalents/L

Storage, Shelf Life, \& Handling Specifications

\section{DESCRIPTION}

The DOE must have the ability to procure sorption media for a long period of time. To ensure this the ability to have an intellectual property (IP) agreement with the vendor will be required or the equivalent material must be commercially available via multiple suppliers.

Implementation requirement that will be needed to size the ion exchange column(s).

The cost of sorption media consumed is an important factor for sorption media selection. Elutable sorption media will be able to factor in the number of cycles the sorption media may be regenerated to offset procurement costs.

The total system cost; implementation costs for all aspects of ${ }^{99} \mathrm{Tc}$ removal need to be considers.

Depending on the ${ }^{99} \mathrm{Tc}$ disposal route chosen, whether the sorption media is elutable or non-elutable may be the most critical property of the sorption media.

- Non-elutable sorption media need to tightly bind ${ }^{99} \mathrm{Tc}$ and not release it except under extreme conditions or long contact times.

- Elutable sorption media need to employ an eluent that is safe to implement and produce $\mathrm{a}^{99} \mathrm{Tc}$ solution that is easily processed further into an immobilized waste form. The number of loading cycles (times the sorption media can be recharged) will also be a critical implementation factor.

The number of active reactant sites available for $\mathrm{TcO}_{4}{ }^{-}$capture will influence the size of the column required.

Typically sorption media have a long storage and shelf life. Some sorption media require storage at low temperature and corrosive solutions.

The physical stability of sorption media is affected by the method of product handling. Deep sorption media beds, small diameter beds, high flow rates and agitation/frequent pumping contribute to sorption media degradation and breakage.

$\mathrm{K}_{\mathrm{d}}[\mathrm{Tc}]$ $K_{d}=\left(\left(T_{i}-T_{f}\right) / T_{f}\right) \times(V /(M \times F))$ 


\begin{tabular}{|c|c|}
\hline CHARACTERISTIC & DESCRIPTION \\
\hline & 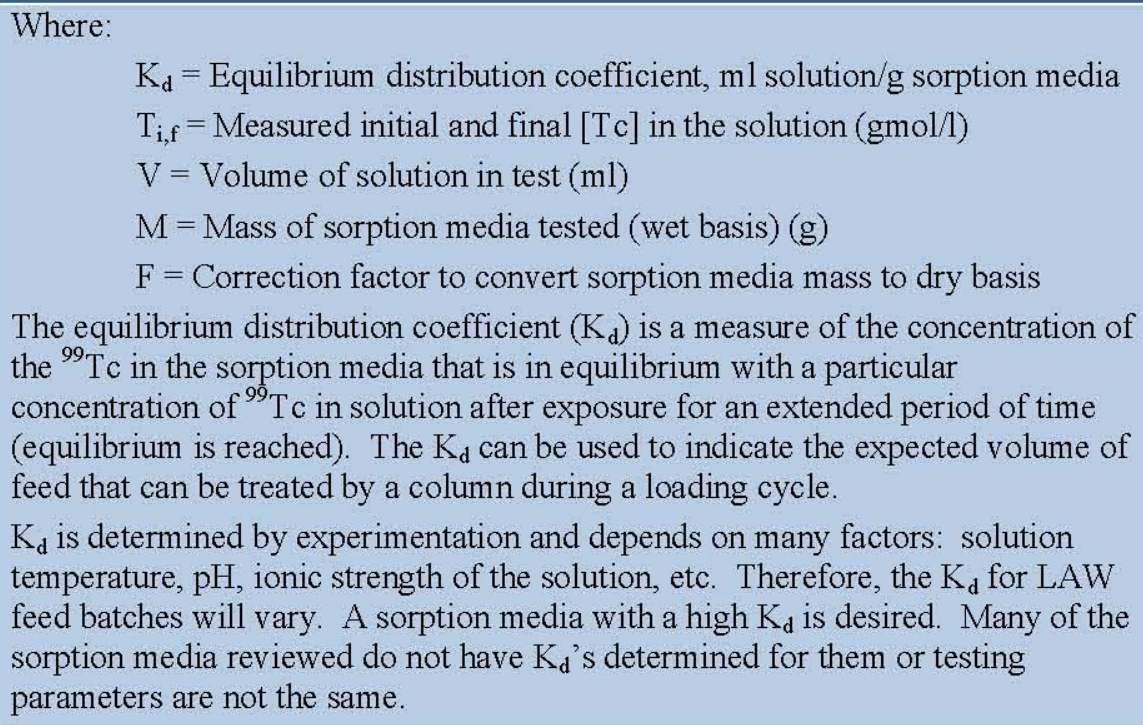 \\
\hline$\lambda_{50}$ & $\begin{array}{l}\text { The column distribution ratio is the batch distribution coefficient converted from } \\
\text { mass to volume. The value obtained is roughly the number of } \mathrm{BV} \text { that can be } \\
\text { passed through the column prior to } 50 \% \text { breakthrough of the targeted analyte. } \\
\begin{aligned} \lambda_{50(\mathrm{Tc})}= & \left(\mathrm{K}_{\mathrm{d}}\right)\left(\rho_{\mathrm{b}}\right) \\
& \lambda_{50(\mathrm{Tc})}=\text { the column distribution ratio for }{ }^{99} \mathrm{Tc} \text {, volume feed per volume } \\
& \text { sorption media (ml solution } / \mathrm{ml} \text { sorption media) } \\
& \mathrm{K}_{\mathrm{d}}=\text { Equilibrium distribution coefficient, } \mathrm{m} 1 \mathrm{~g} \text { sorption media } \\
& \rho_{\mathrm{b}}=\text { the bulk density of the sorption media }(\mathrm{g} / \mathrm{ml}) \text { in the solution (or } \\
& \sim \text { the bulk dry density adjusted for swelling) }\end{aligned}\end{array}$ \\
\hline Organic & $\begin{array}{l}\text { Sorption media parameter that is not important for implementation in the ion } \\
\text { exchange column, but could be critical depending on the disposal path chosen for } \\
\text { the }{ }^{99} \mathrm{Tc} \text {. }\end{array}$ \\
\hline Particle Size & $\begin{array}{l}\text { Sorption media performance parameter. Solute adsorption kinetics or speed } \\
\text { generally increase as particle size decreases, however pressure drop through the } \\
\text { ion exchange column increase as particle size decreases. }\end{array}$ \\
\hline $\mathrm{pH}$ operating range & LAW will be fed at high $\mathrm{pH}(\geq 12)$. \\
\hline Poisons & $\begin{array}{l}\text { Anions, cations, molecules, and elements that occupy or prevent the occupation } \\
\text { of sorption media active sites from being occupied by } \mathrm{TcO}_{4}^{-} \text {. }\end{array}$ \\
\hline Preparation Procedure & Method used process the sorption media from a stored stated to active state. \\
\hline $\begin{array}{l}\text { Radiological Stability and/or } \\
\text { Gas Generation }\end{array}$ & $\begin{array}{l}\text { Effects of radiation on the sorption media; often results in the evolution of gas, } \\
\text { typically } \mathrm{H}_{2} \text {, which poses a safety hazard. Since }{ }^{99} \mathrm{Tc} \text { removal will be performed } \\
\text { following filtering (removal of most }{ }^{90} \mathrm{Sr} \text { ) and } \mathrm{Cs} \text { ion exchange, this } \\
\text { characteristic should not be a determining factor for sorption media selection. }\end{array}$ \\
\hline $\begin{array}{l}\text { Sorption media Density (weight } \\
\text { per unit volume) }\end{array}$ & $\begin{array}{l}\text { Ion exchange column configuration and design will be influenced on the } \\
\text { buoyancy of the sorption media in the feed solution. }\end{array}$ \\
\hline Sorption media Disposal Route & $\begin{array}{l}\text { Will be dependent on the }{ }^{99} \mathrm{Tc} \text { disposal route chosen. If an elutable sorption } \\
\text { media is selected then most likely the sorption media will be disposed of as a } \\
\text { Class A type waste. If a non-elutable sorption media is chosen then the method } \\
\text { of immobilization will dictate the sorption media disposal path. }\end{array}$ \\
\hline
\end{tabular}




\begin{tabular}{|c|c|}
\hline CHARACTERISTIC & DESCRIPTION \\
\hline Selectivity to ${ }^{99} \mathrm{Tc}$ & $\begin{array}{l}\text { Affinity of the sorption media to pull }{ }^{99} \mathrm{Tc} \text { out of the feed solution. It will vary } \\
\text { based on feed ionic strength, poisons, feed temperature, and flow rate of the feed } \\
\text { through the sorption media. }\end{array}$ \\
\hline $\begin{array}{l}\text { Stability of Spent Sorption } \\
\text { media }\end{array}$ & $\begin{array}{l}\text { The ability of the sorption media to not break down and strongly bind the Tc to } \\
\text { its matrix is most important for a non-elutable. }\end{array}$ \\
\hline Tc Disposal Route & $\begin{array}{l}\text { The selected sorption media will need to support the selected }{ }^{99} \mathrm{Tc} \text { disposal path, } \\
\text { examples are: } \\
\text { - Incorporation into HLW glass via vitrification } \rightarrow \text { elutable or non-elutable } \\
\text { sorption media could be chosen. } \\
\text { - Disposed of in a grout matrix } \rightarrow \text { non-elutable sorption media required. }\end{array}$ \\
\hline Temperature operating range & $\begin{array}{l}\text { The LAW feed may need to be feed to the ion exchange media at elevated } \\
\text { temperatures to minimize precipitation. Implementation of sorption media that } \\
\text { enables a robust operating range is desirable. }\end{array}$ \\
\hline $\begin{array}{l}\text { Technology Readiness Level } \\
\text { (TRL) }\end{array}$ & $\begin{array}{l}\text { Many sorption media will remove } \mathrm{TcO}_{4}^{-} \text {from solution. For this review, those } \\
\text { having proved their ability to perform well for Hanford SST and DST wastes will } \\
\text { be assumed to require less process development. }\end{array}$ \\
\hline
\end{tabular}

\section{Table 3-3. Ion Exchange Feed Solution Applicability Criteria ${ }^{a}$}

\begin{tabular}{|l|l|}
\hline \multicolumn{1}{|c|}{ PARAMETER } & \multicolumn{1}{c|}{ VALUE } \\
\hline Test Material & $\begin{array}{l}\text { DOE tank waste or simulant (not necessarily Hanford } \\
\text { tank waste) }\end{array}$ \\
\hline Salt Content & $\geq 3$ molar Na \\
\hline $\mathrm{pH}$ & $\geq 12$ \\
\hline Target Analyte & ${ }^{99} \mathrm{Tc}(\mathrm{VII})$ or $\mathrm{Re}(\mathrm{VII})$ (Rhenium) used \\
\hline Target Analyte Concentration & $4.36 \mathrm{E}-07<\left[{ }^{99} \mathrm{Tc}\right]$ or $[\mathrm{Re}]<1.20 \mathrm{E}-03$ \\
\hline $\begin{array}{l}\text { Note: } \\
\text { Hanfesting on simulants or wastes outside the criteria listed here is too far from the waste feed matrix from } \\
\text { Hanford SST and DST waste to be considered as relevant. }\end{array}$
\end{tabular}

Many of these criteria are not part of typical vendor specification sheets. Deploying ion exchange media for industrial applications requires testing to understand interactions between feed and sorption media, acquire meaningful decontamination factor (DF) values and understand poisons, gas generation, selectivity, eluent efficiency and loading. A much more inclusive set of information is required for final sorption media selection; see Table 3-4. However a total system review is not part of this report.

Factors most influential for economics for the system are cost of the sorption media, volume of treated waste before media disposal, cost for disposal of the sorption media and the ${ }^{99} \mathrm{Tc}$, costs for disposition of storage/preparation/eluent chemicals and research required to achieve the required TRL level for conceptual design. 
The implemented system also must provide a safe work environment that minimizes safety risks due to mechanical, chemical and radiological exposure, and minimize impacts to the environment. Important sorption media parameters affecting safety and environment are storage, handling, preparation and regeneration (eluent) chemicals. Gas generation from radiolysis should be minimal due to the removal of ${ }^{90} \mathrm{Sr}$ and ${ }^{137} \mathrm{Cs}$ from the feed stream. Co-absorption of other analytes (e.g. Chromium or actinides) could also impact the selection of a disposal path.

Key technical parameters examined for this report are those critical for ensuring a ${ }^{99} \mathrm{Tc}$ removal system using ion exchange is technically feasible. Most critical features for the sorption media will ensure ${ }^{99} \mathrm{Tc}$ removal targets can be met on Hanford SST and DST wastes. Vendor experience with feeds similar to tank waste is minimal, and testing sorption media with simulants can result in under- or over-estimating a sorption media's ability to perform in a complex, concentrated high $\mathrm{pH}$ feed. Therefore results from tests performed with tank waste weigh heavily on estimating the technical maturity of a given sorption media.

Table 3-4. Sorption Media Characteristics Required for a more In-Depth Evaluation

\section{CRITERIA FOR A CRITICAL REVIEW OF SORPTION MEDIA}

\section{ECONOMICS}

- Cost per $\mathrm{Ci}^{99} \mathrm{Tc}$ Removed (for the system)

- Sorption media Cost

- Ability to Source Sorption media

- $\quad$ Sorption media Disposal Route

- Stability of Spent Sorption media

- $\quad$ Storage, Shelf Life

- Structure and Composition not a Trade Secret

- Tc Disposal Route

\section{SAFET YENVIRONMENTAL}

- Eluant

- Gas Generation

- Handling Specifications

- Preparation Procedure

- Radiolysis

- Co-adsorbed analytes

\section{TECHNICAL}

- BV per Hour

- $\mathrm{K}_{\mathrm{d}}\left[{ }^{99} \mathrm{Tc}\right]\left(\mathrm{Tc} \mathrm{c}^{99}\right.$ removal efficiency)

- Type of sorption media (organic vs. inorganic)

- Loading Cycles

- Temperature Operating Range

- Poisons

- Preparation Procedure

- Radiolysis

- Sorption media Disposal Route

- Selectivity to ${ }^{99} \mathrm{Tc}$

- $\quad{ }^{99} \mathrm{Tc}$ Disposal Route

- $\mathrm{pH}$ Range

- $\quad{ }^{99}$ Tc Loading (moles ${ }^{99} \mathrm{Tc}$ per unit volume of sorption media)

- Technical Maturity 


\subsection{ION EXHANGE / SORBENT MEDIA}

Table 3-5 lists media that have been identified as possible ${ }^{99} \mathrm{Tc}$ removal candidates from past reports or a current literature search. The list does not include all potential sorption media, but lists those having potential to meet the Immobilization Project's requirements. An initial screening of media was performed to narrow the list of sorption media to those having the highest likelihood of success. Sorption media were screened on their ability to perform in a solution as characterized in Table 3-1. Those that have been successfully tested for removal of ${ }^{99} \mathrm{Tc}$ from Hanford's waste were carried forward as recommended by subject matter experts (SMEs). Review results from a 2002 WTP review were also considered ${ }^{3}$. The WTP review based sorption media recommendations on the ability of the media to meeting four criteria:

1. The resin(s) must be chemically and structurally stable over their expected operational lifetime when in contact with the waste feed envelope definitions.

2. The defined structure and composition of the selected resin(s) shall not be a trade secret.

3. The selected resin(s) shall have been manufactured by a supplier of demonstrated ability (greater than 1 percent of expected annual need but not less than 75 gal).

4. The selected resin(s) shall have been demonstrated on simulated or actual alkaline (greater than 1.OM hydroxide), high ionic strength wastes.

The WTP review led to the down-select of three resins - ABEC, Dowex 1x8, and Reillex HPQ -

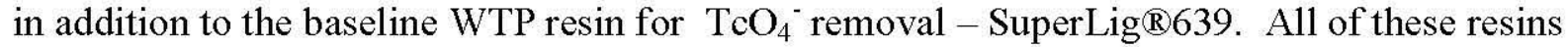
have been tested with Hanford tank waste.

Table 3-5. Ion Exchange / Sorbent Media Initial Screening Results

\begin{tabular}{|c|c|}
\hline $\begin{array}{c}\text { ION EXCHANGE / } \\
\text { SORBENT MEDIA }\end{array}$ & DISPOSITION \\
\hline ABEC 2000 & Selected for Review \\
\hline ABEC 5000 & $\begin{array}{c}\text { Not Selected for Review } \\
\text { (vendor recommendation) }\end{array}$ \\
\hline $\begin{array}{c}\text { Activated Carbon } \\
\text { Not Selected for Review } \\
\text { (WTP screening) }\end{array}$ \\
\hline $\begin{array}{c}\text { Aliquat } \\
\text { (tricaprylmethylammonium } \\
\text { chloride) }\end{array}$ & $\begin{array}{c}\text { Not Selected for Review } \\
\text { (WTP screening) }\end{array}$ \\
\hline $\begin{array}{c}\text { Amberlite IRA-400 } \\
\text { Not Selected for Review } \\
\text { (SEM) }\end{array}$ \\
\hline
\end{tabular}

\begin{tabular}{|c|c|}
\hline $\begin{array}{c}\text { ION EXCHANGE / } \\
\text { SORBENT MEDIA }\end{array}$ & DISPOSITION \\
\hline IONSIV IE-910 & $\begin{array}{c}\text { Not Selected for Review } \\
\text { (SME) }\end{array}$ \\
\hline Iron Sulfide & $\begin{array}{c}\text { Not Selected for Review } \\
\text { (WTP screening) }\end{array}$ \\
\hline $\begin{array}{c}\text { Kurion TAM } \\
\text { (Sn }\end{array}$ & $\begin{array}{c}\text { Apatite Sorption } \\
\text { media) }\end{array}$ \\
\hline $\begin{array}{c}\text { Selected for Review } \\
\text { LANL - TiO2/carbon } \\
\text { beads }\end{array}$ & $\begin{array}{c}\text { Not Selected for Review } \\
\text { (WTP screening) }\end{array}$ \\
\hline $\begin{array}{c}\text { Prolite A-520E } \\
\text { Selected for Review }\end{array}$ \\
\hline
\end{tabular}

\footnotetext{
3 24590-PTF-RPT-RT-02-001, Rev 0, WTP PTF Alternative Resin Selection, Bechtel National, Inc., Richland, Washington, 2002.
} 


\begin{tabular}{|c|c|}
\hline $\begin{array}{l}\text { ION EXCHANGE / } \\
\text { SORBENT MEDIA }\end{array}$ & DISPOSITION \\
\hline Amberlite IRA-904 & $\begin{array}{l}\text { Not Selected for Review } \\
\text { (SME) }\end{array}$ \\
\hline Amberlite XE-238 & $\begin{array}{c}\text { Not Selected for Review } \\
\text { (WTP screening) }\end{array}$ \\
\hline $\begin{array}{c}\text { Azaphosphane-based } \\
\text { media }\end{array}$ & $\begin{array}{c}\text { Not Selected for Review } \\
\text { (WTP screening) }\end{array}$ \\
\hline Bio-Rad AG 1-x8 & $\begin{array}{l}\text { Not Selected for Review } \\
\text { (SME) }\end{array}$ \\
\hline Bio-Rad MSZ-1 & $\begin{array}{l}\text { Not Selected for Review } \\
\text { (WTP screening) }\end{array}$ \\
\hline BiQuat RO-02-119 & $\begin{array}{l}\text { Not Selected for Review } \\
\text { (WTP screening) }\end{array}$ \\
\hline BiQuat VP-02-217 & $\begin{array}{c}\text { Not Selected for Review } \\
\text { (WTP screening) }\end{array}$ \\
\hline $\begin{array}{l}\text { Boehmite, synthetic } \\
\text { aluminum oxyhydroxide } \\
\text { gel }\end{array}$ & $\begin{array}{c}\text { Not Selected for Review } \\
\text { (WTP screening) }\end{array}$ \\
\hline $\begin{array}{l}\text { Cross-linked Polyvinyl } \\
\text { Pyridine }\end{array}$ & $\begin{array}{l}\text { Not Selected for Review } \\
\text { (WTP screening) }\end{array}$ \\
\hline Crypt-DER & $\begin{array}{c}\text { Not Selected for Review } \\
\text { (WTP screening) }\end{array}$ \\
\hline Dowex 1X8 & Selected for Review \\
\hline Dowex $2 X 8$ & $\begin{array}{c}\text { Not Selected for Review } \\
\text { (WTP screening) }\end{array}$ \\
\hline Duolite CS-100 & $\begin{array}{l}\text { Not Selected for Review } \\
\text { (SME) }\end{array}$ \\
\hline Forager Sponge & $\begin{array}{c}\text { Not Selected for Review } \\
\text { (WTP screening) }\end{array}$ \\
\hline
\end{tabular}

\begin{tabular}{|c|c|}
\hline $\begin{array}{l}\text { ION EXCHANGE / } \\
\text { SORBENT MEDIA }\end{array}$ & DISPOSITION \\
\hline Prolite A-530E & Selected for Review \\
\hline Prolite A-532E & $\begin{array}{l}\text { Not Selected for Review } \\
\text { (SME) }\end{array}$ \\
\hline Reillex 402 & $\begin{array}{c}\text { Not Selected for Review } \\
\text { (WTP screening) }\end{array}$ \\
\hline Reillex HP & $\begin{array}{c}\text { Not Selected for Review } \\
\text { (WTP screening) }\end{array}$ \\
\hline Reillex-HPQ & Selected for Review \\
\hline Sr-SPEC & $\begin{array}{l}\text { Not Selected for Review } \\
\text { (WTP screening) }\end{array}$ \\
\hline SuperLig 639 & Selected for Review \\
\hline Sybron Ionac Sr-3 & $\begin{array}{c}\text { Not Selected for Review } \\
\text { (WTP screening) }\end{array}$ \\
\hline Sybron Ionac SR-6 & $\begin{array}{l}\text { Not Selected for Review } \\
\text { (WTP screening) }\end{array}$ \\
\hline Sybron Ionic SR-7 & $\begin{array}{l}\text { Not Selected for Review } \\
\text { (SME) }\end{array}$ \\
\hline TEVA & $\begin{array}{l}\text { Not Selected for Review } \\
\text { (WTP screening) }\end{array}$ \\
\hline TRU-SPEC & $\begin{array}{c}\text { Not Selected for Review } \\
\text { (WTP screening) }\end{array}$ \\
\hline $\begin{array}{l}\text { Zero-valence Iron } \\
\text { filings/beads }\end{array}$ & $\begin{array}{c}\text { Not Selected for Review } \\
\text { (WTP screening) }\end{array}$ \\
\hline- & - \\
\hline
\end{tabular}




\subsection{SORPTION MEDIA INFORMATION}

The following tables contain information on sorption media selected as candidates for the feasibility study. Several of the characteristics listed in Table 3-6 are unknown and therefore not listed in the sorption media property tables. For example, ${ }^{99} \mathrm{Tc}$ disposal routes can have many different paths and costs. Characteristics not carried forward to the sorption media properties review are:

- Cost of the system per $\mathrm{Ci}^{99} \mathrm{Te}$ removed;

- Trade status of structure and composition.

Many of the characteristics were binned in more than one of the three categories (economic, safety and technical). For the properties table, these characteristics have been placed in the bin most impacted. 
Table 3-6. Sorption Media Properties

\begin{tabular}{|c|c|c|c|c|c|c|c|}
\hline \multirow{2}{*}{$\begin{array}{c}\text { SORPTION } \\
\text { MEDIA } \\
\text { PROPERTY }\end{array}$} & \multirow[b]{2}{*}{ ABEC-2000® } & \multirow[b]{2}{*}{ DOWEX ${ }^{\circledR} 1-X 8$} & \multicolumn{2}{|c|}{ PUROLITE } & \multirow{2}{*}{$\begin{array}{l}\text { TAM - SnII Apatite } \\
\text { Microspheres } \\
\text { (Kurion, Inc.) }\end{array}$} & \multirow[b]{2}{*}{ REILLEX HPQ } & \multirow[b]{2}{*}{ SUPERLIG 639} \\
\hline & & & $\mathbf{A 5 2 0 E}$ & A530E & & & \\
\hline \multicolumn{8}{|l|}{ Economics } \\
\hline $\begin{array}{l}\text { Ability to supply } \\
\text { amounts of } \geq \mathbf{2 0 0 0} \\
\text { lbs }\end{array}$ & $\begin{array}{l}\text { Will require scale up } \\
\text { development but is a } \\
\text { technological possibility. (G) }\end{array}$ & & Yes (T) & Yes (T) & Yes (I) & Yes $(U)$ & Yes (B) \\
\hline $\begin{array}{l}\text { BV per Hour } \\
\text { Operation }\end{array}$ & Estimate $45-60 \mathrm{BV} / \mathrm{hr}(\mathrm{G})$ & & $\begin{array}{l}\text { Depends on } \\
\text { concentration of } \\
\text { competing anions }(T)\end{array}$ & $\begin{array}{l}\text { Depends on concentration } \\
\text { of competing anions }(\mathrm{T})\end{array}$ & Depends on application (I) & & $\begin{array}{l}99 \%{ }^{99} \mathrm{Tc} \text { removal for } 20 \% \text { of } \lambda_{50} \text { at } 3 \\
\text { BV } / \mathrm{hr} \text { in AP-101 (W) } \\
99 \%{ }^{99} \mathrm{Tc} \text { removal for } 43 \% \text { of } \lambda_{50} \text { at } 3 \\
\text { BV/hr in AZ-101 (Y) } \\
99 \%{ }^{99} \mathrm{Tc} \text { removal for } 40 \% \text { of } \lambda_{50} \text { at } 3 \\
\text { BV/hr in AW-101 (D) }\end{array}$ \\
\hline $\begin{array}{l}\text { Cost per Pound } \\
\left(\text { or } \mathrm{ft}^{3}\right)\end{array}$ & $\begin{array}{l}-30-60 \$ / \mathrm{bm} @ 0.8 \mathrm{~g} / \mathrm{ml} \\
(\sim 200-400 \$ \text { /gallon })(\mathrm{G})\end{array}$ & $\begin{array}{l}\text { Between } 160 \text { to } 186 \$ / 1 \mathrm{bm} \\
\text { (Q) and WRPS estimator }\end{array}$ & & $\begin{array}{l}-\$ 5.70 / \mathrm{lbm} @ 0.67 \mathrm{~g} / \mathrm{ml} \\
\left(\sim 238 / \mathrm{ft}^{3}\right)\end{array}$ & To be specified. (I) & $\begin{array}{l}-\$ 68 / \mathrm{lb} @ .88 \mathrm{~g} / \mathrm{ml} \\
(150 \$ / \mathrm{Kg})(\mathrm{U})\end{array}$ & $\begin{array}{l}\text { Vendor states that cost per lb is } \\
\text { dependent on volume and commercial } \\
\text { terms (V) }\end{array}$ \\
\hline Loading Cycles & $\begin{array}{l}\text { Estimate } 20 \text { loading cycles for } \\
\text { the resin but actual results will } \\
\text { depending on the effects of } \\
\text { radiolytic damage to the resin. } \\
\text { (G) }\end{array}$ & & $\begin{array}{l}\text { Single use disposable } \\
\text { resin (T) }\end{array}$ & $\begin{array}{l}\text { Single use disposable } \\
\text { resin (T) }\end{array}$ & Single use disposable resin (I) & & $\begin{array}{l}\text { Up to } 200 \text {, depending on radiation } \\
\text { exposure, but } \geq 50 \text { loading cycles } \\
\text { expected for LAW feed (V) }\end{array}$ \\
\hline Storage, Shelf Life & $\begin{array}{l}\text { Anticipate greater than } 2 \text { years of } \\
\text { shelf life under environmentally } \\
\text { controlled conditions. (G) }\end{array}$ & & 5 years $(\mathrm{T})$ & 5 years $(\mathrm{T})$ & Indefinite (I) & & 5-10 years, ambient air, dry or wet (V) \\
\hline \multicolumn{8}{|l|}{ Safety } \\
\hline Eluant & $\begin{array}{l}\text { Water, dilute saline or dilute acid } \\
\text { (G) }\end{array}$ & $\begin{array}{l}\text { 1) } 4 \mathrm{M} \mathrm{HNO}_{3}: 15 \mathrm{BV} \text {; } \\
0 \% \% \text { resiual } \mathrm{TC} \text { on resin } \\
\text { (A) } \\
\text { 2) } 1 \mathrm{M} \mathrm{NaOH}, 1 \mathrm{M} \\
\text { ethylene diamine, } 0.005 \mathrm{M} \\
\mathrm{Sn}(\mathrm{II}): 15 \mathrm{BV} ; \sim 0 \% \\
\text { residual }{ }^{99} \mathrm{Tc} \text { on resin(A) } \\
\text { 3) } 1 \mathrm{M} \mathrm{NaOH}, 0.1 \mathrm{M} \\
\text { ethylene diamine, } 0.01 \mathrm{M} \\
\mathrm{Sn}(\mathrm{II}): 15 \mathrm{BV} ; 25 \% \\
\text { residual }{ }^{99} \mathrm{Tc} \text { on resin (A) }\end{array}$ & Non-elutable (T) & Non-elutable (T) & Non-elutable (I) & $\begin{array}{l}8 \mathrm{MHNO}_{3}(\mathrm{~A}) \\
6 \mathrm{BV} \text { of } 1 \mathrm{M} \mathrm{NaOH}, 1 \mathrm{M} \text { ethylene } \\
\text { diamine, } 0.005 \mathrm{M} \mathrm{SnCl}_{2}(\mathrm{~A})(\mathrm{N})\end{array}$ & Water, optimal at $70^{\circ} \mathrm{C}(\mathrm{B})$ \\
\hline $\begin{array}{l}\text { Handling } \\
\text { Specifications }\end{array}$ & $\begin{array}{l}\text { Resin will shrink and swell up to } \\
30 \% \text { depending on ionic strength } \\
\text { of solutions passed through the } \\
\text { resin bed. (G) }\end{array}$ & & & & No special specs (I) & & $\begin{array}{l}\text { No special requirements - resin is } \\
\text { handled similarly to standard IX resin (B) }\end{array}$ \\
\hline Preparation & $\begin{array}{l}\text { ABEC@ resin should be } \\
\text { preconditioned with a basic }\end{array}$ & & $\begin{array}{l}\text { Backwash to classify } \\
\text { bed and then rinse }(\mathrm{T})\end{array}$ & $\begin{array}{l}\text { Backwash to classify bed } \\
\text { and then rinse (T) }\end{array}$ & $\begin{array}{l}\text { Sn II substitution for Ca in } \\
\text { Hydroxy Apatite (CaPO4) }\end{array}$ & & Hydrate in water for 30 minutes \\
\hline
\end{tabular}


RPP-RPT-50122

Table 3-6. Sorption Media Properties

\begin{tabular}{|c|c|c|c|c|c|c|c|}
\hline \multirow{2}{*}{$\begin{array}{l}\text { SORPTION } \\
\text { MEDIA } \\
\text { PROPERTY }\end{array}$} & \multirow[b]{2}{*}{ ABEC-2000® } & \multirow[b]{2}{*}{ DOWEX ${ }^{\circledR}$ 1-X8 } & \multicolumn{2}{|c|}{ PUROLITE } & \multirow{2}{*}{$\begin{array}{l}\text { TAM - SnII Apatite } \\
\text { Microspheres } \\
\text { (Kurion, Inc.) }\end{array}$} & \multirow[b]{2}{*}{ REILLEX HPQ } & \multirow[b]{2}{*}{ SUPERLIG 639} \\
\hline & & & A520E & A530E & & & \\
\hline Procedure & $\begin{array}{l}\text { solution of similar molarity prior } \\
\text { to loading waste solutions }(\mathrm{G})\end{array}$ & & & & $\begin{array}{l}\text { Microsphere production. Glass } \\
\text { substrate initiator. (I) }\end{array}$ & & \\
\hline $\begin{array}{l}\text { Radiological } \\
\text { Stability and/or } \\
\text { Gas Generation }\end{array}$ & $\begin{array}{l}\text { There is potential for } \mathrm{CO}_{2} \\
\text { evolution from radiolysis of the } \\
\text { resin }(\mathrm{G}) \\
\text { Small } \mathrm{K}_{\mathrm{d}} \text { reduction at } 130 \mathrm{M} \\
\text { Rads Irradiation (A) }\end{array}$ & $\begin{array}{l}16 \% \mathrm{~K}_{\mathrm{d}} \text { reduction at } 100 \mathrm{M} \\
\text { Rads Irradiation (A) }\end{array}$ & & & $\begin{array}{l}\text { Extreme rad stability. No } \\
\text { know gas generation. (I) }\end{array}$ & $\begin{array}{l}\text { Good Radiolytic Stability observed at } \\
\text { 1,000M Rads (A) }\end{array}$ & $\begin{array}{l}\text { Organic resin so does have potential for } \\
\text { gas generation, but providing Cs is } \\
\text { removed prior to } 99 \text { Tc removal, it will not } \\
\text { suffer any significant radiolytic } \\
\text { degradation resulting in gas generation } \\
\left(1 \times 10^{8} \mathrm{Rad}\right)(\mathrm{R})\end{array}$ \\
\hline \multicolumn{8}{|c|}{ Process Technical Parameters } \\
\hline Equivalents/L & $0.8 \mathrm{eq} / \mathrm{L}(\mathrm{G})$ & $\begin{array}{l}1.2 \mathrm{eq} / \mathrm{L}(\mathrm{Cl} ; \text {; by wetted } \\
\text { volume) }(\mathrm{F})\end{array}$ & $0.9 \mathrm{eq} / \mathrm{L} \min .(\mathrm{T})$ & $0.6 \mathrm{eq} / \mathrm{L} \min .(\mathrm{T})$ & $\sim 2.25-2.50 \mathrm{eq} / \mathrm{L}(\mathrm{I})$ & 4 eq $/ \mathrm{kg}$ dry $(U)$ & \\
\hline $\left.\mathrm{K}_{\mathrm{d}} \mathrm{l}^{99} \mathrm{Te}\right]$ & $\begin{array}{l}\text { Depends on concentrations of } \\
\text { other analytes, but improves with } \\
\text { higher concentration of anions } \\
\text { (G) } \\
141-160 \mathrm{ml} / \mathrm{g} \text { and } \lambda_{50} \\
\text { breakthrough as } 40-60 \mathrm{BV} \text { at } \\
10 \mathrm{BV} / \mathrm{hr} \text { (A) } \\
410 \mathrm{ml} / \mathrm{g} \mathrm{SY}-101 \text { waste (P) }\end{array}$ & $\begin{array}{l}\sim 12.3 \mathrm{mg}{ }^{99} \mathrm{Tc} \text { per } \mathrm{cm}^{3} \\
1850 \mathrm{ml} \text { solution } / \mathrm{g} \text { resin } \\
\text { (H) }\end{array}$ & 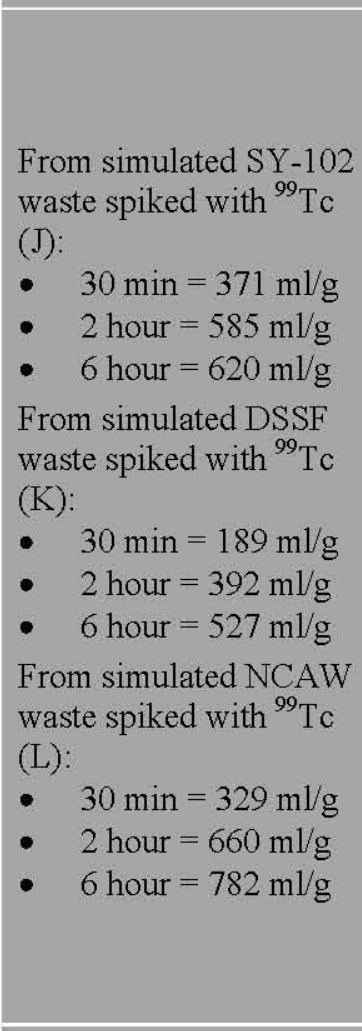 & $\begin{array}{l}49,879 \mathrm{ml} / \mathrm{g} \text { for ETF } \\
\text { waste matrix }(\mathrm{O})\end{array}$ & $\begin{array}{l}\text { pH } 8.6 \text { WTP Recycle } \\
\text { Surrogate: } 6.19 \mathrm{E}+01 \text { (I) } \\
\text { pH } 13.2 \text { At tank AN-104 } \\
\text { Surrogate: } 6.94 \mathrm{E}+02 \text { (I) }\end{array}$ & 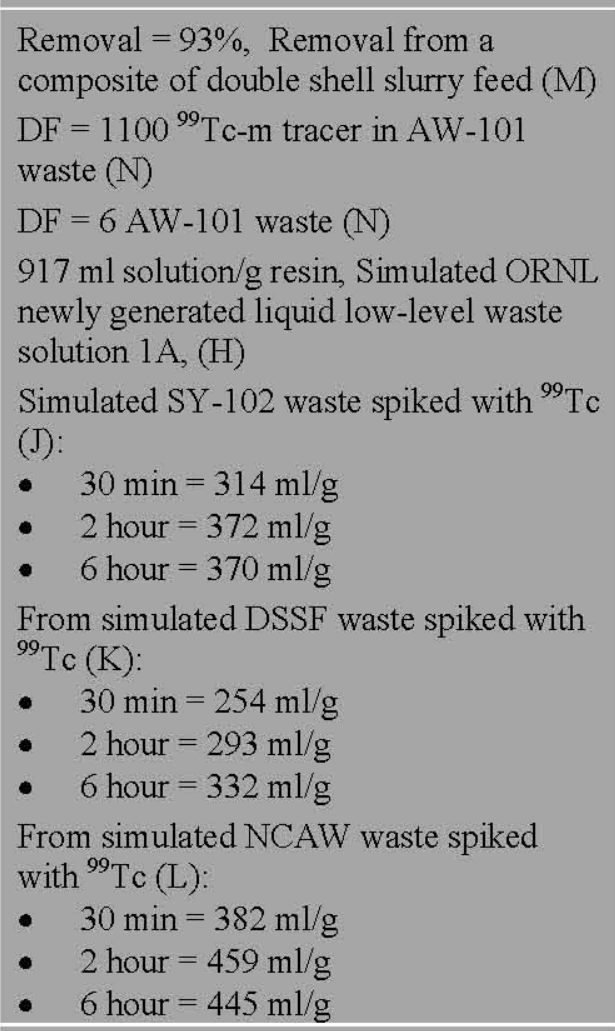 & $\begin{array}{l}\text { 99-99,9\% removal of }{ }^{99} \mathrm{TcV} \text { VII for Hanford } \\
\text { SST and DST waste envelope A, B, and } \\
\text { C (note that } \mathrm{t}^{99} \mathrm{Tc} \text { in envelope A waste is } \\
\sim 97 \% \%^{99} \mathrm{TcIIV} \text { and } \sim 30 \% \text { in envelope C } \\
\text { waste) (B) } \\
\text { DF factor is } \sim 400 \text { for }{ }^{99} \mathrm{TcVII} \\
\text { F factor }=0.9931 \text { (X) } \\
\text { Note: Many more } \mathrm{K}_{\mathrm{d}} \text { values are listed for } \\
\text { SuperLig } 639 \text { in section 3.2.7. }\end{array}$ \\
\hline Organic & Yes $(G)$ & Yes: Styrene-DB, Gel (F) & Yes $(\mathrm{T})$ & Yes (T) & No (I) & & Yes \\
\hline Particle Size & $\begin{array}{l}30-60 \text { mesh ( } \sim 250-600 \text { micron }) \\
(\mathrm{G})\end{array}$ & $\begin{array}{l}\text { 20-50 mesh } \\
(\sim 300-850 \text { micron })(Q)\end{array}$ & $\begin{array}{l}16-50 \text { mesh }(\sim 300- \\
1200 \text { micron) }(\mathrm{T})\end{array}$ & $\begin{array}{l}16-50 \text { mesh } \\
(\sim 300-1200 \text { micron } \\
\text { diameter })(\mathrm{T})\end{array}$ & $\begin{array}{l}\text { 20-50 mesh. } \\
(\sim 300-850 \text { micron })(\mathrm{I})\end{array}$ & $81 \%$ of beads were $260-450 \mu \mathrm{m}(\mathrm{N})$ & $\begin{array}{l}25-35 \text { mesh } \\
(\sim 500-700 \text { micron }) \\
26 \% 600 \text { to } 1000 \mu \mathrm{m} ; 60 \% 425 \text { to } 600 \\
\mu \mathrm{m}, 11 \% 300 \text { to } 425 \mu \mathrm{m}(\mathrm{X})\end{array}$ \\
\hline $\mathrm{pH}$ operating range & 6 to $14+(G)$ & 0 to $14(\mathrm{Q})$ & 0 to $14(\mathrm{~T})$ & Stable: 0 to $14(\mathrm{C})$ & 6.5 tol 4 (not for acidic & The vendor reports that there is a week & No limit in acidic, neutral or basic range. \\
\hline
\end{tabular}


RPP-RPT-50122

Table 3-6. Sorption Media Properties

\begin{tabular}{|c|c|c|c|c|c|c|c|}
\hline \multirow{2}{*}{$\begin{array}{l}\text { SORPTION } \\
\text { MEDIA } \\
\text { PROPERTY }\end{array}$} & \multirow[b]{2}{*}{ ABEC-2000® } & \multirow[b]{2}{*}{ DOWEX $®$ 1-X8 } & \multicolumn{2}{|c|}{ PUROLITE } & \multirow{2}{*}{$\begin{array}{l}\text { TAM - SnII Apatite } \\
\text { Microspheres } \\
\text { (Kurion, Inc.) }\end{array}$} & \multirow[b]{2}{*}{ REILLEX HPQ } & \multirow[b]{2}{*}{ SUPERLIG 639} \\
\hline & & & A520E & A530E & & & \\
\hline & $\begin{array}{l}\text { Good chemical resistance to } \\
\text { alkaline solutions (A) }\end{array}$ & $\begin{array}{l}\text { Good chemical resistance } \\
\text { to alkaline solutions (A) }\end{array}$ & & Operating: 4.5 to $8.5(\mathrm{C})$ & conditions) (I) & $\begin{array}{l}\text { hydrogen bond that would be lost in basic } \\
\text { solutions. They recommend } \mathrm{pH}<7 \text {. } \\
\text { They do not know of negative effects } \\
\text { from the weak bond reacting in high } \mathrm{pH} \\
\text { solutions. (U) } \\
\text { Good chemical resistance to alkaline } \\
\text { solutions (A) }\end{array}$ & $\begin{array}{l}\text { Optimal removal in high pH, high salt } \\
\text { concentration solutions (V) }\end{array}$ \\
\hline Poisons & $\begin{array}{l}\text { Reducing agents capable of } \\
\text { reducing }{ }^{99} \mathrm{Tc}(\mathrm{VII}) \text { will reduce } \\
\text { the }{ }^{99} \mathrm{Tc}(\mathrm{IV}) \text { which will not be } \\
\text { retained by the resin }(\mathrm{G})\end{array}$ & & $\begin{array}{l}\text { Competing anions are } \\
\mathrm{SO}_{4}, \mathrm{Cl}, \mathrm{HCO}_{3}, \mathrm{NO}_{3} \text {, } \\
\text { and } \mathrm{U}(\mathrm{T})\end{array}$ & $\begin{array}{l}\text { Competing anions } \mathrm{SO}_{4}, \\
\mathrm{Cl}, \mathrm{HCO}_{3}, \mathrm{NO}_{3} \text {, and } \mathrm{U} \\
\text { (T) }\end{array}$ & $\begin{array}{l}\text { Neither salts nor chelants seem } \\
\text { to have an affect (I) }\end{array}$ & & $\begin{array}{l}\text { None known or found in testing with } \\
\text { Hanford tank waste. Feed must be } \\
\text { clarified prior to delivery IX column, } \\
\text { otherwise as solids block access of } \mathrm{TcO}_{4}{ }^{-} \\
\text {to resin ligand sites }(\mathrm{V})\end{array}$ \\
\hline $\begin{array}{l}\text { Resin Density } \\
\text { (weight per unit } \\
\text { volume) }\end{array}$ & $\begin{array}{l}0.8 \mathrm{~g} / \mathrm{mL} \text { in } \mathrm{H}_{2} \mathrm{O} \text { and } 1.1 \mathrm{~g} / \mathrm{mL} \text { in } \\
6 \mathrm{M} \mathrm{KOH}(\mathrm{G})\end{array}$ & $\begin{array}{l}0.705 \mathrm{~g} / \mathrm{ml}\left(44 \mathrm{lbm} / \mathrm{ft}^{\wedge} 3\right) \text { at } \\
\sim 39-45 \% \text { water } \\
\rho=0.41 \mathrm{~g} / \mathrm{ml} \text { dry density } \\
\text { (F) } \\
\text { Packed bed yield volume } \\
7.5 \mathrm{ml} \text {, dry resin used } \\
2.84 \mathrm{~g} \\
\rho_{\mathrm{b}}=0.38 \mathrm{~g} \text { resin } / \mathrm{ml} \text { resin } \\
\text { in solution }(\mathrm{H}) \\
\text { Floats in } 5.6 \mathrm{M} \mathrm{NaOH} \\
(1.27 \mathrm{~g} / \mathrm{L})(\mathrm{A})\end{array}$ & $\begin{array}{l}0.675-0.705 \mathrm{~g} / \mathrm{ml} \\
\rho_{b}=0.351 \mathrm{~g} / \mathrm{ml}(J)\end{array}$ & $\begin{array}{l}0.670 \mathrm{~g} / \mathrm{ml} \\
(0.335 \mathrm{~g} / \mathrm{ml} \mathrm{dry})\end{array}$ & $\sim 1.37 \mathrm{~g} / \mathrm{ml}$ (dry) (I) & $\begin{array}{l}0.88 \mathrm{~g} / \mathrm{ml} \text { at } \sim 50 \% \text { water } \\
\left(25.2 \mathrm{Kg} / \mathrm{ft}^{\wedge} 3\right) \\
\rho=0.585 \mathrm{~g} / \mathrm{ml} \text { dry }(\mathrm{N}) \\
\rho=0.538 \mathrm{~g} / \mathrm{ml} \text { wet }(\mathrm{N}) \\
\rho_{\mathrm{b}}=0.352 \mathrm{~g} / \mathrm{ml}(\mathrm{J}) \\
\text { Likely floats in Feed Solution (A) }\end{array}$ & $\begin{array}{l}1.147 \mathrm{~g} / \mathrm{ml} \text { wet }(\mathrm{B}) \\
0.478 \mathrm{~g} / \mathrm{ml} \text { bulk dry }(\mathrm{B}) \\
1.07 \mathrm{grams} \text { of dry solids divided by the } \\
\text { volume of wet resin particles }(\mathrm{X})\end{array}$ \\
\hline Selectivity to ${ }^{99} \mathrm{Tc}$ & $\begin{array}{l}\text { The resin has good selectivity for } \\
{ }^{99} \mathrm{Tc}(\mathrm{VIII}) \text { but will co-extract I- } \\
\text { and } \operatorname{Re}(\mathrm{VIII})(\mathrm{G})\end{array}$ & & & & $\begin{array}{l}\text { Extremely specific at high salt } \\
\text { molarity and high pH (I) }\end{array}$ & & $\begin{array}{l}\text { Virtually infinite selectivity over } \mathrm{OH} ; \mathrm{Cl}^{-} \\
\mathrm{F}^{*}, \& \mathrm{Br}: \mathrm{NO}_{3} \text { is the primary } \\
\text { competitor }(\mathrm{V})\end{array}$ \\
\hline $\begin{array}{l}\text { Temperature } \\
\text { operating range }\end{array}$ & $10^{\circ} \mathrm{C}-50^{\circ} \mathrm{C}(\mathrm{G})$ & $66^{\circ} \mathrm{C}$ Maximum (Q) & $5-60^{\circ} \mathrm{C}(\mathrm{T})$ & $5-60^{\circ} \mathrm{C}(\mathrm{T})$ & $\begin{array}{l}\text { Made from glass microspheres } \\
\text { at high temperatures. So none } \\
\text { known. (I) }\end{array}$ & & $\begin{array}{l}5-40^{\circ} \mathrm{C} \\
\text { LAW feed not to exceed } 77^{\circ} \mathrm{F}\left(25^{\circ} \mathrm{C}\right)(\mathrm{B})\end{array}$ \\
\hline$\lambda_{50}$ & $\begin{array}{l}\lambda_{50} \text { breakthrough as } 40-60 \mathrm{BV} \text { at } \\
10 \mathrm{BV} / \mathrm{hr} \text { for Hanford waste }\end{array}$ & $\begin{array}{l}703 \mathrm{ml} \text { solution/ml resin } \\
\text { in column }(\mathrm{H})\end{array}$ & $\begin{array}{l}\lambda_{50}=130 \mathrm{ml} \\
\text { solution } / \mathrm{ml} \text { sorbent } \\
\text { media for SY-102 } \\
\text { simulant, } 30 \mathrm{~min} \text { contact } \\
\text { time }(\mathrm{J}) \\
\lambda_{50}=205 \mathrm{ml} \\
\text { solution } / \mathrm{ml} \text { sorbent } \\
\text { media for SY-102 } \\
\text { simulant, } 2 \mathrm{hr} \text { contact } \\
\text { time (J) }\end{array}$ & $\begin{array}{l}1.6 \mathrm{E} 04 \mathrm{ml} \text { solution } / \mathrm{ml} \\
\text { resin (for ETF waste } \\
\text { matrix; dilute compared } \\
\text { to expected LAW feed) } \\
\text { (O) }\end{array}$ & $\begin{array}{l}\text { 9.5E02 } \mathrm{ml} \mathrm{solution} / \mathrm{ml} \mathrm{dry} \\
\text { resin for AN-104 surrogate }\end{array}$ & $\begin{array}{l}\lambda_{50}=111 \mathrm{BV}{ }^{99} \mathrm{Tc}-\mathrm{m} \text { tracer in AW-101 } \\
\text { waste }(\mathrm{J}) \\
\lambda_{50}=131 \mathrm{BV} \text { AW-101 waste }(\mathrm{N}) \\
\lambda_{50}=88 \mathrm{ml} \text { solution } / \mathrm{ml} \text { sorbent media } \\
\text { for SY-102 simulant, 30min contact time } \\
\text { (J) }\end{array}$ & $\begin{array}{l}\text { Tank } 44 \mathrm{~F} \text { sample (reported as similar to } \\
\text { Hanford envelop A) resulted in } \\
\text { approximately } 89.4 \% \text { Tc removal } \\
\mathrm{K}_{\mathrm{d}}=950.1 \mathrm{~mL} / \mathrm{g} \text { ) } \\
\lambda_{50} \sim 500 \mathrm{BV} \text { in } \mathrm{AP}-101 \text { (W) } \\
\lambda_{50} \sim 360 \mathrm{BV} \text { in } \mathrm{AZ}-101 \text { (Y) } \\
\lambda_{50}=213 \mathrm{BV} \text { in AW-101 (D) }\end{array}$ \\
\hline
\end{tabular}


Table 3-6. Sorption Media Properties

REFERENCES (questionnaires are located in Appendix B)

A. 24590-PTF-RPT-RT-02-001, Rev 0, WTP PTF Alternative Resin Selection, Bechtel National, Inc, Richland, WA

B. 24590-WTP-RPT-PT-02-005, Rev 1, Flowsheet Bases, Assumptions, and Requirements, Bechtel National, Inc., Richland, Washington, 2002

C. Baker Corp TM product brochure (http://www.bakercorp.com/pdfs/A-530E.pdf).

D. BNFL-RPT-016 Rev 0., Small Column Testing of SuperLig ${ }^{\circledR} 639$ for Removing ${ }^{99}$ Tc From Hanford Tank Waste Envelope A (Tank 241-AW-101), Battelle, Pacific Northwest Division, Richland, Washington, 2000.

E. DE-AC21-97MC33137--43, Separation, Concentration, and Immobilization of Technetium and Iodine from Alkaline Supernate Waste, Eichrom Industries, Inc, Darien, Illinois, 1998.

F. DOW $\otimes$ Vendor Information (http://www.dowwaterandprocess.com/products/ix/dx_lx8.htm)

G. Eichrom Technologies LLC questionnaire.

H. K/TCD-1 141, Simulated ORNL newly generated liquid low-level waste solution 1A, pH 13

I. Kurion, Inc. questionnaire (Kurion homepage: http://www.kurion.com)

J. LA-12654 Rev., Distributions of 14 Elements on 63 Selected Absorbers from Three Simulant Solutions (Acid-Dissolved Sludge, Acidified Suprnate, and Alkaline Supernate) for Hanford HLW Tank 102-SY, Los Alamos National Laboratory, Los Alamos, New Mexico, 1994

K. LA-12863, Distributions of 15 Elements on 58 Absorbers from Simulated Hanford Double-shell Slurry Feed (DSSF), Los Alamos National Laboratory, Los Alamos, New Mexico, 1994

L. LA-12889, Distributions of 12 Elements on 64 Absorbers from Simulated Hanford Neutralized Current Acid Waste (NCWA), Los Alamos National Laboratory, Los Alamos, New Mexico, 1994.

M. PNNL-11386, Technetium in Alkaline, High-Salt, Radioactive Tank Waste Supernate: Preliminary Characterization andRemoval, D. L. Blanchard, Jr, et. Al., Pacific Northwest National Laboratory, Richland, Washington, January 1997.

N. PNNL-11398, Technetium Removal Column Flow Testing with Alkaline, High Salt, Radioactive Tank Waste, D. L. Blanchard, Jr, et. Al., Pacific Northwest National Laboratory, Richland, Washington, November 1997.

O. RPP-RPT-23199, Rev 0, The Rem

O. RPP-RPT-23199, Rey Laboratory, Argon, Illinois, 1996.

Q. Sigma-Aldrich (Fluka) (http://www.sigmaaldrich.com/catalog/ProductDetail.do?lang=en\&N4=44324/FLUKA\&N5=SEARCH_CONCAT PNO|BRAND KEY\&F=SPEC)

R. SRTC-BNFL-013 Rev 0, Evaluation of the Radiation Stability of SuperLig® 639, Westinghouse Savannah River Company, Aiken, South Carolina, 1997.

S. TAM Sn(II) Apatite Microspheres

T. The Purolite Company questionnaire (Purolite $\otimes$ homepage: http://www.purolite.com)

U. Vertellus $®$ questionnaire (Vertellus $\otimes$ homepage: http://www.vertellus.com)

V. IBC® Advanced Technologies questionnaire.

W. WTP-RPT-030, Rev 0, Small Column Testing of SuperLig® 639 for Removing ${ }^{99}$ Tc from Hanford Tank Waste Envelope A (Tank 241-AP-101), Battelle, Pacific Northwest Division, Richland, Washington, 2002.

X. WTP-RPT-031, Rev 1, Small Column Testing of SuperLig 639 for Removing ${ }^{99}$ Tc from Hanford Tank Waste 241-AN-102 Supernate (Envelope C) Mixed with Tank 241 -C-104 Solids (Envelope D) Wash and Permeate Solutions, Battelle, Pacific Northwest Division, Richland, Washington, 2004

Y. WTP-RPT-058, Rev 1, Small Column Testing of SuperLig $₫ 639$ for Removing ${ }^{99}$ Tc from Hanford Tank Waste Envelope B (Tank 241-AZ-101), Battelle - Pacific Northwest Division, Richland, Washington, 2004 


\subsubsection{ABECTM 2000 (Eichrom)}

Aqueous Biphasic Extraction Chromatography $(\mathrm{ABEC})^{\mathrm{TM}^{4}}$ resins have been demonstrated to selectively extract pertechnetate anions from alkaline radioactive waste. ABEC resins consist of monomethylated polyethylene glycol (PEG) bonded onto cross-linked chloromethylated polystyrene-1\%-divinyl-benzene backbone. The 2000 designation refers to the molecular weight of the PEG attached to the polystyrene support.

The resin behaves like an aqueous biphasic system (ABS), retaining chaotropic ions (such as $\mathrm{TcO}^{-}$, which interfere with stabilizing intramolecular interactions mediated by non-covalent forces such as hydrogen bonds, van der Waals forces, and hydrophobic effects) in the presence of high ionic strength solutions of water-structuring anions (such as $\mathrm{SO}_{4}{ }^{2-}, \mathrm{CO}_{3}{ }^{2-}, \mathrm{OH}^{-}$). Resin uptake of $\mathrm{TcO}^{-}$increases as the concentration of water structuring salt increases. The highest $\mathrm{K}_{\mathrm{d}}$ value for ABEC-2000 with Hanford waste was $410 \mathrm{ml} / \mathrm{g}$, obtained for testing with Tank SY101 waste. After loading, the resins are regenerated by elution with water.

Figure 3-1. ABEC 2000 Resin

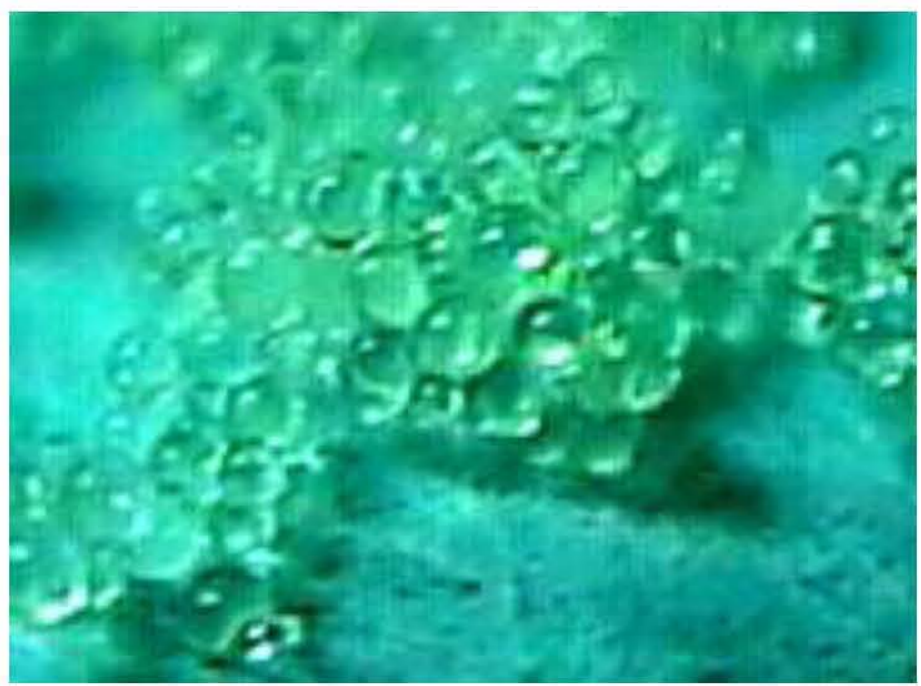

\subsubsection{Overview of Literature Reports for ABEC 2000}

a) Industrial \& Engineering Chemistry Research, 38, 1683-1689, Flowsheet Feasibility Studies Using ABEC Resins for Removal of Pertechnetate from Nuclear Wastes, Eichrom Industries, Inc., Darien, Illinois, University of Alabama, Tuscaloosa, Alabama, and Oak Ridge National Laboratory, Oak Ridge, Tennessee, 1999.

This report presents information regarding ABEC G2 sorption media. It is not known whether this media is a forerunner to ABEC 2000. The article contains a basic flowsheet for another ${ }^{99} \mathrm{Tc}$ disposal system path -- removal of ${ }^{99} \mathrm{Tc}$ from LAW using ABEC G2, elution with water, then capture and disposal on a Purolite ${ }^{\mathrm{TM}^{5}}$ sorption media.

\footnotetext{
${ }^{4}$ ABEC resins are trademarked products of Eichrom Technologies, Inc., of Lisle, Illinois.

${ }^{5}$ Purolite resins are trademarked products of The Purolite Company of Bala Cynwyd, Pennsylvania.
} 
b) RR196, New Technologies for Metal Ion Separations: Aqueous Biphasic Extraction Chromatography (ABEC). Part I. Uptake of Pertechnetate, Department of Chemistry, Northern Illinois University, DeKalb, Illinois, Argonne National Laboratory, Argonne, Illinois, 1996.

This report is an overview of synthesis and uptake properties of several ABEC Resins (350, 750,2000 , and 5000) and a summary of experiments performed to show that 1) resin uptake of $\mathrm{TcO}^{-}$increases as the concentration of the water-structuring salt increases, 2) resin uptake increases as $\Delta \mathrm{G}_{\mathrm{hyd}}$ of the water-structuring anions becomes more negative, 3) resin uptake increases as the molecular weight of the polymer increases, and 4) no uptake occurs from salt solutions that do not contain a sufficient concentration of bi-phase forming salt. Data for three different waste simulants (Tank SY-101, neutralized current acid waste, and SST waste) is presented as well as other studies of various salt solutions and $\mathrm{pH}$ solutions.

c) DE-AC21-97MC33137--43, Separation, Concentration, and Immobilization of Technetium and Iodine from Alkaline Supernate Waste, Eichrom Industries, Inc, Darien, Illinois, 1998.

This report describes work to synthesize an improved version of the ${ }^{99} \mathrm{Tc}$ selective resin to resolve performance issues of the original ABEC-5000 resin, including research to investigate the influence of certain copolymer substrate properties on the physical properties and uptake performance of ABEC resins. Properties included degree of cross-linking, copolymer bead porosity and number of potential sites for attachment of PEG. The report also includes a flowsheet for stabilization and disposal of ${ }^{99} \mathrm{Tc}$ by loading the ${ }^{99} \mathrm{Tc}$ which has been stripped from the ABEC resin with water onto a commercial silica-based anion exchange resin, NUCLEOSIL ${ }^{\mathrm{TM}^{6}}$ and then encapsulating it within a hydrous titanium oxide matrix. Waste streams include actual Hanford tank waste from Tank AW-101, (a Csdecontaminated, double-shell slurry feed (DSSF) composite), three different Hanford tank waste simulants, actual waste samples from Melton Valley Storage Tanks (MVSTs) W-29 and W-3 at the DOE's Oak Ridge National Laboratory (ORNL), and waste simulant solutions from two British Nuclear Fuels, Ltd. (BNFL) locations-Capenhurst and Sellafield - in the United Kingdom.

\subsubsection{Dowex ${ }^{\mathrm{TM}}$ 1-X8 (Dow Chemical)}

Dowex ${ }^{\mathrm{TM}^{7}} 1-\mathrm{X} 8$ is a Type 1 strongly basic anion exchange resin. Structurally it is a quaternary amine based resin on a cross-linked ( $8 \%$ ) styrene divinyl-benzene backbone. The resin is spherical and floats in 5.6 molar $(\mathrm{M}) \mathrm{NaOH}(1.27 \mathrm{~g} / \mathrm{L})$. It has good chemical resistance to alkaline solutions. Its typical eluent is $4 \mathrm{M}$ nitric acid $\left(\mathrm{HNO}_{3}\right)$

\footnotetext{
${ }^{6}$ Nucleosil resins are trademarked products of W.R. Grace and Company of Columbia, Maryland.

${ }^{7}$ Dowex is a trademarked product of the Dow Chemical Company of Midland, Michigan.
} 
RPP-RPT-50122

Figure 3-2. Dowex ${ }^{\mathrm{TM}}$ 1-X8 Resin

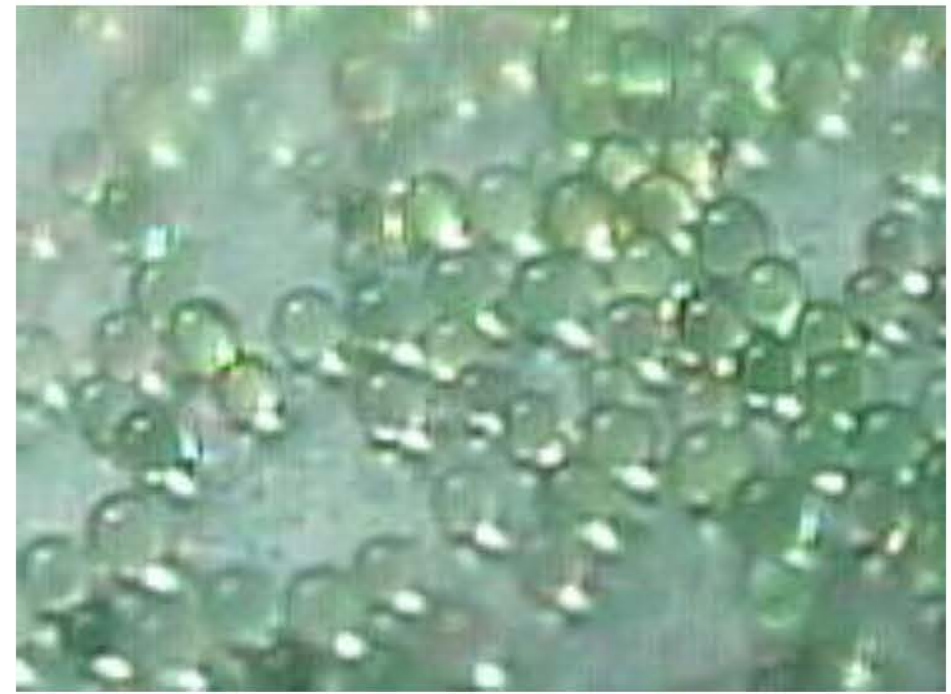

\subsubsection{Overview of Literature Reports for Dowex ${ }^{\mathrm{TM}}$ 1-X8}

Dowex 1-X8 has been reviewed by the WTP for Tc removal from LAW feedafter Cs removal. However, that report (24590-PTF-RPT-RT-02-001, Rev 0, WTP PTF Alternative Resin Selection) is business sensitive and has not been made available for WRPS review.

a) K/TCD-1141, Removal of Technetium-99 from Simulated Oak Ridge National Laboratory Newly-Generated Liquid Low-Level Waste, ORNL Chemical Technology Division, W. D. Bostick, et. Al, (Oak Ridge National Laboratory, Oak Ridge, Tennessee, 1995).

This reference is not directly applicable to immobilization of Hanford's LAW. The nitrate $\left(\mathrm{NO}_{3}{ }^{-}\right)$and salt concentrations for the simulant used are too low.

Oak Ridge National Laboratory also reviewed Dowex 1-X8 for ${ }^{99} \mathrm{Tc}$ removal from its Newly-Generated Liquid Low-Level Waste. The resin was tested on two waste simulants. The simulant with the highest $\mathrm{pH}$ and salt concentrations is listed in Figure 3-3. Although the simulant has high $\mathrm{pH}$, the concentrations of the salts are too low for accurate comparison with Hanford wastes. Regarding use of this resin on Hanford waste, the report comments:

"It should be noted that loading of ${ }^{99} T \mathrm{Tc}$ on Type 1 strongly basic anion exchange resin (such as Dowex ${ }^{\mathrm{TM}} 1-X 8$ ) is adversely affected by high concentrations of competing nitrate ion; this situation could occur if NGLLLW is blended with a relatively large proportion of high-nitrate legacy waste from the Melton Valley Storage Tanks"

Another comment of interest is the finding regarding completely loading the sorption media with ${ }^{99} \mathrm{Tc}$. Based on the ORNL simulant and testing, Dowex 1-X8 laden with ${ }^{99} \mathrm{Tc}$ would hold $170 \mathrm{Ci}^{99} \mathrm{Tc} / \mathrm{m}^{3}$. 
Figure 3-3. Newly-Generated Liquid Low-Level Waste Simulate Composition (K/TCD1141)

Table 1. Composition of Simulated NGLLLW ${ }^{\mathrm{s}}$

\begin{tabular}{|c|c|}
\hline Component or Property & Value \\
\hline $\mathrm{NaOH}$ & $0.125 \mathrm{~mol} / \mathrm{L}(5.0 \mathrm{~g} / \mathrm{L})$ \\
\hline $\mathrm{Na}_{2} \mathrm{CO}_{3}$ & $0.10 \mathrm{~mol} / \mathrm{L}(10.6 \mathrm{~g} / \mathrm{L})$ \\
\hline $\mathrm{NaNO}_{3}$ & $0.06 \mathrm{~mol} / \mathrm{L}(5.1 \mathrm{~g} / \mathrm{L})$ \\
\hline $\mathrm{NaCl}$ & $0.034 \mathrm{~mol} / \mathrm{L}(2.0 \mathrm{~g} / \mathrm{L})$ \\
\hline $\mathrm{LiCl}$ & $0.025 \mathrm{~mol} / \mathrm{L}(1.06 \mathrm{~g} / \mathrm{L})$ \\
\hline $\mathrm{NaAlO}_{2}$ & $0.012 \mathrm{~mol} / \mathrm{L}(0.98 \mathrm{~g} / \mathrm{L})$ \\
\hline Solution $\mathrm{pH}$ & $\sim 13$ standard units \\
\hline Solution density & $\sim 1.07 \mathrm{~g} / \mathrm{L}$ \\
\hline
\end{tabular}

\subsubsection{Purolite ${ }^{\mathrm{TM}}$ A520E}

\section{Figure 3-4. Purolite ${ }^{\mathrm{TM}}$ A520E}

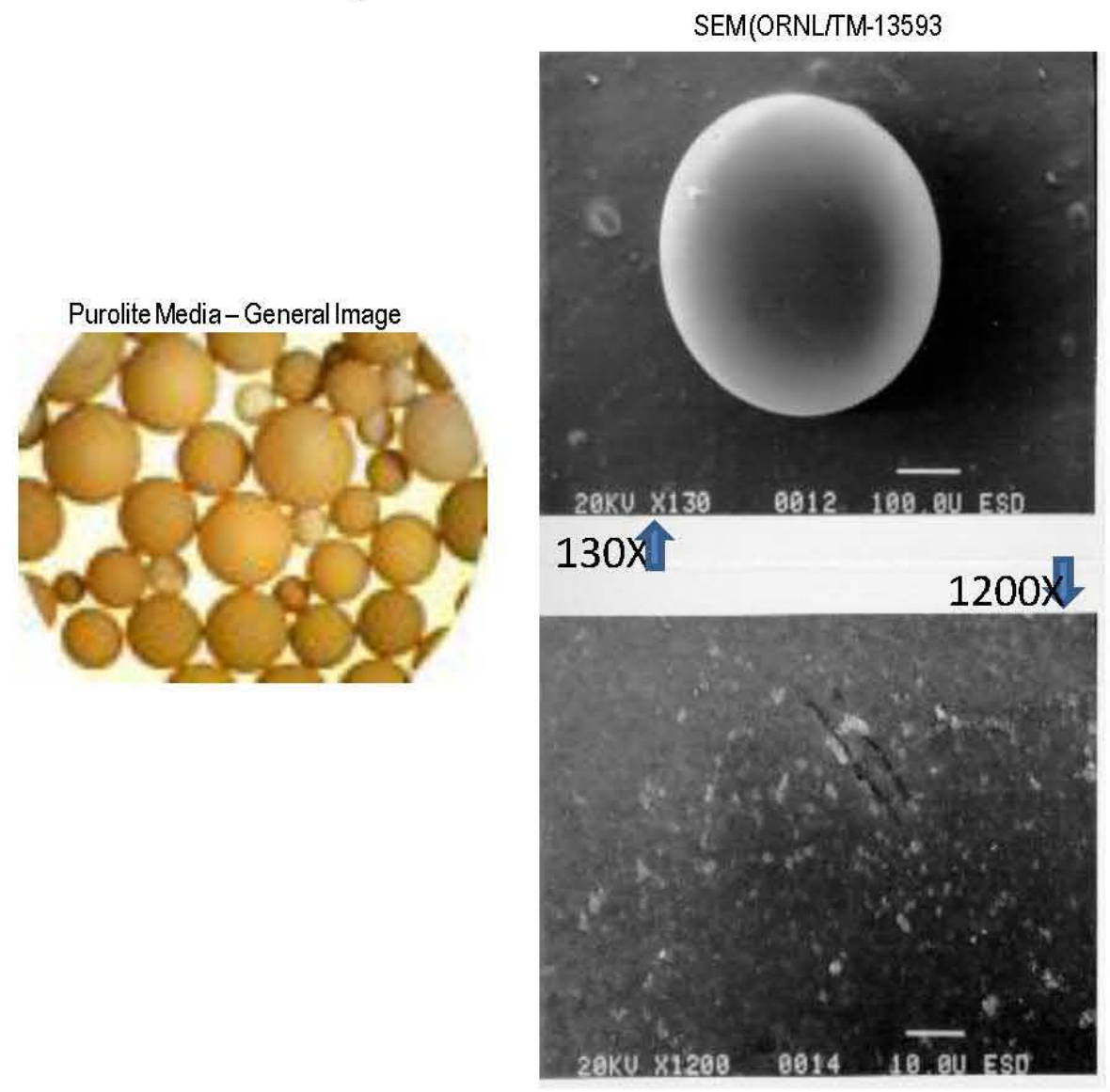


Purolite A520E is a strong base anion resin designed for the removal of nitrates from water for potable processes. It is a macroporous polystyrene crosslinked with divinylbenzene, and the functional group is a Type 1 quaternary ammonium pendant group. Macroporous resins are highly cross-linked polymers penetrated by open spaces through which solutions are able to flow. It has an exchange capacity of $0.9 \mathrm{eq} / \mathrm{L}$ in the chloride form, specific gravity of 1.07 , and particle size range of 300 to 1200 microns. (Purolite Literature http://www.purolite.com/default.aspx?RelID=606288\&ProductID=223)

\subsubsection{Overview of Literature Reports for Purolite ${ }^{\mathrm{TM}}$ A520E}

a) LA-12654 Rev., Distributions of 14 Elements on 63 Selected Absorbers from Three Simulant Solutions (Acid-Dissolved Sludge, Acidified Supernate, and Alkaline Supernate) for Hanford HLW Tank 102-SY, Los Alamos National Laboratory, Los Alamos, New Mexico, 1994.

The alkaline simulant used for this work is slightly low in ionic strength to be directly applicable to the processing of LAW waste and removal of ${ }^{99} \mathrm{Tc}$. The simulant was based from on Tank SY-102, so it is applicable to some portion of Hanford's LAW feed. Three simulants where tested with only the alkaline solution of interest, its matrix is shown in Figure 3-5. The results of the study with respect to ${ }^{99} \mathrm{Tc}$ and Purolite $520 \mathrm{E}$ are best presented by review of Figure 3-6 and Figure 3-7. Elution of sorption media was not investigated. 
Figure 3-5. Tank SY-102 Alkaline Supernate Simulant (Table 2, LA-12654, Rev.)

Table 2. Compositions of Hanford Tank 102-SY Simulant Solutions

\begin{tabular}{|c|c|c|}
\hline & $\begin{array}{l}\text { (Acid-DissolvedSludge and Acidified Supernate } \\
\text { compositions removed to minimize confusion) }\end{array}$ & $\begin{array}{c}\text { Alkaline } \\
\text { Supernate }\end{array}$ \\
\hline $\begin{array}{l}\text { Cations } \\
\mathrm{Na} \\
\mathrm{Mg} \\
\mathrm{Al} \\
\mathrm{Si} \\
\mathrm{Ca} \\
\mathrm{Cr}(\mathrm{III}) \\
\mathrm{Cr}(\mathrm{VI}) \\
\mathrm{Mn} \\
\mathrm{Fe} \\
\mathrm{Ni} \\
\mathrm{Cu} \\
\mathrm{Se} \\
\mathrm{Sr} \\
\mathrm{Pb} \\
\mathrm{Th} \\
\mathrm{U} \\
{ }^{239} \mathrm{Pu} \\
{ }^{238} \mathrm{Pu}\end{array}$ & & $\begin{array}{l}2.2 \mathrm{M} \\
\text { none } \\
0.16 \mathrm{M} \\
0.0024 \mathrm{M} \\
0.0069 \mathrm{M} \\
\text { none } \\
0.0051 \mathrm{M} \\
\text { none } \\
0.0061 \mathrm{M} \\
\text { BDL } \\
\text { BDL } \\
\text { BDL } \\
\text { BDL } \\
\text { BDL } \\
\text { BDL } \\
\text { BDL } \\
\text { BDL } \\
\text { none }\end{array}$ \\
\hline $\begin{array}{l}\text { Anions }^{5} \\
\mathrm{~F} \\
\mathrm{Cl} \\
\mathrm{NO}_{3} \\
\mathrm{PO}_{4} \\
\mathrm{SO}_{4} \\
\end{array}$ & & $\begin{array}{l}0.21 \mathrm{M} \\
0.102 \mathrm{M} \\
1.31 \mathrm{M} \\
0.061 \mathrm{M} \\
0.022 \mathrm{M} \\
\end{array}$ \\
\hline $\begin{array}{l}\mathrm{pH} \\
\text { calculated } \mathrm{H}^{+} \\
\text {calculated } \mathrm{OH}^{-}\end{array}$ & & $\frac{13.85}{-}$ \\
\hline
\end{tabular}


RPP-RPT-50122

Figure 3-6. Results by Adsorber for Technetium (LA-12654 Rev.)

Table 8. Technetium Distribution Data (Cont.)

\begin{tabular}{|c|c|c|c|c|}
\hline \multirow{2}{*}{ Solution } & \multirow[b]{2}{*}{ Absorber } & \multicolumn{3}{|c|}{ Kd Value for Specified Time } \\
\hline & & $30 \mathrm{~min}$ & $2 \mathrm{~h}$ & $6 \mathrm{~h}$ \\
\hline Alkaline & Aliquat ${ }^{\mathrm{TM}} 336$ & 417 & 614 & 651 \\
\hline \multirow[t]{16}{*}{ Supernate } & Purolite ${ }^{\mathrm{TM}}$ A-520-E & 371 & 585 & 620 \\
\hline & Reillex TM HPQ & 314 & 372 & 370 \\
\hline & Sybron $^{\mathrm{TM}}(\mathrm{Et})_{3} \mathrm{~N}$ resin & 279 & 446 & 521 \\
\hline & Sybron $^{\mathrm{TM}}(\mathrm{Pr})_{3}^{3} \mathrm{~N}$ resin & 262 & 277 & 554 \\
\hline & Ionac $^{\mathrm{TM}} \mathrm{SR}-3^{3}$ & 222 & 272 & 258 \\
\hline & Ionac TM SR-6 & 191 & 385 & 520 \\
\hline & Sr-Spec'TM & 82 & 81 & 76 \\
\hline & Cyanex TM 923 & 80 & 116 & 110 \\
\hline & Crypt-DER & 31 & 38 & 38 \\
\hline & DHDECMP & 21 & 23 & 21 \\
\hline & $\mathrm{LIX}^{\mathrm{TM}}-26$ & 21 & 23 & 22 \\
\hline & DHDECMP-DIPB & 14 & 14 & 13 \\
\hline & TRU-SpecTM & 7.6 & 7.5 & 7.2 \\
\hline & CMPO-DIPB & 4.5 & 6.8 & 7.6 \\
\hline & Tannin & 4.3 & 5.4 & 4.0 \\
\hline & Bone char & 2.9 & 5.1 & 4.9 \\
\hline
\end{tabular}

Figure 3-7. Purolite ${ }^{\mathrm{TM}}$ A520E Distribution Coefficients by Analyte (LA-12654 Rev.)

Table 34. Purolite ${ }^{\mathrm{TM}}$ A-520-E Anion Exchange Resin: Distribution of 14 Elements from Three Simulant Solutions for Hanford Tank 102-SY

\begin{tabular}{lcrrr}
\hline & & \multicolumn{3}{c}{ Kd Value for Specified Time } \\
\cline { 3 - 5 } Solution & Element & $\mathbf{3 0} \mathbf{~ m i n}$ & $\mathbf{2 ~} \mathbf{~}$ & $\mathbf{6 ~ h}$ \\
\hline Alkaline & $\mathrm{Ce}$ & $<0.1$ & 0.2 & $<0.1$ \\
Supernate & $\mathrm{Cs}$ & 0.8 & 0.2 & 0.3 \\
& $\mathrm{Sr}$ & 0.5 & 1.2 & 1.5 \\
& $\mathrm{Tc}$ & 371 & 585 & 620 \\
& $\mathrm{Y}$ & 0.5 & 1.2 & 2.0 \\
& $\mathrm{Cr}$ & 0.8 & 0.3 & 0.6 \\
& $\mathrm{Co}$ & 1.0 & 0.3 & 0.4 \\
& $\mathrm{Fe}$ & 0.4 & 0.4 & 1.0 \\
& $\mathrm{Mn}$ & $<0.1$ & 0.2 & 1.1 \\
& $\mathrm{Zn}$ & 0.3 & $<0.1$ & $<0.1$ \\
& $\mathrm{Zr}$ & 0.8 & 0.3 & 0.6 \\
& $\mathrm{U}$ & 0.8 & 0.7 & 0.8 \\
& $\mathrm{Am}$ & $<0.1$ & $<0.1$ & $<0.1$ \\
\hline \hline
\end{tabular}


b) LA-12863, Distributions of 15 Elements on 58 Absorbers from Simulated Hanford Double-shell Slurry Feed (DSSF), Los Alamos National Laboratory, Los Alamos, New Mexico, 1994.

This report is directly applicable to ${ }^{99} \mathrm{Tc}$ removal from Hanford's LAW waste stream. The study builds off of previous work performed by LANL. The simulant used is based off double shell slurry feed (DSSF), Figure 3-8. Results for Purolite A520E are best represented by Figure 3-9 and Figure 3-10.

Figure 3-8. DSSF Simulant Composition (LA-12863)

Table 2. Composition of Simulated Hanford DSSF Solution Used in This Study

\begin{tabular}{ll} 
& Concentration $(\mathbf{M})$ \\
\hline Cations & \\
$\mathrm{Na}$ & 7.0 \\
$\mathrm{~K}$ & 0.945 \\
$\mathrm{Cs}$ & $7.0 \times 10^{-5}$ \\
$\mathrm{Al}$ & 0.721 \\
$\mathrm{Anions}$ & \\
$\mathrm{Cl}$ & 0.102 \\
$\mathrm{NO}_{3}$ & 3.52 \\
$\mathrm{NO}_{2}$ & 1.51 \\
$\mathrm{PO}_{4}$ & 0.014 \\
$\mathrm{SO}_{4}$ & 0.008 \\
$\mathrm{CO}_{3}$ & 0.147 \\
$\mathrm{OH}^{-}$(total) & 4.63 \\
$\mathrm{OH}^{-}$(free) & 1.75 \\
\hline Theoretical $\mathrm{pH}=14.56$ \\
Measured $\mathrm{pH}=14.0$ \\
\hline \hline
\end{tabular}


Figure 3-9. Results by Adsorber for Technetium (LA-12863)

Table 8. Technetium Distribution Data

\begin{tabular}{|c|c|c|}
\hline $30 \mathrm{~min}$ & $2 \mathrm{~h}$ & $6 \mathrm{~h}$ \\
\hline 254 & 293 & 332 \\
\hline 189 & 392 & 527 \\
\hline 177 & 464 & 524 \\
\hline 167 & 401 & 471 \\
\hline 121 & 244 & 230 \\
\hline 115 & 279 & 312 \\
\hline 96 & 257 & 390 \\
\hline 45 & 105 & 188 \\
\hline 15 & 24 & 26 \\
\hline
\end{tabular}

Figure 3-10. Purolite ${ }^{\mathrm{TM}}$ A520E Distribution coefficients by Analyte (LA-12863)

\begin{tabular}{|c|c|c|c|}
\hline \multirow[b]{2}{*}{ Element } & \multicolumn{3}{|c|}{ Kd Value for Specified Time } \\
\hline & $30 \mathrm{~min}$ & $2 \mathrm{~h}$ & $6 \mathrm{~h}$ \\
\hline$\overline{\mathrm{Ce}}$ & 5.4 & 6.0 & 19 \\
\hline Cs & 0.2 & $<0.1$ & $<0.1$ \\
\hline $\mathrm{Sr}$ & 0.4 & 0.4 & 0.4 \\
\hline $\mathrm{Tc}$ & 189 & 392 & 527 \\
\hline $\mathbf{Y}$ & 2.8 & 3.4 & 4.3 \\
\hline $\mathrm{Cr}$ & $<0.1$ & $<0.1$ & 0.1 \\
\hline Co & 0.3 & 0.4 & 0.7 \\
\hline $\mathrm{Fe}$ & 0.2 & 1.0 & 1.4 \\
\hline Mn & 0.5 & 1.0 & 1.5 \\
\hline $\mathrm{Ni}$ & 0.6 & 0.9 & 1.5 \\
\hline $\mathrm{V}$ & $<0.1$ & $<0.1$ & $<0.1$ \\
\hline $\mathrm{Zn}$ & $<0.1$ & 0.2 & 0.6 \\
\hline $\mathrm{Zr}$ & 0.6 & 1.4 & 1.5 \\
\hline$\vec{U}$ & $<0.1$ & 0.4 & 0.7 \\
\hline Am & 4.9 & 5.4 & 8.8 \\
\hline
\end{tabular}

c) LA-12889, Distributions of 12 Elements on 64 Absorbers from Simulated Hanford Neutralized Current Acid Waste (NCWA), Los Alamos National Laboratory, Los Alamos, New Mexico, 1994.

This report is directly applicable to ${ }^{99} \mathrm{Tc}$ removal from Hanford's LAW waste stream. The study builds off of previous work performed by LANL. The simulant used is based off neutralized current acid waste (NCAW), Figure 3-11. Results for Purolite A520E are best represented by Figure 3-12 and Figure 3-13. 
Figure 3-11. NCAW Simulant Composition (LA-12889)

\begin{tabular}{ll}
\hline Table 2. Composition of Simulated Hanford \\
NCAW Solution Used in This Study \\
\hline \multicolumn{2}{c}{ Concentration (M) } \\
\hline Cations \\
$\mathrm{Na}$ & 4.987 \\
$\mathrm{~K}$ & 0.120 \\
$\mathrm{Rb}$ & $5.0 \times 10^{-5}$ \\
$\mathrm{Cs}$ & $5.0 \times 10^{-4}$ \\
$\mathrm{Al}$ & 0.430 \\
Anions & \\
$\mathrm{F}$ & 0.089 \\
$\mathrm{NO}_{3}$ & 1.669 \\
$\mathrm{NO}_{2}$ & 0.43 \\
$\mathrm{PO}_{4}$ & 0.025 \\
$\mathrm{SO}_{4}$ & 0.15 \\
$\mathrm{CO}_{3}$ & 0.23 \\
$\mathrm{OH}^{-}$(total) & 3.4 \\
$\mathrm{OH}^{-}$(free) & 1.68 \\
\hline Theoretical & $\mathrm{pH}=14.52$ \\
$\mathrm{Measured}^{\mathrm{pH}=14.2}$ \\
\hline
\end{tabular}

Figure 3-12. Results by Adsorber for Technetium (LA-12889)

Table 7. Technetium Distribution Data

\begin{tabular}{|c|c|c|c|}
\hline \multirow[b]{2}{*}{ Absorber } & \multicolumn{3}{|c|}{ Kd Value for Specified Time } \\
\hline & $30 \mathrm{~min}$ & $2 \mathrm{~h}$ & $6 \mathrm{~h}$ \\
\hline TEVA-Spec TM & 1101 & 1259 & 1209 \\
\hline Aliquat $^{\text {TM }} 336$ & 455 & 679 & 775 \\
\hline Reillex ${ }^{\mathrm{TM}} \mathrm{HPQ}$ & 382 & 459 & 445 \\
\hline Purolite TM A-520-E & 329 & 660 & 782 \\
\hline Sybron (Et) ${ }_{3} \mathrm{~N}$ & 303 & 571 & 739 \\
\hline Ionac TM SR-3 & 227 & 385 & 407 \\
\hline Sybron $(\mathrm{Pr})_{3} \mathrm{~N}$ & 218 & 488 & 705 \\
\hline Cyanex TM 923 & 185 & 212 & 188 \\
\hline Ionac ${ }^{\text {TM }}$ SR-6 & 127 & 308 & 544 \\
\hline Nusorb ${ }^{\text {TM }}$ LP-70-S & 31 & 46 & 47 \\
\hline SRS RF BSC-187 & 5.0 & 33 & 232 \\
\hline Tannin & 4.7 & 15 & 62 \\
\hline
\end{tabular}

Figure 3-13. Purolite ${ }^{\text {TM }}$ A520E Distribution coefficients by Analyte (LA-12889)

\begin{tabular}{|c|c|c|c|}
\hline \multirow[b]{2}{*}{ Element } & \multicolumn{3}{|c|}{ Kd Value for Specified Time } \\
\hline & $30 \mathrm{~min}$ & $2 \mathrm{~h}$ & $6 \mathrm{~h}$ \\
\hline Cs & 0.1 & 0.2 & 0.1 \\
\hline $\mathrm{Sr}$ & $<0.1$ & $<0.1$ & $<0.1$ \\
\hline Tc & 329 & 660 & 782 \\
\hline $\mathrm{Y}$ & 1.4 & 1.5 & 1.6 \\
\hline $\mathrm{Cr}$ & 0.1 & 0.2 & 0.2 \\
\hline Co & 0.6 & 0.7 & 0.6 \\
\hline $\mathrm{Fe}$ & 0.7 & 1.2 & 1.2 \\
\hline Mn & 0.9 & 1.3 & 1.3 \\
\hline $\mathrm{Ni}$ & 0.6 & 0.7 & 0.4 \\
\hline V & 0.6 & 0.7 & 0.6 \\
\hline $\mathrm{Zn}$ & 0.5 & 0.6 & 0.5 \\
\hline $\mathrm{Zr}$ & 0.8 & 0.9 & 0.8 \\
\hline
\end{tabular}


d) ORNL/TM-13593, A Field Trial of Novel Bifunctional Resins for Removing Pertechetate (TcO4-) from Contaminated Groundwater, Oak Ridge National Laboratory, Lockheed Martin Energy Research Corporation, Oak Ridge, Tennessee, 1998.

Testing was performed on groundwater and is not directly applicable to Hanford's LAW feed. Of possible note is that $\mathrm{SO}^{-2}$ was retained in the sorption media.

\subsubsection{Purolite A530E $^{\mathrm{TM}}$}

Purolite A530E has been investigated by DOE contractors in several different programs for remediation of ${ }^{99} \mathrm{Tc}$. The sorption media is strong base anion, crosslinked with divinylbenzene. The formulation is selective for hydrophobic anions. The result is a sorption media that has high selectivity to perchlorate and pertechnetate ions. The bonding strength of media to pertechnetate makes elution difficult, and the vendor recommends a single pass system. The Purolite A530E is based on the biquat resin invented at ORNL by Gu, et al. ${ }^{8}$ Like the Purolite A520E, it is a macroporous resin with a polystyrene crosslinked with divinylbenzene. The functional group is a quaternary ammonium pendant group. The resin is for perchlorate and pertechnetate removal. It has a capacity of $0.6 \mathrm{eq} / \mathrm{L}$, a particle size of 300 to 1200 microns, and specific gravity of 1.7. (http://www.purolite.com/default.aspx?RelID=606288\&ProductID=333)

\subsubsection{Overview of Literature Reports for Purolite ${ }^{\mathrm{TM}} \mathrm{A530E}$}

a) PNNL-19681, Tc-99 Ion Exchange Resin Testing, Pacific Northwest Laboratory, Pacific Northwest National Laboratory, Richland, Washington, 2010.

Testing was performed for CH2M Hill Central Plateau Remediation Company for removal of

${ }^{99} \mathrm{Tc}$ from groundwater. Although the solution processed was not applicable to Hanford LAW, the results of the work performed may be applicable depending on the method of disposal chosen for ${ }^{99} \mathrm{Tc}$.

Goals for the work were to evaluate release of ${ }^{99} \mathrm{Tc}$ from the spent ion exchange resin after several years of storage, whether hot water stripping could be used to remove carbon tetrachloride from the spent resin without release of ${ }^{99} \mathrm{Tc}$, and whether the sorption media could be encapsulated into a cementitious waste form. If it could be incorporated, what would the release rate of the monolith be due to weathering? The leachability study showed less than $0.02 \%$ of the ${ }^{99} \mathrm{Tc}$ released. The Purolite A530E also held onto the ${ }^{99} \mathrm{Tc}$ through the hot water wash. Encapsulation of spent resin in a cementitious material was not conclusive, and further testing is required to determine physical degradation caused by moisture loss and the effect of this degradation process on the release of ${ }^{99} \mathrm{Tc}$.

b) RPP-RPT-23199, Rev 0, The Removal of Technetium-99 from the Effluent Treatment Facility Basin 44 Waste Using Purolite A-530E, Reillex HPQ, and Sybron IONAC SR-7 Ion Exchange Resins, CH2MHill Hanford Co. Richland, Washington, 2004.

\footnotetext{
${ }^{8}$ Gu, B.; G.M. Brown, P.V. Bonnesen, L. Liang, B. A. Moyer, R. Ober, and S. D. Alexandrotos, 2000, "Development of Novel Bifunctional Anion-Exchange Resins with Improved Selectivity for Pertechnetate Sorption from Contaminated Groundwater," Environmental Science and Technology, (Washington, DC) 34B, 1075-1080.
} 
The goal of work documented here was to evaluate and compare candidate anion exchange resins for their capacity to remove ${ }^{99} \mathrm{Tc}$ from Basin 44 Reverse Osmosis (RO) reject stream. Due to the makeup of the solution processed, this work is not applicable to Hanford's LAW.

c) RPP-RPT-39195, Rev 1, Assessment of Technetium Leachability in Cement-Stabilized Basin 43 Groundwater Brine, Washington River Protection Solutions, Richland, Washington, 2009.

The solution tested was $\sim 2.1 \mathrm{M}$ sodium (Na), formulated to match the anticipated Basin 43 waste from the Effluent Treatment Facility (ETF), and is not directly applicable to Hanford's LAW. The report does show Purolite A530E as having a good leach index for ${ }^{99} \mathrm{Tc}$.

\subsubsection{Reillex ${ }^{\mathrm{TM}}$ HPQ (Vertellus ${ }^{\circledR}$ )}

Reillex $\mathrm{TM}^{9}$ HPQ is a quaternary amine based resin on a cross-linked styrene divinyl-benzene backbone. The resin is in the form of spherical beads. The resin sinks in deionized water but will likely float in LAW feed. The resin is elutable with either $8 \mathrm{M} \mathrm{HNO}_{3}$ or a $1 \mathrm{M}$ sodium hydroxide $(\mathrm{NaOH}), 1 \mathrm{M}$ ethylene diamine, $0.005 \mathrm{M}$ tin ( $\mathrm{Sn})(\mathrm{II})$ solution. The harsh eluants required for stripping may allow this media to perform as a non-elutable.

Figure 3-14. Reillex ${ }^{\text {TM }}$ HPQ Resin

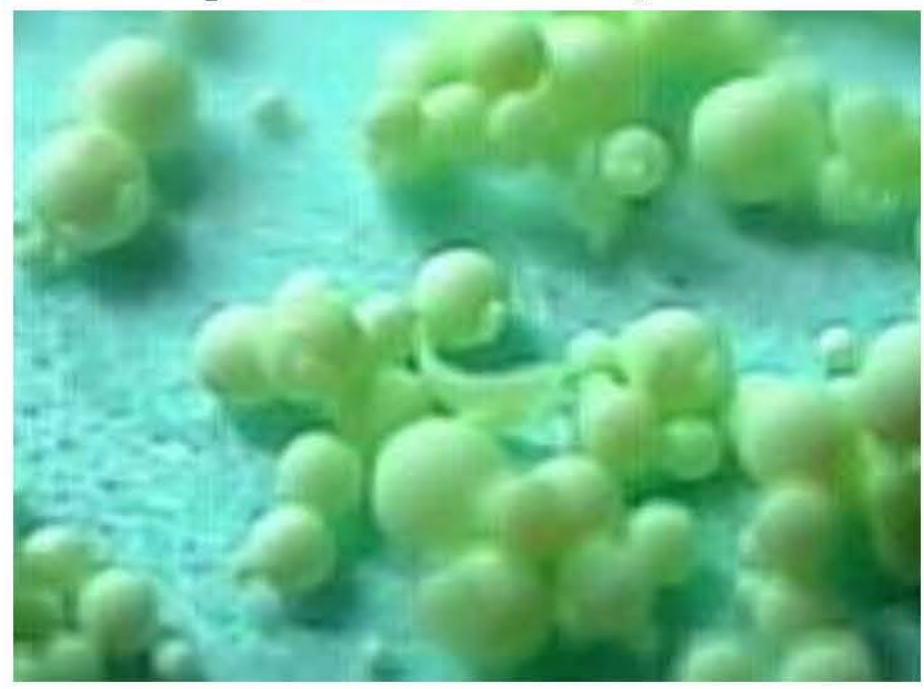

There is some concern with the vendor regarding degradation the sorption media at the $\mathrm{pH}$ range required for processing LAW feed. The concern has not been observed by the vendor or in testing performed on LAW feed.

\subsubsection{Overview of Literature Reports for Reillex ${ }^{\mathrm{TM}} \mathrm{HPQ}$}

a) CONF-9505101--1, Batch Test Equilibration Studies Examining the Removal of Cs, Sr, and Tc from Supernatants from ORNL Underground Tanks by Selected Ion Exchangers, Oak Ridge National Laboratory, Oak Ridge, Tennessee, 1995.

Based on information provided in the report on the solutions tests, this report is applicable to the capture of ${ }^{99} \mathrm{Tc}$ by sorbent media from Hanford's LAW. The solution used for this work was supernatant samples from MVSTs W-29, see Table 3-7.

\footnotetext{
${ }^{9}$ Reillex products are trademarked by Vertellus Specialties, Inc., of Indianapolis, Indiana.
} 
RPP-RPT-50122

Table 3-7. Solution Properties (CONF-9505101-1)

\begin{tabular}{|l|c|c|}
\hline \multicolumn{1}{|c|}{ Parameter } & Units & W-29 \\
\hline $\mathrm{NO} 3$ & gmol/L & 4.5 \\
\hline $\mathrm{Na}$ & $\mathrm{gmol} / \mathrm{L}$ & 4.4 \\
\hline${ }^{99} \mathrm{Tc}$ & $\mathrm{Ci}$ & $5.41 \mathrm{E}-07$ \\
\hline Density & $\mathrm{g} / \mathrm{ml}$ & 1.226 \\
\hline $\mathrm{pH}$ & $\mathrm{pH}$ & 13.2 \\
\hline
\end{tabular}

Note: $\quad$ Units for $\mathrm{NO}_{3}{ }^{-}, \mathrm{Na}$ and ${ }^{99} \mathrm{Tc}$ have been converted to match those in Table 3-1.

The ${ }^{99} \mathrm{Tc}$ concentration was adjusted to a concentration near the average of 17 Hanford underground storage tanks. The report looked at four sorbent media for ${ }^{99} \mathrm{Tc}$ removal, as shown in Figure 3-15.

Figure 3-15. ${ }^{99}$ Te Batch Adsorption Data for MVST W-29 Supernate (CONF-9505101-1)

\begin{tabular}{|c|c|c|c|c|}
\hline \multirow[b]{3}{*}{ Exchanger $^{b}$} & \multicolumn{4}{|c|}{ Mixing time (h) } \\
\hline & \multicolumn{2}{|c|}{ (2) } & \multicolumn{2}{|c|}{ (24) } \\
\hline & $\begin{array}{c}\mathrm{D} \\
(\mathrm{mL} / \mathrm{g})\end{array}$ & $\% \mathrm{R}$ & $\begin{array}{c}\text { D } \\
-\quad(\mathrm{mL} / \mathrm{g})\end{array}$ & $\% \mathrm{R}$ \\
\hline Reillex ${ }^{\mathrm{TM}} \mathrm{HPQ}^{\circ}$ & 282 & 60 & 624 & 76 \\
\hline Reillex ${ }^{\mathrm{TM}} \mathrm{HPQ}^{d}$ & 149 & 44 & 511 & 72 \\
\hline Reillex TM $402^{c}$ & 430 & 69 & 786 & 80 \\
\hline Reillex ${ }^{\mathrm{TM}} 402^{\mathrm{d}}$ & 349 & 64 & 356 & 66 \\
\hline Amberlite ${ }^{\mathrm{TM}}$ IRA-904 & 186 & 48 & 628 & 76 \\
\hline Amberlite ${ }^{\mathrm{TM}}$ IRA-904 & 286 & 59 & 535 & 74 \\
\hline Amberlite ${ }^{\mathrm{TM}}$ IRA-400 & 88 & 31 & 412 & 68 \\
\hline $\begin{array}{l}\text { "Descriptions of the W-29 supernat } \\
\text { PROCEDURES." } \\
\text { "Tthe ion exchangers are discusse } \\
\text { "Hydroxide form of exchanger. } \\
\text { "Nitrate form of exchanger. }\end{array}$ & entitled & $\begin{array}{l}\text { id the b: } \\
\text { ngers } T\end{array}$ & $\begin{array}{l}\text { edure are given } \\
\text { chnetium." }\end{array}$ & ction e \\
\hline
\end{tabular}

b) CONF-970148 - 3, Comprehensive Supernate Treatment, Oak Ridge National Laboratory, Oak Ridge, Tennessee, 1996.

Waste tested were from Oak Ridge National Laboratory MVST farm tanks W-25, W-27, and W-29. Waste was processed to remove ${ }^{137} \mathrm{Cs}$ first, ${ }^{90} \mathrm{Sr}$ second, and then ${ }^{99} \mathrm{Tc}$ using Reillex HPQ. Lambda-50 $\left(\lambda_{50}\right)$ was stated as $45 \mathrm{BV}$. Elution was performed in $7 \mathrm{BV}$ using a solution of stannous chloride, ethylenediamine, and sodium hydroxide.

c) Environmental Science \& Technology, 34, 3761-3766, Development of Bifunctional Anion-Exchange Resins with Improved Selectivity and Sorptive Kinetics for Pertechnetate: Batch-Equilibrium Experiments, Oak Ridge National Laboratory, Oak 
Ridge, Tennessee, and University of Tennessee, Knoxville, Tennessee, 2000.

Work was performed on groundwater, not directly applicable to Hanford LAW. Good technical information regarding sorption media.

d) K/TCD-1141, Removal of Technetium-99 from Simulated Oak Ridge National Laboratory Newly-Generated Liquid Low-Level Waste, Oak Ridge National Laboratory Chemical Technology Division, Oak Ridge National Laboratory, Oak Ridge, Tennessee, 1995.

The results of the work performed are not representative to LAW feed mainly due to the differences in $\mathrm{pH}$ between the Newly Generated Liquid Low-Level Waste solution, 7.4 , and LAW feed $\geq 12$. Results did show good $\mathrm{K}_{\mathrm{d}}$ for Purolite A-530E, IONAC SR-7, and Reillex HPQ.

Oak Ridge National Laboratory reviewed Reillex HPQ for ${ }^{99} \mathrm{Tc}$ removal from its NewlyGenerated Liquid Low-Level Waste. The resin was tested on two waste simulants. The simulant with the highest $\mathrm{pH}$ and salt concentrations is listed in Figure 3-3. Although the simulant has high $\mathrm{pH}$, the concentrations of the salts are too low for accurate comparison with Hanford wastes. The report states the assumption that Reillex HPQ would perform well for a high salt concentration feed matrix.

e) RPP-RPT-23199, Rev 0, The Removal of Technetium-99 from the Effluent Treatment Facility Basin 44 Waste Using Purolite A-530E, Reillex HPQ, and Sybron IONAC SR-7 Ion Exchange Resins, CH2MHill Hanford Co., Richland, Washington, 2004.

The goal of work documented here was to evaluate and compare candidate anion exchange resins for their capacity to remove ${ }^{99} \mathrm{Tc}$ from Basin 44 Reverse Osmosis (RO) reject stream. Due to the makeup of the solution processed this work is not applicable to Hanford's LAW.

f) PNNL-11386, Technetium in Alkaline, High-Salt, Radioactive Tank Waste Supernate:

Preliminary Characterization and Removal, Pacific Northwest National Laboratory, Richland, Washington, November 1997.

Work performed for this report directly supports the removal of ${ }^{99} \mathrm{Tc}$ from Hanford's LAW Immobilization feed.

The report is initial work performed by Pacific Northwest National Laboratory (PNNL) to study ${ }^{99} \mathrm{Tc}$ removal from Hanford tank waste supernate and ${ }^{99} \mathrm{Tc}$ oxidation state in the supernate. Actual SST and DST tank wastes were used.

- A composite DSSF:

- $70 \%$ from Tank AW-101;

- $20 \%$ from Tank AP-106;

- $10 \%$ from Tank AP- 102 .

- Waste from Tanks AN-107, SY-101, ANS SY-103 that are distinguished by having a high concentration of organic complexants (complexant concentrate or $\mathrm{CC}$ waste type, often referred to as LAW waste feed envelop C). 
Reillex HPQ was effective for ${ }^{99} \mathrm{Tc}$ removal from the composite DSSF waste, removing $93 \%$ on the first contact. The resin was ineffective for ${ }^{99} \mathrm{Tc}$ removal from the three $\mathrm{CC}$ wastes studied. Technetium removal from the CC wastes was in all cases less than $50 \%$. The conclusion was that to remove ${ }^{99} \mathrm{Tc}$ from these wastes, the oxidation state of the ${ }^{99} \mathrm{Tc}$ species must be adjusted to create $\mathrm{TcO} 4$ -

g) PNNL-11398, Technetium Removal Column Flow Testing with Alkaline, High Salt, Radioactive Tank Waste, Pacific Northwest National Laboratory, Richland, Washington, November 1997.

Hanford DST Waste from Tank AW-101 diluted to 5M Na with water. Waste was spiked with ${ }^{99 \mathrm{~m}} \mathrm{Tc}$ in $\mathrm{TcO}^{-}$form. The DF for recovery of ${ }^{99 \mathrm{~m}} \mathrm{Tc}$ was 1,100 ; DF of ${ }^{99} \mathrm{Tc}$ from waste was six. Waste had more non-pertechnetate fraction than estimated based on organic concentration of waste $(\sim 2.5 \mathrm{~g}$ total organic compounds $/ \mathrm{L})$

h) LA-12654, Rev., Distributions of 14 Elements on 63 Absorbers from Three Simulant Solutions (Acid-Dissolved Sludge, Acidified Supernate, and Alkaline Supernate) for Hanford HLW Tank 102-SY, Los Alamos National Laboratory, Los Alamos, New Mexico, 1994.

The alkaline simulant used for this work is slightly low in ionic strength to be directly applicable to the processing of LAW waste and removal of ${ }^{99} \mathrm{Tc}$. The simulant was based from on Tank SY-102, so it is applicable to some portion of Hanford's LAW feed. Three simulants where tested with only the alkaline solution of interest here, its matrix is shown in Figure 3-5. The results of the study with respect to ${ }^{99} \mathrm{Tc}$ and Reillex HPQ are best presented in Figure 3-6 and Figure 3-16. Elution of sorption media was not investigated.

Figure 3-16. Reillex ${ }^{\mathrm{TM}}$ HPQ Distribution Coefficients by Analyte (LA-12654 Rev.)

Table 32. Reillex ${ }^{\mathrm{IM}}$ HPQ Anion Exchange Resin: Distribution of 14 Elements from Three Simulant Solutions for Hanford Tank 102-SY

\begin{tabular}{lccrr}
\hline & & \multicolumn{3}{c}{ Kd Value for Specified Time } \\
\cline { 3 - 5 } Solution & Element & $\mathbf{3 0} \mathbf{~ m i n}$ & $\mathbf{2} \mathbf{~ h}$ & $\mathbf{6 ~ h}$ \\
\hline Alkaline & $\mathrm{Ce}$ & $<0.1$ & 0.7 & 1.0 \\
Supernate & $\mathrm{Cs}$ & $<0.1$ & $<0.1$ & $<0.1$ \\
& $\mathrm{Sr}$ & 0.4 & 0.6 & 0.6 \\
& $\mathrm{Tc}$ & 314 & 372 & 370 \\
& $\mathrm{Y}$ & 2.3 & 3.4 & 4.1 \\
& $\mathrm{Cr}$ & 0.1 & 0.2 & 0.2 \\
& $\mathrm{Co}$ & 2.2 & 2.7 & 2.7 \\
& $\mathrm{Fe}$ & 3.4 & 3.7 & 4.4 \\
$\mathrm{Mn}$ & 14 & 18 & 26 \\
& $\mathrm{Zn}$ & $<0.1$ & $<0.1$ & $<0.1$ \\
& $\mathrm{Zr}$ & 1.3 & 1.5 & 1.8 \\
& $\mathrm{U}$ & 0.2 & 0.4 & 0.7 \\
& $\mathrm{Am}$ & 4.5 & 7.5 & 21 \\
\hline \hline
\end{tabular}


i) LA-12863, Distributions of 15 Elements on 58 Absorbers from Simulated Hanford Double-shell Slurry Feed (DSSF), Los Alamos National Laboratory, Los Alamos, New Mexico, 1994.

This report is directly applicable to ${ }^{99} \mathrm{Tc}$ removal from Hanford's LAW waste stream. The study builds off of previous work performed by LANL. The simulant used is based off neutralized current acid waste (NCAW), Figure 3-8. Results for Reillex HPQ are best represented by Figure 3-9 and Figure 3-17.

Figure 3-17. Reillex ${ }^{\text {TM }}$ HPQ Distribution Coefficients by Analyte (LA-12863)

\begin{tabular}{lcrr}
\hline \hline \multicolumn{4}{c}{ Table 39. Reillex ${ }^{\mathrm{TM}}$ HPQ Anion Exchange } \\
Resin: Distribution of 15 Elements from \\
\multicolumn{4}{c}{ Simulated Hanford DSSF Solution } \\
\hline \multicolumn{4}{c}{ Kd Value for Specified Time } \\
\cline { 2 - 4 } Element & $\mathbf{3 0}$ min & $\mathbf{2 ~ h}$ & $\mathbf{6 ~ h}$ \\
\hline $\mathrm{Ce}$ & $<0.1$ & 1.2 & 7.4 \\
$\mathrm{Cs}$ & 2.4 & 0.5 & 0.5 \\
$\mathrm{Sr}$ & 2.8 & 0.7 & 0.8 \\
$\mathrm{Tc}$ & 254 & 293 & 332 \\
$\mathrm{Y}$ & 5.3 & 11 & 25 \\
$\mathrm{Cr}$ & 2.5 & 0.7 & 0.8 \\
$\mathrm{Co}$ & 1.9 & 1.1 & 1.6 \\
$\mathrm{Fe}$ & 2.5 & 1.8 & 2.3 \\
$\mathrm{Mn}$ & 4.1 & 8.5 & 12 \\
$\mathrm{Ni}$ & $<0.1$ & 2.5 & 10 \\
$\mathrm{~V}$ & 1.4 & 0.3 & 0.3 \\
$\mathrm{Zn}$ & 1.6 & 0.6 & 0.9 \\
$\mathrm{Zr}$ & 1.7 & 1.4 & 2.3 \\
$\mathrm{U}$ & 1.5 & 0.4 & $\mathbf{0 . 9}$ \\
$\mathrm{Am}$ & 3.9 & 5.7 & 10 \\
\hline \hline
\end{tabular}

j) LA-12889, Distributions of 12 Elements on 64 Absorbers from Simulated Hanford Neutralized Current Acid Waste (NCWA), Los Alamos National Laboratory, Los Alamos, New Mexico, 1994.

This report is directly applicable to 99Tc removal from Hanford's LAW waste stream. The study builds off of previous work performed by LANL. The simulant used is based off neutralized current acid waste (NCAW), Figure 3-11. Results for Reillex HPQ are best represented by Figure 3-12 and Figure 3-18. 
RPP-RPT-50122

Figure 3-18. Reillex ${ }^{\text {TM }}$ HPQ Distribution Coefficients by Analyte (LA-12889)

\begin{tabular}{lccc}
\hline \multicolumn{4}{l}{ Table 38. Reillex } \\
Resin: Distribution of 12 Enion Exchange \\
Siments from \\
Simulated Hanford NCAW Solution \\
\hline \multicolumn{4}{c}{ Kd Value for Specified Time } \\
\cline { 2 - 4 } Element & $\mathbf{3 0} \mathbf{~ m i n}$ & $\mathbf{2} \mathbf{h}$ & $\mathbf{6 ~ h}$ \\
\hline $\mathrm{Cs}$ & 0.1 & $<0.1$ & $<0.1$ \\
$\mathrm{Sr}$ & 0.2 & 0.3 & 0.3 \\
$\mathrm{Tc}$ & 382 & 459 & 445 \\
$\mathrm{Y}$ & 2.3 & 3.4 & 4.0 \\
$\mathrm{Cr}$ & $<0.1$ & $<0.1$ & $<0.1$ \\
$\mathrm{Co}$ & 0.2 & 0.2 & 0.3 \\
$\mathrm{Fe}$ & 1.1 & 1.0 & 1.0 \\
$\mathrm{Mn}$ & 1.5 & 1.9 & 2.3 \\
$\mathrm{Ni}$ & 2.2 & 2.5 & 5.1 \\
$\mathrm{~V}$ & $<0.1$ & $<0.1$ & $<0.1$ \\
$\mathrm{Zn}$ & $<0.1$ & 0.1 & 0.1 \\
$\mathrm{Zr}$ & 0.4 & 0.8 & 0.8 \\
\hline
\end{tabular}

k) WHC-SD-WM-TI-699, Rev. 1, Technical Basis for Classification of Low-Activity Waste Fraction from Hanford Site Tanks, Westinghouse Hanford Company, Richland, Washington, 1996.

The report has a section on "Technology Options" for "Technetium-99 Removal". The implementation of sorption media looked at Reillex-HPQ, eluted with $6 \mathrm{M} \mathrm{HNO3.} \mathrm{The}$ conclusion was that the method was only applicable for removal of Tc(VII), and therefore not technically feasible for their goals.

1) WHC-SD-WM-TI-718, Technetium Removal: Preliminary Flowsheet Options, Westinghouse Hanford Company, Richland, Washington, 1995.

Work document contains a preliminary investigation for flowsheets targeting the removal of ${ }^{99} \mathrm{Tc}$ from Hanford's tank wastes. Several different ${ }^{99} \mathrm{Tc}$ removal technologies were reviewed: sorption, precipitation, volatilization, and alkaline sulfide precipitation. Reillex ${ }^{\mathrm{TM}} \mathrm{HPQ}$ sorption media was selected for their flowsheet work with two eluants reviewed-1) nitric acid and 2) a solution of stannous chloride, ethylenediamine, and sodium hydroxide.

m) WSRC-MS-98-00601, Pretreatment/Radionuclide Separations of Cs/Tc from Supernates, Westinghouse Savannah River Company, Aiken, South Carolina, 1998.

The document is a brief status on separations work for Cs and ${ }^{99} \mathrm{Tc}$. The report states that an algorithm was developed to predict $\mathrm{K}_{d}$ values for Reillex HPQ regarding Hanford's supernates with values ranging from $500-600$ for most; lower for supernates containing CC. Elution was stated as requiring a strong $\mathrm{HNO}_{3}$ solution, with $8 \mathrm{M} \mathrm{HNO}_{3}$ not having complete removal. Complete elution was achieved with a Sn(II) and ethylenediamine solution. 
n) WSRC-TR-99-00317, Qualification of Reillex ${ }^{\mathrm{TM}}$ HPQ Anion Exchange Resin for Use in SRS Processes, William J, Crooks III, et. Al., Westinghouse Savannah River Company, Aiken, SC, 2000.

The report documents testing required for using Reillex in $\mathrm{HNO}_{3}$ solution at the DOE's Savannah River Site (SRS) for the loading of plutonium $(\mathrm{Pu})$. Therefore the data presented is not readily applicable to Hanford's LAW feed. Testing was performed to understand low temperature exotherms from the diethylbenzene $-8 \mathrm{M} \mathrm{HNO}_{3}$ reaction. A low-temperature exotherm was observed, generating nitric oxide (NO), carbon dioxide (CO2), and a mixture of mono- and dicarboxylic acids as reaction products. One conclusion is that Reillex HPQ contains a small amount of easily-oxidized material. A pretreatment process was developed to remove oxidizable constituents of the media, which showed comparable particle size distribution and $\mathrm{Pu}$ loading performance. Since $\mathrm{TcO}_{4}{ }^{-}$is elutable from Reillex HPQ with $8 \mathrm{M}$ HNO3, it may be applicable for understanding the safety of the system during elution and the number of time the sorption media could be regenerated.

\subsubsection{TAMTM or Sn(II) Apatite Microspheres (Kurion, Inc )}

$\mathrm{TAM}^{\mathrm{TM}^{10}}$ was developed to take advantage of the properties of $\mathrm{Sn}$ (II)apatite on a sorption media base. This product is fairly new and not much literature is available for it. Both articles below concern the media ( $\mathrm{Sn}$ (II)apatite), but not in a sorption media form as presented by Kurion. Kurion replied fully to a questionnaire regarding its product. The questionnaire coupled with results from testing on more dilute solutions showing that $\mathrm{Sn}$ (II)apatite binds ${ }^{99} \mathrm{Tc}$ well to its matrix, resulted in its inclusion in this study.

\subsubsection{Overview of Literature Reports for TAM}

a) PNNL-14208, Selection and Testing of "Getters" for Adsorption of Iodine-129 and Technetium-99: A Review, Pacific Northwest National Laboratory, Richland, Washington, 2003.

The goal of this study was to identify suitable "getter" materials that can immobilize or delay the transport of anionic radionuclides (such as ${ }^{129} \mathrm{I}$ and $\left.{ }^{99} \mathrm{TcO} 4\right)$ that would be released from physically and chemically degrading waste packages. The solutions tested are not applicable to Hanford's LAW.

b) RPP-RPT-39195, Assessment of Technetium Leachability in Cement-Stabilized Basin 43 Groundwater Brine, Washington River Protection Solutions, Richland, Washington, 2009.

The solution tested was $\sim 2.1 \mathrm{M} \mathrm{Na}$, was formulated to match the anticipated Basin 43 waste from the ETF, and is not directly applicable to Hanford's LAW. The report does show $\mathrm{Sn}$ (II)apatite as having a good leach index for ${ }^{99} \mathrm{Tc}$.

\footnotetext{
${ }^{10}$ TAM products are manufactured by Kurion, Inc. of Irvine, California.
} 
RPP-RPT-50122

3.2.7 SuperLig ${ }^{\circledR} 639$ (IBC Advanced Technologies, Inc.)

Figure 3-19. SuperLig ${ }^{\circledR} 639$ Resin

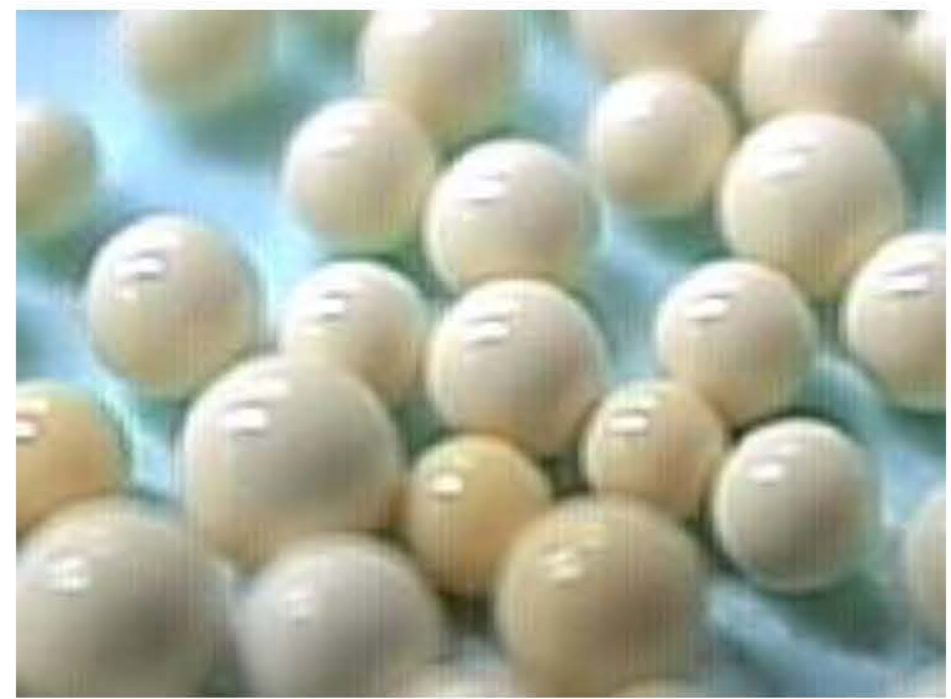

SuperLig ${ }^{\circledR 11} 639$ was selected by BNFL as the ${ }^{99} \mathrm{Tc}$ ion exchange media for the ${ }^{99} \mathrm{Tc}$ removal column as part of the Tank Waste Remediation System (TWRS now known as WTP) project. The ${ }^{99}$ removal process step was later removed with the implementation of an alternative ${ }^{99} \mathrm{Tc}$ immobilization strategy. Up to that, point SuperLig 639 was extensively tested at laboratory scale on simulants and actual waste representative of three envelopes of waste feed (A, B and C). The composition of these envelopes is found in 24590-WTP-RPT-PT-02-005, Rev 1. The key parameter of the three envelopes regarding ${ }^{99} \mathrm{Tc}$ removal is organic content. Tanks with relatively high organic content were designated as containing envelop $\mathrm{C}$ waste. Roughly $70 \%$ of the ${ }^{99} \mathrm{Tc}$ found in envelope $\mathrm{C}$ is not in the VII oxidation state, and not amenable to capture via sorption media. The SuperLig 639 resin was extensively tested at pilot scale, and its radiation resistance has also been evaluated.

The active component in the resin is a complexant specifically designed to remove ${ }^{99} \mathrm{Tc}$ in its +7 (VII) oxidation state, $\mathrm{TcO}_{4}{ }^{-}$. The beads are of sufficiently high density such that they do not float in media 1.25 to $1.27 \mathrm{~g} / \mathrm{cc}$.

The resin has been tested at lab scale and pilot scale. Key findings are:

- The resin shows a high removal efficiency, with $\mathrm{K}_{\mathrm{d}} \mathrm{s}$ in the order of 400 being routinely achieved for $\mathrm{TcO}_{4}{ }^{-}$;

- Sorption is best accomplished in the temperature range of $5^{\circ} \mathrm{C}$ to $40^{\circ} \mathrm{C}$ as the binding constant decreases with increased temperature;

- Processing rate is at $0.05 \mathrm{BV}$ per min for $>99 \%{ }^{99} \mathrm{Tc}$ removal (as is washing and elution). Increasing this rate leads to early break through;

- The resin met the average $>80 \%$ removal criteria for WTP LAW Vitrification feed;

- Elution requires approximately $10-15 \mathrm{BV}$ at a flow rate of $0.1 \mathrm{BV}$ per minute;

\footnotetext{
${ }^{11}$ SuperLig products are manufactured by IBC Advanced Technologies, Inc., of American Fork, Utah.
} 
- There must be sufficient counter ions to the $\mathrm{TcO}_{4}{ }^{-}$anion $\left(\mathrm{Na}^{+} \mathrm{K}^{+}\right.$or $\left.\mathrm{H}^{+}\right)$present in the solution;

- Early trials suggested that the initial performance degradation of the resin begin with exposure levels of $1 \times 10^{7} \mathrm{Rads}$; Further trials indicated that the resin was resistant to significant damage at $1 \times 10^{8}$ Rads, which is consistent with SuperLig 644 and polystyrene resins in general;

- Selectivity over hydroxide, chloride, fluoride, and bromide is nearly infinite. Selectivity over 2-3 $\mathrm{M}$ nitrate $\left(\mathrm{NO}_{3}{ }^{-}\right)$and $\left(\mathrm{NO}_{2}{ }^{-}\right)$nitrite is of multiple orders of magnitude, such that there is minimal effect on $\mathrm{TcO}_{4}{ }^{-}$binding up for Hanford's $\mathrm{LAW}$;

\subsubsection{Overview of Literature Reports for SuperLig ${ }^{\circledR} 639$}

a) BNF-003-98-0140, Evaluation of SuperLig® 639 Ion Exchange Resin for the Removal of Rhenium from Hanford Envelope A Simulant, Westinghouse Savannah River Company, Aiken, South Carolina, 2000.

This report showed 90 to $150 \mathrm{BV}$ to $50 \%$ breakthrough when the flow rate was in the correct range, demonstrating again the need for the correct flow rate. The elution is accomplished to $0.1 \mathrm{C} / \mathrm{Co}$ at $16 \mathrm{BV}$. The column bed design in this test had too much head space. The report included important statements such as "Tests highly successful in demonstrating effectiveness of this method for removing TcO4- from Hanford Tank Waste"; "No significant problems encountered which would prevent use of this resin as planned"; "No observations of cracking or swelling of the resin bed" are made.

b) BNF-003-98-0146, Rev. 1, Small-Scale Ion Exchange Removal of Cesium and Technetium From Hanford Tank 241-AN-103, Westinghouse Savannah River Company, Aiken, South Carolina, 2000

Waste from tank AN-103 is designated as WTP envelop A feed. The Tc $\mathrm{K}_{\mathrm{d}}$ reported was $471+/-35 \mathrm{ml} / \mathrm{g}, \lambda_{50}$ was estimated at $221+/-16 \mathrm{BV}$, and $>97 \%$ removal of Tc was achieved. When the lead column breakthrough was $47 \%(270 \mathrm{BV})$ the corresponding lag column had $8 \%$ breakthrough - assumed to be due to resin floating in lag column.

c) BNF-003-98-0219, Small-Scale Ion Exchange Removal of Cesium and Technetium from Hanford Tank 241-AN-102, Westinghouse Savannah River Company, Aiken, South Carolina, 2000.

This report concerns Envelope $\mathrm{C}$ feeds with very high organics and very low $\mathrm{TcO}_{4}{ }^{-}$ percentages of the ${ }^{99} \mathrm{Tc}$ present. This report confirms that only the $\mathrm{TcO}_{4}{ }^{-}$will be removed as per the design of the ligand of the SuperLig 639 resin.

d) BNF-003-98-0230, Intermediate-Scale Ion Exchange removal of Technetium from Savannah River Site Tank 44 F Supernate Solution, Westinghouse Savannah River Company, Aiken, South Carolina, 2000.

The solution tested was chosen to due to its similarity to Hanford LAW envelope A feed. This report is applicable to ${ }^{99} \mathrm{Te}$ removal from Hanford's LAW. The results of this work are best summarized by Figure 3-20. Testing was performed using one column with the goal of determining $45 \%$ breakthrough, which required $\sim 500 \mathrm{BV}$. 
Figure 3-20. Batch Contact Data (BNF-003-98-230)

\begin{tabular}{|l|l|l|}
\hline SuperLig ${ }^{\otimes}$ 639 K Measurements & \\
\hline ICP-MS Analysis & & \\
\hline Resin Batch \#981015DHC720011 & \\
\hline Sample \# & SRS-1 & SRS-1-D \\
\hline ADS \# & 300132736 & 300132737 \\
\hline Solution Mass (g) & 15.94 & 16.22 \\
\hline Resin Mass (g) & 0.1217 & 0.1201 \\
\hline Solution Volume (mL) & 13.28 & 13.52 \\
\hline Initial Tc Conc. (mg/L) & 3.09 & 3.09 \\
\hline Final Tc Conc. (mg/L) & 0.3274 & 0.32567 \\
\hline Kd (mL/g) & 932.8 & $\mathbf{9 6 7 . 5}$ \\
\hline solution volume/exchanger mass & 109.15 & 112.55 \\
\hline Shake Time (hrs) & $\mathbf{2 4 . 0}$ & \\
\hline Temperature (C) & $27-28$ & \\
\hline Average Kd (mL/g) & 950.1 & \\
\hline & & \\
\hline \% Tc removal & 89.4 & 89.5 \\
\hline average \% Tc removal & 89.4 & \\
\hline & & \\
\hline Feed & & \\
\hline Sample & SRS-1-FD & \\
\hline ADS \# & 300132738 & \\
\hline Tc-99 mg/L & 3.09 & \\
\hline
\end{tabular}

e) BNFL-RPT-009, Rev 0, Ion Exchange Distribution Coefficients for 137Cs and 99Tc removal from Hanford Tank Supernatants $A W-101$ (Envelope $A$ ) and $A N-107$ (Envelope $C$ ), Pacific Northwest Laboratory, Richland, Washington, 1999.

Results from a Tank AN-107 sample show that SuperLig 639 is not effective at capturing ${ }^{99} \mathrm{Tc}$ present in forms other than the $\mathrm{TcO}_{4}{ }^{-}$form (as stated by the supplier). The analysis stated that $75-78 \%$ of the $\mathrm{Tc}$ in the Tank $\mathrm{AN}-107$ solution was not in the $\mathrm{TcO}_{4}{ }^{-}$form. The analysis also determined that approximately $2.9 \%$ of the ${ }^{99} \mathrm{Tc}$ in the Tank AW-101 sample was not in the $\mathrm{TcO}_{4}{ }^{-}$form. The reported $\mathrm{K}_{\mathrm{d}}$ values from the Tank $\mathrm{AW}-101$ sample were 450 $-500 \mathrm{ml} / \mathrm{g}$. 
RPP-RPT-50122

Figure 3-21. ${ }^{99} \mathrm{Tc} \mathrm{K}_{\mathrm{d}} \mathrm{s}$ for SuperLig ${ }^{63} 63$ for Tank AW-101 Waste (BNFL-RPT-009)

\begin{tabular}{|c|c|c|c|c|c|c|c|c|c|c|}
\hline & \multicolumn{10}{|c|}{ SL-539 \& AW-101 } \\
\hline Sample ID & W39 & W39-R & W39-D & W39-D-R & W39-S1 & W39-S1-R & W39-S1D & W39-S2 & W39-S2-R & W39-S2D \\
\hline Average Temperature $\left[{ }^{\circ} \mathrm{C}\right]$ & 21 & 21 & 21 & 21 & 21 & 21 & 21 & 21 & 21 & 21 \\
\hline IVlass of Exchanger [g] & 0.0499 & 0.0499 & 0.0509 & 0.0509 & 0.0510 & 0.0510 & 0.0491 & 0.0532 & 0.0502 & 0.0504 \\
\hline Mass of AW-101 [g] & 6.6903 & 6.6903 & 6.7034 & 6.7034 & 6.5986 & 6.5986 & 6.5231 & 6.5587 & 6.5587 & 6.6921 \\
\hline $\begin{array}{l}\text { Avg. Densicy of AW-101 } \\
{[\mathrm{g} / \mathrm{mL}]}\end{array}$ & 1.3176 & 1.3176 & 1.3176 & 1.3176 & 1.3176 & 1.3176 & 1.3176 & 1.3176 & 1.3176 & 1.3176 \\
\hline Volume of AW-101 Taken [mL] & 5.0776 & 5.0776 & 5.0876 & 5.0876 & 5.0080 & 5.0080 & 4.9507 & 4.9778 & 4.9778 & 5.0790 \\
\hline F-Factor & 0.9855 & 0,9855 & 0.9855 & 0.9855 & 0.9855 & 0.9855 & 0.9855 & 0.9855 & 0.9855 & 0.9855 \\
\hline Init. ICP "Tc Conc. [ng/mL] & 268.7 & 266.0 & 268.7 & 266.0 & 2070.0 & 2070.0 & 2070.0 & 7820.0 & 7820.0 & 7820.0 \\
\hline Initial Dilution Factor & 20.0 & 20.5 & 20.0 & 20.5 & 20.0 & 20.0 & 20.0 & 20.0 & 20.0 & 20.0 \\
\hline Initial ${ }^{9}$ T c Cone [ng/mL] & 5373.3 & 5460.2 & 5373.3 & 5460.2 & 41400.0 & 41400.0 & 41403.0 & 156400.0 & 156400.0 & 156400.0 \\
\hline Initial "Ic Conc. [M] & $5.43 \mathrm{E}-05$ & $5.52 \mathrm{E}-\mathrm{C5}$ & $5.43 \mathrm{E}-05$ & $5.52 \mathrm{E}-05$ & $4.18 \mathrm{E}-04$ & $4.18 \mathrm{E}-04$ & $4.18 \mathrm{E}-04$ & $1.58 \mathrm{E}-03$ & $1.58 \mathrm{E}-03$ & $1.58 \mathrm{E}-03$ \\
\hline $\begin{array}{l}\text { Initial }{ }^{99} \text { c Conc } \mathrm{Ci} / \mathrm{m}^{3} \\
(\mathrm{uCi} / \mathrm{mL})\end{array}$ & $9.13 \mathrm{E}-02$ & $9.28 \mathrm{E}-\mathrm{C} 2$ & $9.13 \mathrm{E}-02$ & $9.28 \mathrm{E}-02$ & $7.04 \mathrm{E}-01$ & $7.04 \mathrm{E}-01$ & $7.04 \mathrm{E}-01$ & 2.66 & 2.66 & 2.66 \\
\hline $\mathrm{NO}_{3}$ concentration, $\mathrm{M}$ & 1.99 & 1.99 & 1.99 & 1.99 & 1.99 & 1.99 & 1.99 & 1.99 & 1.99 & 1.99 \\
\hline Initial $\mathrm{NO}_{3}:{ }^{4 / T} \mathrm{Tc}$ & $3.67 \mathrm{E}+04$ & $3.61 \mathrm{E}+04$ & $3.67 \mathrm{E}+\mathrm{CA}$ & $3.61 \mathrm{E}+04$ & $4.76 \mathrm{~F}+0.3$ & $4.76 \mathrm{E}+03$ & $4.76 \mathrm{E}+03$ & $1.26 \mathrm{E}+03$ & $1.26 \mathrm{E}+03$ & $1.26 \mathrm{E}+03$ \\
\hline Initial $\mathrm{NO}_{3}: \mathrm{TcO}_{4}^{-}$ & $3.78 \mathrm{E}+04$ & & & & & & & & & \\
\hline Fin $1 C P^{77} I^{\prime} c$ Conc. $[\mathrm{ng} / \mathrm{mL}]$ & 56,4 & 43.7 & 55.8 & 40.8 & 343.5 & 395.0 & 337.8 & 2039.5 & 1940.0 & 1669.0 \\
\hline Final Dilution Factor & 20.0 & 20.6 & 20.0 & 20.7 & 20.0 & 20.3 & 20.0 & 20.5 & 20.8 & 20.0 \\
\hline Final Tc Conc. [ng/mL] & 1128 & 898 & 1116 & 846 & 6870 & 7999 & 6756 & 40790 & 10283 & 33380 \\
\hline Final Tc Conc [M] & $1.14 \mathrm{E}-05$ & $9.07 \mathrm{E}-06$ & $1.13 \mathrm{E}-05$ & $8.55 \mathrm{E}-0 \mathrm{G}$ & $6.94 \mathrm{E}-05$ & 8.08F-05 & $6.82 \mathrm{~F}-05$ & $4.12 \mathrm{E}-04$ & $4.07 \mathrm{E}-04$ & $3.37 \mathrm{E}-04$ \\
\hline Final $\mathrm{NO}_{3}: 9 \mathrm{Tc}$ & $1.75 \mathrm{E}+05$ & $2.19 E+05$ & $1.77 \mathrm{E}+0.5$ & $2.33 \mathrm{E}+05$ & $2.87 \mathrm{I}+04$ & $2.46 \mathrm{E}+04$ & $2.92 \mathrm{E}+04$ & $4.83 \mathrm{E}+03$ & $4.89 \mathrm{E}-03$ & $5.90 \mathrm{E}+\mathrm{C3}$ \\
\hline $\begin{array}{l}\text { Final }{ }^{77} \mathrm{Tc} \text { Conc, } \mathrm{Cl} / \mathrm{m}^{3} \\
(\mathrm{uCi} / \mathrm{mL})\end{array}$ & $1.92 \mathrm{E}-02$ & $1.53 \mathrm{E}-02$ & $1.90 \mathrm{E}-02$ & $1.44 \mathrm{E}-02$ & $1.17 \mathrm{E}-01$ & $1.36 \mathrm{E}-01$ & 1.15E-01 & 6.93E-01 & $6.85 \mathrm{E}-01$ & $5.67 \mathrm{E}-01$ \\
\hline fraction Tc remcved & 0.79 & 0.84 & 0.79 & 0.85 & 0.83 & 0.81 & 0.84 & 0.71 & 0.74 & 0.79 \\
\hline${ }^{99} \mathrm{Tc} \mathrm{Kd}[\mathrm{mL} / \mathrm{g}]$ & 388.6 & 524.5 & 386.9 & 553.1 & 500.6 & 415.8 & 524.7 & 284.9 & 289.7 & 377.0 \\
\hline $\begin{array}{l}\text { assumed nonpertechnetate } \\
\text { fraction }\end{array}$ & 0.029 & 0.029 & 0.029 & 0.029 & $3.74 \mathrm{E}-03$ & $3.74 \mathrm{E}-03$ & $3.74 \mathrm{E}-03$ & $1.01 \mathrm{E}-03$ & $1.01 \mathrm{E}-03$ & $1.01 \mathrm{E}-03$ \\
\hline Final TCO, concentration, $\mathrm{M}$ & $9.83 \mathrm{E}-06$ & $7.48 \mathrm{E}-06$ & $9.71 \mathrm{E}-06$ & $6.96 \mathrm{E}-06$ & $6.78 \mathrm{E}-05$ & $7.92 \mathrm{E}-05$ & $6.67 \mathrm{E}-05$ & $4.10 \mathrm{E}-04$ & $4.05 \mathrm{E} .4$ & $3.36 \mathrm{E}-04$ \\
\hline Final $\mathrm{NO}_{3}: \mathrm{TCO}_{4}$ & $2.02 \mathrm{E}+05$ & $2.66 \mathrm{E}+05$ & $2.05 \mathrm{E}+05$ & $2.86 \mathrm{E}+05$ & $2.93 \mathrm{E}+04$ & $2.51 \mathrm{E}+04$ & $2.98 \mathrm{E}+04$ & $4.85 \mathrm{E}+03$ & $4.91 \mathrm{E}+03$ & $5.93 \mathrm{E}+03$ \\
\hline $\mathrm{T} \mathrm{CO}_{4} \mathrm{Kd}[\mathrm{mL} / \mathrm{g}]$ & 450.4 & 635.8 & 449.2 & 679.3 & 512.1 & 424.0 & 537.0 & 286.0 & 290.9 & 378.8 \\
\hline
\end{tabular}

f) BNFL-RPT-016 Rev 0., Small Column Testing of SuperLig 639 for Removing ${ }^{99}$ Tc From Hanford Tank Waste Envelope A (Tank 241-AW-101), Battelle, Pacific Northwest Division, Richland, Washington, 2000.

Testing reported $97 \%$ of the ${ }^{99} \mathrm{Tc}$ is removed, with the other $3 \%$ of ${ }^{99} \mathrm{Tc}$ being at lower oxidation states (note that this is in contradiction with the 15-20\% non-pertechnetate form observed in AW-101 samples used for work in PNNL-11398). The 50\% breakthrough point was reached at $213 \mathrm{BV}$ on the lead column, and $260 \mathrm{BV}$ for $60 \%$ breakthrough. The lag column performed well as a polishing column. The ${ }^{99} \mathrm{Tc}$ concentration in the product was 5.1 $\mu \mathrm{Ci} /$ liter, less than $20 \%$ of the $26.8 \mu \mathrm{Ci} /$ liter allowable (this included the $3 \%$ non- $\mathrm{TcO}_{4}{ }^{-}$ form). The maximum DF for $\mathrm{TcO}_{4}{ }^{-}$only is reported as 433 . The eluent used for this work was not the WTP planned eluent -- this work used $0.5 \mathrm{M} \mathrm{HNO}_{3}$ and led to a long, drawn out elution. The column design was also poor with undesired head space leading to large volumes of working solutions to clean the column of $\mathrm{Al}, \mathrm{Na}, \mathrm{K}$, etc. from the feed. Despite the less than optimum configuration and procedure, data ${ }^{99} \mathrm{Tc}$ is effectively removed from the Envelope A tank waste.

g) BNFL-RPT-022, Rev. 0, Small Column Testing of SuperLig 639 for Removing 99Tc from Hanford Tank Waste Envelop C (Tank 241-AN-107), Battelle, Pacific Northwest Division, Richland, Washington, 2000. 
The report states that $65 \%$ to $87 \%$ of $\mathrm{TcO}_{4}{ }^{-}$is removed by tracking the ${ }^{95 \mathrm{~m}} \mathrm{TcO}_{4}{ }^{-}$tracer, however review of total ${ }^{99} \mathrm{Tc}$ removed showed only $11 \%$ to $22 \%$ removal; indicating that envelope $\mathrm{C}$ wastes (containing $\mathrm{CC}$ ) exhibit poor ${ }^{99} \mathrm{Tc}$ removal using sorption media.

h) BNFL-RPT-0028 Rev 0, Analysis of Spent Ion Exchange Media: SuperLig ${ }^{\circledR} 639$ and SuperLig ${ }^{\circledR}$ 644, Battelle, Pacific Northwest Division, Richland, Washington, 2000

The report identifies residual amounts of components on resins after loading and elution tests to support disposition of the spent resin. The SuperLig 639 had two elements above the minimum reportable quantities, ${ }^{99} \mathrm{Tc}$ and $\mathrm{K}$, despite the fact that the elution was only run at $50{ }^{\circ} \mathrm{C}$ with a feed that had significant $\mathrm{K}$ present. These conditions led to the elution being reported as less than optimal.

i) SRTC-BNFL-013 Rev 0, Evaluation of the Radiation Stability of SuperLig ${ }^{\circledR}$ 639, Westinghouse Savannah River Company, Aiken, South Carolina, 1997.

Testing performed exposed SuperLig 639 to a cobalt $60\left({ }^{60} \mathrm{Co}\right)$ gamma source for evaluation of loss in effectiveness. The data reported in this report are more than an order of magnitude better than previously reported. According to this report, no degradation occurs until the SuperLig $^{\circledR} 639$ sees $1 \times 10^{8}$ Rads; $50 \%$ degradation occurs at $1 \times 10^{8}$ Rads; and $90 \%$ at $1 \times$ $10^{9}$ Rads. Based on this data alone, these results would give a significantly longer life than even that BNFL which was proposing. If ${ }^{137} \mathrm{Cs}$ where not to be removed prior to ${ }^{99} \mathrm{Tc}$ removal SuperLig 639 degradation would be similar to that of SuperLig ${ }^{\circledR} 644$; since ${ }^{99} \mathrm{Tc}$ removal will be post ${ }^{137} \mathrm{Cs}$ removal, degradation of the resin due to radiation is improbable.

j) WSRC-MS-2000-00499, Comprehensive Scale Testing of the Ion Exchange Removal of Cesium and Technetium from Hanford Tank Wastes, CH2MHill Hanford Group, Richland, Washington, 2000.

Lab and pilot scale removal of ${ }^{99} \mathrm{Tc}$ or rhenium (Re) (as ${ }^{99} \mathrm{Tc}$ simulant) from Tank AN-103 waste and a Tank AN-105 simulant was performed. Flow rate is shown to be important to proper removal. When the flow rates exceed 7 column volumes $(\mathrm{CV})$ per hour (exceeding the optimal $0.1 \mathrm{CV} /$ minute), breakthrough occurs early. However, when the flow rates are in the correct range, loading volumes to $50 \%$ breakthrough are in the $100 \mathrm{~s}$ of BV. The report also states that the results (under the proper flow rates) met all conditions required at Hanford. In addition, the report states that the $\mathrm{NO}_{3}{ }^{-}$to $\mathrm{TcO}_{4}{ }^{-}$ratio is higher than that expected at Hanford, and that these results may not apply to even higher $\mathrm{NO}_{3}{ }^{-}$to $\mathrm{TcO}_{4}{ }^{-}$ratios. The one negative is that this test was done prior to increasing the density of the SuperLig 639 so that it would not float. Therefore, it is mentioned that floating of the resin may affected the sharpness of the curve. Also, the early ${ }^{99} \mathrm{Tc}$ polishing was not quite as high as in the batch equilibrium tests. 
k) WSRC-MS-2001-00573, SuperLig ${ }^{\circledR} 639$ Equilibrium Sorption data for Technetium from Hanford Tank Waste Supernates, Westinghouse Savannah River Company, Aiken, South Carolina, 2001.

Pertechnetate \% removals calculated for the initial contacts were approximately 87,91 , and $89 \%$ for the AN-103, AZ-102, and AN-102 samples, respectively. For the AN-102 sample, the $\%$ removal for total technetium for the initial contact was $<30 \%$, due to the fact that $\sim 60 \%$ of the $99 \mathrm{Tc}$ was not TcO4-. The lower loadings observed for the AZ-102 sample indicates that resin performance varies directly with the ionic strength of the solution (AZ102 had a roughly half the amount of $\mathrm{Na}$ in solution; resin performance increases with increasing ionic strength of the solution). The Kd values for Hanford tank wastes AN-103, $\mathrm{AZ}-102$, and $\mathrm{AN}-102$ were 530,886 , and $287 \mathrm{~mL} / \mathrm{g}$, respectively

Table 3-8. Concentrations of Selected Analytes in the Hanford Tank Waste Supernates (WSRC-MS-2001-00573)

\begin{tabular}{|c|c|c|c|}
\hline Sample & $\begin{array}{c}\text { Equilibrium } \mathrm{TcO}_{4}{ }^{-} \\
(\mathrm{M})\end{array}$ & $\begin{array}{c}\mathrm{TcO}_{4}^{-} \mathrm{K}_{\mathrm{d}} \\
(\mathrm{mL} / \mathrm{g})\end{array}$ & $\begin{array}{c}\mathrm{TcO}_{4}^{-} \text {loading } \\
(\mathrm{mmol} / \mathrm{g})\end{array}$ \\
\hline \multicolumn{4}{|c|}{ Tank AN-103 } \\
\hline Spike & $4.24 \mathrm{E}-05$ & 452 & $1.92 \mathrm{E}-02$ \\
\hline Initial contact & $3.93 \mathrm{E}-06$ & 530 & 2.06 E-03 \\
\hline $1^{\text {st }}$ Recontact & $4.86 \mathrm{E}-07$ & 714 & 3.46 E-04 \\
\hline $2^{\text {nd }}$ Recontact & 8.95 E-08 & 459 & $4.08 \mathrm{E}-05$ \\
\hline \multicolumn{4}{|c|}{ Tank AZ-102 } \\
\hline Initial contact & $1.43 \mathrm{E}-05$ & 886 & $1.27 \mathrm{E}-02$ \\
\hline $1^{\text {st }}$ Recontact & $1.21 \mathrm{E}-06$ & 982 & $1.17 \mathrm{E}-03$ \\
\hline $2^{\text {nd }}$ Recontact & $1.62 \mathrm{E}-07$ & 548 & $7.98 \mathrm{E}-05$ \\
\hline $3^{\text {rd }}$ Recontact & $1.72 \mathrm{E}-08$ & 1109 & $1.11 \mathrm{E}-05$ \\
\hline \multicolumn{4}{|c|}{ Tank AN-102 } \\
\hline Spike & $6.39 \mathrm{E}-05$ & 288 & 1.83 E-02 \\
\hline Initial contact & 5.14 E-06 & 281 & 1.43 E-03 \\
\hline $1^{\text {st }}$ Recontact & $1.21 \mathrm{E}-06$ & $332^{*}$ & 4.03 E-04 \\
\hline $2^{\text {nd }}$ Recontact & $2.00 \mathrm{E}-06$ & NA & NA \\
\hline
\end{tabular}

* Value calculated from a single batch contact experiment rather than the average of duplicate experimental results. $\mathrm{NA}=$ not applicable; $\mathrm{K}_{\mathrm{d}}$ and loading values were not calculated for this experiment because the data indicated that no technetium was adsorbed to the resin. 
1) WSRC-MS-2001-00760, Technetium Removal from Hanford and Savannah River Site Actual Tank Waste Supernates with SuperLig 639 Resin, Westinghouse Savannah River Co., Aiken, South Carolina, 2001.

${ }^{99} \mathrm{Tc}$ was removed prior to removal of ${ }^{137} \mathrm{Cs}$ with SuperLig 644. The AN-103 sample, lead/lag column configuration, had ${ }^{99} \mathrm{Tc}$ removal of $92.6 \%$ (DF of 13.5). Analysis showed that SuperLig 639 extracts ${ }^{99} \mathrm{Tc}$ as an ion pair (KTcO4 or NaTcO4). Several issues where observed that resulted in data scatter, beads floating and column diameter less than optimal (due to amount of solution available for elution).

Comparison of the breakthrough data for a Savannah River sample from tank 44F verses the AN-103 sample (containing comparable sodium and pertechnetate concentrations) showed that SuperLig 639 had twice the capacity for Tank 44F solution, see table XXX. Either tank $44 \mathrm{~F}$ 's elevated $\mathrm{OH}$ - level and/or low nitrate concentration in this sample resulted in significantly enhanced pertechnetate removal.

Table 3-9. Hanford AN-103 vs. Savannah River 44F (extracted from WSRC-MS-200100760)

\begin{tabular}{|c|c|c|}
\hline Analyte & Tank 44F & Tank AN-103 \\
\hline $\mathrm{Na}^{+}$ & $5.4 \mathrm{M}$ & $4.99 \mathrm{M}$ \\
\hline $\mathrm{NO}_{3}{ }^{-}$ & $0.495 \mathrm{M}$ & $0.998 \mathrm{M}$ \\
\hline $\mathrm{OH}^{-}($free $)$ & $4.5 \mathrm{M}$ & 1.87 \\
\hline${ }^{99} \mathrm{Tc}$ & $3.13 \mathrm{E}-5$ & $3.07 \mathrm{E}-5$ \\
\hline$\sim 45 \%$ Breakthrough & $580 \mathrm{BV}$ & $270 \mathrm{BV}$ \\
\hline
\end{tabular}

m) WSRC-MS-2003-00789, Multiple Ion Exchange Column Tests for Technetium Removal from Hanford Tank Waste Supernate $(U)$, Westinghouse Savannah River Company, Aiken South Carolina, 2003.

This report presents the results of ${ }^{99} \mathrm{Tc}$ removal from Tank AW-101 waste through five cycles of loading. The average ${ }^{99} \mathrm{Tc}$ loading for the cycles was $250 \mathrm{BV}$ at $10 \%$ breakthrough. Removal of ${ }^{99} \mathrm{Tc}$ was greater than $99.4 \%$, and $99 \%$ of the ${ }^{99} \mathrm{Tc}$ loaded on the resin was elutable with less than $15 \mathrm{BV}$ of de-ionized water at $65^{\circ} \mathrm{C}$.

n) WSRC-MS-2003-00792, Column Performance Testing of SuperLig ${ }^{\circledR} 639$ Resin with Simulated Hanford Waste Supernates: Identification of the Primary Sorbing Species and Detailed Characterization of Their Desorption Profiles, Savannah River Technology Center, Westinghouse Savannah River Company, Aiken, South Carolina, 2003.

Envelope A and B simulants show Re loaded well with over $200 \mathrm{BV}$ to $50 \%$ breakthrough. The envelope $\mathrm{C}$ (containing organics) simulant resulted in lower ${ }^{99} \mathrm{Tc}$ oxidation states and subsequently poorer resin loading. Elution with hot water worked well with removal of potassium nitrate $\left(\mathrm{KNO}_{3}\right)$ harder than sodium nitrate $\left(\mathrm{NaNO}_{3}\right)$; also potassium perrhenate $\left(\mathrm{KReO}_{4}\right)$ eluted later than sodium perrhenate $\left(\mathrm{NaReO}_{4}\right)$. The manufacturer, IBC Advances Technologies, Inc., has stated that potassium (K) salts bind more strongly and require elution 
with higher temperature water. The presence of $\mathrm{K}$ led to more $\mathrm{Re}\left({ }^{99} \mathrm{Tc}\right)$ binding and not less. The data on the elution in this paper shows why elution with hot water is necessary. It is not a selectivity problem, rather a stronger equilibrium constant involved -- when $\mathrm{K}$ is present the $\mathrm{KTcO}_{4}$ simply becomes the strongest binder. Roughly the same selectivity for $\mathrm{KTcO}_{4}$ over $\mathrm{KNO}_{3}$ exists as for $\mathrm{NaTcO}_{4}$ over $\mathrm{NaNO}_{3}$, etc.

o) WSRC-TR-2000-00302, Summary of Testing of SuperLig ${ }^{\circledR} 639$ at the TFL Ion Exchange Facility, Savannah River Technology Center, Westinghouse Savannah River Company, Aiken, South Carolina, 2000.

This was pilot scale testing, designed to reach $\lambda_{50}$ at $100 \mathrm{BV}$. The lead column removed $72 \%$ of the perrhenate, $24 \%$ was removed from the lag column. The simulant was at $18^{\circ} \mathrm{C}$, modeling AN-105 waste. Data was obtained was used to assess the VERSEion exchange computer model which was to be used for design and optimization of WTP Tc removal facility. All runs exceeded $100 \mathrm{BV}$ to $50 \%$ breakthrough, and DF was as high as 300 .

p) WSRC-TR-2000-00303, Rev 0, Demonstration of an Ion Exchange Resin Addition/Removal System with SuperLig ${ }^{\circledR}$ 659, Westinghouse Savannah River Company, Aiken, South Carolina, 2000.

This report focuses on testing the design of the ${ }^{99} \mathrm{Tc}$ removal media slurry system for the WTP. It utilizes SuperLig 659 in lieu of SuperLig 639 due to resin availability. The report is not directly applicable to efficiency of SuperLig 639 for ${ }^{99} \mathrm{Tc}$ removal, but would aid in the development of a removal system.

q) WSRC-TR-2000-00305, Preliminary Ion Exchange Modeling for Removal of Technetium from Hanford Waste Using SuperLig ${ }^{\circledR} 639$ Resin, Westinghouse Savannah River Company, Aiken, South Carolina, 2000.

Very comprehensive report for ion exchange as it would be implemented by WTP. The report is a represents a status on regarding the modeling of technetium removal using SuperLig 639. Twenty bench-scale column tests and approximately 88 batch equilibrium experiments are addressed. Data was also used to quantify the offset between Re and Tc.

r) WSRC-TR-2000-00419, Rev 0, Small-Scale Ion Exchange Removal of Cesium and Technetium form Envelope B Hanford Tank 241-AZ-102, Westinghouse Savannah River Company, Aiken, South Carolina, 2001.

Testing resulted in $170 \mathrm{BV}$ on the lead column with a breakthrough of $9.8 \%$. Breakthrough of $50 \%$ was projected to occur at $450 \mathrm{BV}$. Removal rate was $99.97 \%$ with a polishing column at over $127 \mathrm{BV}$. Elution was performed with water at room temperature elution, leading to higher than normal elution volumes.

s) WSRC-TR-2000-00420, Intermediate-Scale Ion Exchange Removal of Cesium and Technetium from Hanford Tank 241-AN-102, Westinghouse Savannah River Company, Aiken, South Carolina, 2000.

This report is about Envelope $\mathrm{C}$ feeds containing high organics and very low $\mathrm{TcO}_{4}{ }^{-}$ percentages of the ${ }^{99} \mathrm{Tc}$ present. It confirms that only the $\mathrm{TcO}_{4}{ }^{-}$will be removed as per the design of the ligand of the SuperLig 639 resin. 
t) WSRC-TR-2000-00424, Rev 0, Tank 241-AZ-102 SuperLig@639 Technetium Ion Exchange Eluate Evaporation Study, Westinghouse Savannah River Company Aiken, South Carolina, 2000 .

This report deals with the eluent from the SuperLig 639 after the separation. It shows that with eluent containing only water plus dilute $\mathrm{NaOH}$ (from the wash) and a little $\mathrm{NaNO}_{3}$, the ${ }^{97} \mathrm{Tc}$ volatilizing in an evaporator is not an issue. This problem is mentioned specifically with other competing technologies that have to use at least some $\mathrm{NO}_{3}{ }^{-}$in the elution. This result is a specific example of an advantage to the SuperLig 639 beyond its performance in ${ }^{92}$ Tc removal itself.

u) WSRC-2002-TR-00495, Rev 0, Evaluating the Effects of Tri-Butyl Phosphate (TBP) and Normal Paraffin Hydrocarbon (NPH) in Simulated Low-Activity Waste Solution on Ion Exchange, Savannah River Technology Center, Westinghouse Savannah River Company, Aiken, South Carolina, 2002.

The solution was a WTP Envelope B AZ-101 filtrate simulant which had been used in ultrafiltration work using Re as a surrogate for ${ }^{99} \mathrm{Tc}$. Two variations on the simulant were used: Simulant 0 - was the baseline filtrate, and Simulant $\mathrm{H}$ - was spiked with organics resulting in $2500 \mu \mathrm{g} / \mathrm{ml}$ tri-butyl phosphate (TBP) and $2500 \mu \mathrm{g} / \mathrm{mL}$ of normal paraffin hydrocarbon $(\mathrm{NPH})$. No statistical difference in the performance of SuperLig 639 to remove ${ }^{9}$ Tc was observed between the simulants - either batch contact $\lambda$ values or column loading $\lambda$ values. This work shows that the presents of organics by itself is not an indicator of ${ }^{99} \mathrm{Tc}$ (pertechnetate) removal effectiveness.

WSRC-TR-2003-00098, Rev 1, Multiple Ion Exchange Column Runs for Cesium and Technetium Removal from $A W-101$ Waste Sample $(U)$, Savannah River National Laboratory, Westinghouse Savannah River Company, Aiken, South Carolina, 2004. Approximately 250 BV of AW-101 of solution was processed at $<10 \%$ breakthrough of ${ }^{99} \mathrm{Tc}$. The percent of ${ }^{92} \mathrm{Tc}$ (pertechnetate) removal was $>99.94 \%$ (DF of about 1700 ) for each of the five cycles. Approximately $99 \%$ of the ${ }^{99} \mathrm{Tc}$ was eluted from resin in $<15 \mathrm{BV}$ using de-ionized water at $65^{\circ} \mathrm{C}$

Figure 3-22. Equilibrium Distribution Coefficient Table for Tc Removal (WSRC-TR-200300098, Rev 1)

Tahle 4-2. $K_{d}$ s for Technetium in AW-101 Actual Waste Sample

\begin{tabular}{|l|c|c|c|c|c|c|}
\hline $\begin{array}{c}\text { AW-101 Actual Waste } \\
\text { Sample ID }\end{array}$ & $\begin{array}{c}\text { phase ratio, } \\
\mathbf{m L} / \mathbf{g}\end{array}$ & $\begin{array}{c}\left.{ }^{99} \mathbf{T c}\right]_{0} \\
(\mu \mathrm{Ci} / \mathbf{m L})\end{array}$ & $\begin{array}{c}\left.{ }^{99} \mathbf{T c}\right]_{0} \\
(\mu \mathrm{Ci} / \mathbf{m L})\end{array}$ & $\begin{array}{c}\mathrm{K}_{\mathrm{d}} \\
(\mathbf{m L} / \mathbf{g})\end{array}$ & $\begin{array}{c}\text { avg. } \mathbf{K}_{\mathbf{d}} \\
(\mathbf{m L} / \mathbf{g})\end{array}$ & \% RSD \\
\hline NH39-AW101-Kd-1 & 96 & 4725 & 492 & 839 & ma & na \\
\hline NH39-AW101-Kd-1D & 90 & 4725 & 508 & 766 & 802 & 6.4 \\
\hline NH39-AW101-Kd-2 & 9.5 & 4725 & 190 & 231 & na & na \\
\hline NH39-AW101-Kd-2D & 9.5 & 4725 & 181 & 245 & 238 & 4.1 \\
\hline
\end{tabular}

na $=$ not applicable 
Figure 3-23. Breakthrough Curves for SuperLig 639 on AW-101 Waste (WSRC-TR-200300098, Rev 1)

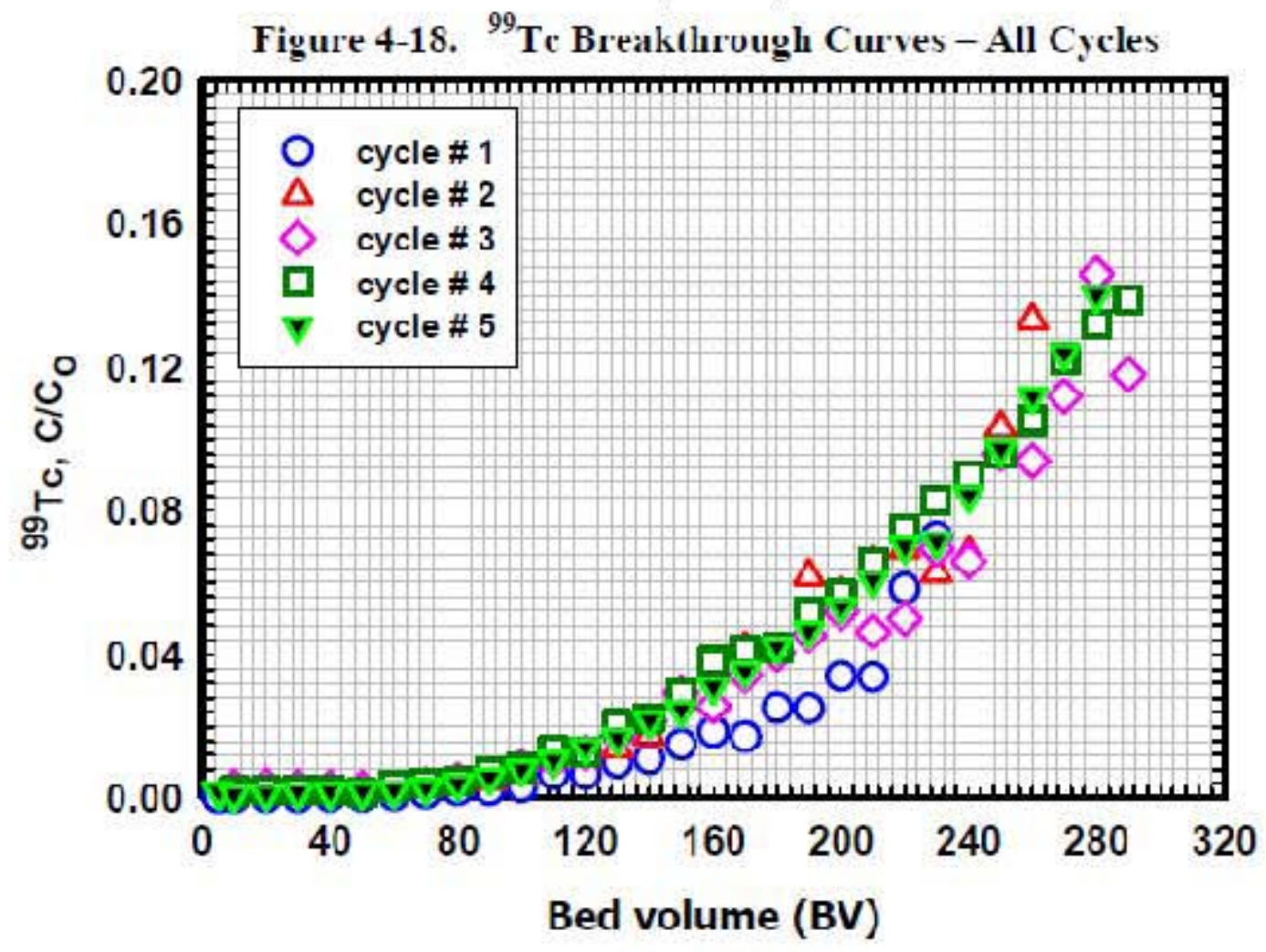

v) WTP-RPT-024, Rev 0 (PNWD-3239), Radiation Stability Testing of SuperLig(B639 and SuperLig(044 Resins, Battelle, Pacific Northwest Division, Richland, Washington, 2003.

No change in the SL-639 Tc batch-equilibrium coefficient was observed until it was exposed to doses of greater than $10^{7} \mathrm{R}$, and the changes were relatively minor even up to $10^{8} \mathrm{R}$. This result is similar to that reported in the previous radiolysis study by Oji (SRTC-BNFL-013). Concentrations of benzene, toluene and xylene VOCs positively identified in the gases generated from the SL- 639 resin increased with increasing temperature but there was no trend with dose. On the basis of the results from this report, the resin would only begin to show signs of deterioration in performance after 10,700 or 8,770 cycles processing envelope $A$ or B LAW, respectively.

w) WTP-RPT-030, Rev 0, Small Column Testing of SuperLig@ 639 for Removing ${ }^{99}$ Tc from Hanford Tank Waste Envelope A (Tank 241-AP-101), Battelle, Pacific Northwest Division, Richland, Washington, 2002.

Tank 241-AP-101 dilute feed is treated to remove ${ }^{99} \mathrm{Tc}$ on leaditrail system. $220 \mathrm{BV}$ are treated with $50.1 \mu \mathrm{Ci} /$ liter reduced to $0.477 \mu \mathrm{Ci} /$ liter, which is over $99 \%$ removal. At end of 220 BV $5.2 \%$ breakthrough of lead column and $0.5 \%$ breakthrough of lag column. An initial $\mathrm{DF}$ of 230 was reported. Analysis of the eluant shows that after $17 \mathrm{BV}$ of flushing a C/Co of 0.01 was achieved. Testing was considered a complete success. 
x) WTP-RPT-031, Rev 1, Small Column Testing of SuperLig 639 for Removing ${ }^{99}$ Tc from Hanford Tank Waste 241-AN-102 Supernate (Envelope C) Mixed with Tank 241-C-104 Solids (Envelope D) Wash and Permeate Solutions, Battelle, Pacific Northwest Division, Richland, Washington, 2004.

This report is about Envelope $\mathrm{C}$ feeds with very high organics and low $\mathrm{TcO}_{4}{ }^{-}$percentages of the ${ }^{99} \mathrm{Tc}$ present. It confirms that only the $\mathrm{TcO}_{4}{ }^{-}$will be removed as per the design of the ligand of the SuperLig 639 resin.

y) WTP-RPT-047, Rev 0, Chemical Degradation of SuperLig ${ }^{\circledR} 639$ Ion Exchange Resin, Battelle, Pacific Northwest Division, Richland, Washington, 2003.

Work performed included 26 cycles of operation of a single SuperLig 639 column with a variety of ${ }^{99} \mathrm{Tc}, \mathrm{NO}_{3}{ }^{-}$and $\mathrm{NO}_{2}^{-}$concentrations. The bed performance was hampered due to channeling for some of cycles. For this reason, not all test objectives could be met. However, data and conclusions reported show that there is no degradation by radiation or chemical attack over the 26 cycles (a result also shown by microscopic review of the resin) and no change in breakthrough curves or elution curves over the 26 cycles (other than issues with channeling). Breakthrough of $20-30 \%$ was seen at $>200 \mathrm{BV}$ in all cases where channeling was not significant. In elutions where channeling was avoided, $0.01 \mathrm{C} / \mathrm{Co}$ was obtained in 10 to $18 \mathrm{BV}$ elution. The spent resin after 26 cycles had $0.69 \mu \mathrm{g} / \mathrm{g}{ }^{99} \mathrm{Tc}$ or 5.86 $\mathrm{mCi} / \mathrm{m}^{3}$, which was reported as well below Hanford Site Solid Waste Acceptance. No toxicity issues were found in the spent resin. Nitrate and nitrite were found to compete with ${ }^{99} \mathrm{Tc}$ for resin sites.

z) WTP-RPT-058, Rev 1, Small Column Testing of SuperLig ${ }^{\circledR} 639$ for Removing ${ }^{99}$ Tc from Hanford Tank Waste Envlope B (Tank 241-AZ-101), Battelle Pacific Northwest Division, Richland, Washington, 2004.

This report shows Envelope $\mathrm{B}^{99} \mathrm{Te}$ removal from Tank AZ-101 waste. The results show the $\mathrm{K}_{d} \mathrm{~S}$ holding or increasing for increasing nitrate to $\mathrm{TcO}_{4}{ }^{-}$ratio, demonstrating the good selectivity of the resin. The $50 \%$ breakthrough point was $300+\mathrm{BV}$, and the trail column maintained $0.1 \%$ or less $\mathrm{C} / \mathrm{Co}$ for $300 \mathrm{BV}$. A $0.1 \mathrm{M} \mathrm{NaOH}$ solution was used to prepare the column for feed solution. It worked but was found to be low in total $\mathrm{Na}$ and hydroxide content for best performance. A $65^{\circ} \mathrm{C}$ de-ionized water elution was used, and the ratio of $\mathrm{TcO}_{4}{ }^{-}$remaining on the resin was at $0.1 \mathrm{C} / \mathrm{C}_{0}$ at $9 \mathrm{BV}$ elution and $0.01 \mathrm{C} / \mathrm{Co}$ at $16 \mathrm{BV}$ despite the influent having a low $\mathrm{C}_{0}$ value. Performance of work was described as "progressed without difficulties". 
RPP-RPT-50122

\section{CONCLUSION}

A literature search has been performed for work regarding the removal of ${ }^{99} \mathrm{Tc}$ from Hanford's LAW using sorption media. Past work and SMEs were used to narrow the list to a manageable number for more thorough review. For final comparison the sorption media have been split into two logical classifications -- elutable and non-elutable. Sorption media have been evaluated based on technical development, with criteria for a 10 being $100 \%$ confidence of the media and system achieving all technical performance requirements upon implementation. Safety, environmental and economic aspects of the media have not been included. Work performed and documented in the references focus on technical feasibility. Both economics and safety will ultimately play a large role in the selection of the process and sorption media to be implemented.

The goal for the team was to rank the sorption media on the same scales, and then split them into two groups. The lower scores for non-elutable sorption media largely reflect the fact that the WTP path to ${ }^{99} \mathrm{Te}$ removal required the use of elutable sorption media. Therefore, far more data exists for deployment of elutable sorption media than for non-elutable sorption media with Hanford LAW feed. Except for perhaps the case of SuperLig 639, the scores are best used as a rough guide to those sorption media that will likely perform well based on knowledge gathered to date, and not as a tool to select a final resin for implementation.

Rough rankings of elutable sorption media are outlined in 4-1. Due to previous work supporting the implementation of SuperLig 639 at WTP, it would be the clear sorption media of choice. Given that the system will not be implemented for some time, further investigation of ABEC 2000 may show it to be an equal competitor to SuperLig 639. Both SuperLig 639 and ABEC 2000 are elutable with water, making them more flexible for process flowsheet development and offering more favorable safety and environmental impacts.

Rough rankings of non-elutable sorption media are outlined in 4-2. The economic impacts of non-elutable resins may be the main driver in final selection of sorption media. However at this stage very little is known about disposal and process requirements and sorption media costs. Therefore, differentiating based on economics is omitted from this ranking. It is thought that TAM may be more environmentally safe due to its inorganic composition, resulting in less potential generation of off-gas and the likelihood of meeting long term disposal requirements. The latter result will be dependent on the disposal criteria of the repository. The real issue with all non-elutable sorption media is the lack of testing on Hanford's LAW feed. Until the ability of non-elutable resins to selectively remove and hold ${ }^{99} \mathrm{Tc}$ from a high ionic strength $(>5 \mathrm{M} \mathrm{Na})$, high $\mathrm{pH}(\geq 12)$ solution is verified, the technical scores for these media will remain below those of elutable resins, where more development has been performed. 
Table 4-1. Elutable Sorption Media

\begin{tabular}{|c|c|c|}
\hline RESIN & $\begin{array}{l}\text { TECHNICAL } \\
\text { RANK } \\
(1-10)\end{array}$ & COMMENTS \\
\hline $\mathrm{ABEC}(\mathrm{B}-2000$ & 7 & $\begin{array}{l}\text { Expected to be less expensive than SuperLig }{ }^{\circledR} 639 \text {, but less capacity per } \\
\text { load cycle, these two factors balance; Elutable with water, which is good } \\
\text { for processing (allows evaporation to concentrate); }{ }^{99} \mathrm{Tc} \text { capacity less than } \\
\text { SuperLig( } 639 \text { ), not much test data }\end{array}$ \\
\hline $\begin{array}{l}\text { DOWEX 1-X8 } \\
\text { RESIN } \\
\text { PROPERTIES }\end{array}$ & 6 & $\begin{array}{l}\text { Elution with either } 4 \mathrm{M} \mathrm{HNO}_{3} \text { or ethylene diamine solution impacts cost } \\
\text { and safety; Good }{ }^{99} \mathrm{Tc} \text { removal, but nitrate addition to process via } 4 \mathrm{M} \\
\mathrm{HNO}_{3} \text { elution adds processing issues }\end{array}$ \\
\hline Reillex HPQ & 6 & $\begin{array}{l}\text { Elutable with } 8 \mathrm{M} \mathrm{HNO}_{3} \text { or ethylene diamine solution impacts both } \\
\text { economics and safety viability }\end{array}$ \\
\hline SuperLig 639 & 9 & $\begin{array}{l}\text { Extensive testing with Hanford DST wastes; expensive resin but can be } \\
\text { reused for many cycles with reasonably high capacity per cycle; water } \\
\text { elution does not add chemicals to process; extensive testing performed on } \\
\text { Hanford's LAW }\end{array}$ \\
\hline
\end{tabular}

Table 4-2. Non-Elutable Sorption Media

\begin{tabular}{|l|c|l|}
\hline \multicolumn{1}{|c|}{ RESIN } & $\begin{array}{c}\text { TECHNICAL } \\
\text { RANK } \\
(1-10)\end{array}$ & Some testing has been performed on high pH tank waste. \\
\hline Purolite A520E & 5 & $\begin{array}{l}\text { COMMENTS } \\
\text { is below LAW pH }\end{array}$ \\
\hline Purolite A530E & 6 & $\begin{array}{l}\text { Assumes that the harsh elution environments required allow the sorption } \\
\text { media to perform as a non-elutable. }\end{array}$ \\
\hline Reillex HPQ & 5 & $\begin{array}{l}\text { Data shows it is very good at locking up }{ }^{99} \mathrm{Tc} \text {. Nearly all data is from the } \\
\text { vendor. Work has been performed regarding waste form performance. } \\
\text { Tc(VII) reduced to Tc(IV) }\end{array}$ \\
\hline $\begin{array}{l}\text { TAM - SnII Apatite } \\
\text { Microspheres }\end{array}$ & \multicolumn{2}{|l}{ Tc. Recommended operating $\mathrm{pH}$} \\
\hline
\end{tabular}


RPP-RPT-50122

\section{REFERENCES}

24590-PTF-RPT-RT-02-001, Rev 0, WTP PTF Alternative Resin Selection, Bechtel National, Inc., Richland, Washington, 2002.

24590-WTP-ICD-MG-01-019, Rev. 4, ICD 19 -Interface Control Document for Waste Feed, Bechtel National, Inc., Richland, Washington, 2008.

24590-WTP-RPT-PT-02-005, Rev 1, Flowsheet Bases, Assumptions, and Requirements, Bechtel National, Inc., Richland, Washington, 2002.

24590-WTP-RPT-PT-02-005, Rev 5, Flowsheet Bases, Assumptions, and Requirements, Bechtel National, Inc., Richland, Washington, 2009.

Atlas of Eh-pH Diagrams, Intercomparison of Thermodynamic Databases, Geological Survey of Japan Open File Report No. 419, National Institute of Advanced Industrial Science and Technology, Research Center for Deep Geological Environments, Naoto TAKENO, May, 2005.

BNF-003-98-0140, Evaluation of SuperLig ${ }^{\circledR} 639$ Ion Exchange Resin for the Removal of Rhenium from Hanford Envelope A Simulant, Westinghouse Savannah River Company, Aiken, South Carolina, 2000.

BNF-003-98-0146, Rev. 1, Small-Scale Ion Exchange Removal of Cesium and Technetium From Hanford Tank 241-AN-103, Westinghouse Savannah River Company, Aiken, South Carolina, 2000.

BNF-003-98-0219, Small-Scale Ion Exchange Removal of Cesium and Technetium from Hanford Tank 241-AN-102, Westinghouse Savannah River Company, Aiken, South Carolina, 2000.

BNF-003-98-0230, Intermediate-Scale Ion Exchange removal of Technetium from Savannah River Site Tank 44 F Supernate Solution, Westinghouse Savannah River Company, Aiken, South Carolina, 2000.

BNFL-RPT-009, Rev 0, Ion Exchange Distribution Coefficients for 137Cs and 99Tc removal from Hanford Tank Supernatants AW-101 (Envelope A) and AN-107 (Envelope C), Pacific Northwest Laboratory, Richland, Washington, 1999.

BNFL-RPT-016 Rev 0., Small Column Testing of SuperLig ${ }^{\circledR} 639$ for Removing ${ }^{99}$ Tc From Hanford Tank Waste Envelope A (Tank 241-AW-101), Battelle, Pacific Northwest Division, Richland, Washington, 2000.

BNFL-RPT-022, Rev. 0, Small Column Testing of Superlig 639 for Removing ${ }^{99}$ Tc from Hanford Tank Waste Envelop C (Tank 241-AN-107), Battelle, Pacific Northwest Division, Richland, Washington, 2000.

BNFL-RPT-028 Rev 0, Analysis of Spent Ion Exchange Media: SuperLig ${ }^{\circledR} 639$ and SuperLig ${ }^{\circledR}$ 644, Battelle, Pacific Northwest Division, Richland, Washington, 2000.

CONF-9505101--1, Batch Test Equilibration Studies Examining the Removal of Cs, Sr, and Tc from Supernatants from ORNL Underground Tanks by Selected Ion Exchangers, Oak Ridge National Lab, Tennessee, 1995. 
RPP-RPT-50122

CONF-970148--3, Comprehensive Supernate Treatment, Oak Ridge National Laboratory, Oak Ridge, Tennessee, 1996.

DE-AC21-97MC33137--43, Separation, Concentration, and Immobilization of Technetium and Iodine from Alkaline Supernate Waste, Eichrom Industries, Inc, Darien, Illinois, 1998.

DOE Manual 435.1-1, Radioactive Waste Management Manual, United States Department of Energy, 1999.

Environmental Science \& Technology, 34, 1075-1080, Development of Novel Bifunctional Anion-Exchange Resins with Improved Selectivity for Pertechnetate sorption from Contaminated Groundwater, Oak Ridge National Laboratory, Oak Ridge, Tennessee, and University of Tennessee, Knoxville, Tennessee, 2000.

Environmental Science \& Technology, 34, 3761-3766, Development of Bifunctional AnionExchange Resins with Improved Selectivity and Sorptive Kinetics for Pertechnetate: Batch-Equilibrium Experiments, Oak Ridge National Laboratory, Oak Ridge, Tennessee, and University of Tennessee, Knoxville, Tennessee, 2000.

Industrial \& Engineering Chemistry Research, 38, 1683-1689, Flowsheet Feasibility Studies Using ABEC Resins for Removal of Pertechnetate from Nuclear Wastes, Eichrom Industries, Inc., Darien, Illinois, University of Alabama, Tuscaloosa, Alabama, and Oak Ridge National Laboratory, Oak Ridge, Tennessee, 1999.

K/TCD-1141, Removal of Technetium-99 from Simulated Oak Ridge National Laboratory Newly-Generated Liquid Low-Level Waste, ORNL Chemical Technology Division, Oak Ridge National Laboratory, Oak Ridge, Tennessee, 1995

LA-12654, Rev., Distributions of 14 Elements on 63 Absorbers from Three Simulant Solutions (Acid-Dissolved Sludge, Acidified Supernate, and Alkaline Supernate) for Hanford HLW Tank 102-SY, Los Alamos National Laboratory, Los Alamos, New Mexico, 1994.

LA-12863, Distributions of 15 Elements on 58 Absorbers from Simulated Hanford Double-shell Slurry Feed (DSSF), Los Alamos National Laboratory, Los Alamos, New Mexico, 1994.

LA-12889, Distributions of 12 Elements on 64 Absorbers from Simulated Hanford Neutralized Current Acid Waste (NCWA), Los Alamos National Laboratory, Los Alamos, New Mexico, 1994.

MSE-174, Development and Testing of a Portable Treatment Unit for Technetium-99 (Tc-99) in Groundwater at 200ZP-1 Operable Unit, MSE Technology Applications, Inc., Butte, Montana, 2008.

ORNL/TM-13593, A Field Trial of Novel Bifunctional Resins for Removing Pertechetate (TcO $\left.{ }_{4}^{-}\right)$ from Contaminated Groundwater, Oak Ridge National Laboratory, Lockheed Martin Energy research Corporation, Oak Ridge, Tennessee, 1998.

ORP-11242, Rev. 5, River Protection Project System Plan, Washington River Protection Solutions, Richland, Washington, 2010.

PNL-10750, Efficient Separations and Processing Crosscutting Program: Develop and Test Sorbents, Pacific Northwest Laboratory, Richland, Washington, 1995. 
PNNL-11386, Technetium in Alkaline, High-Salt, Radioactive Tank Waste Supernate: Preliminary Characterization and Removal, Pacific Northwest National Laboratory, Richland, Washington, November 1997.

PNNL-11398, Technetium Removal Column Flow Testing with Alkaline, High Salt, Radioactive Tank Waste, Pacific Northwest National Laboratory, Richland, Washington, November 1997.

PNNL-14208, Selection and Testing of "Getters" for Adsorption of Iodine-129 and Technetium99: A Review, Pacific Northwest National Laboratory, Richland, WA, 2003.

PNNL-19681, Tc-99 Ion Exchange Resin Testing, Pacific Northwest Laboratory, Pacific Northwest National Laboratory, Richland, Washington, 2010.

RPP-RPT-23199, Rev 0, The Removal of Technetium-99 from the Effluent Treatment Facility Basin 44 Waste Using Purolite A-530E, Reillex HPQ, and Sybron IONAC SR-7 Ion Exchange Resins, CH2M Hill Hanford Company, Richland, Washington, 2004.

RPP-RPT-34697, Rev 0, Electrochemical Corrosion Report for Tanks 241-AW-103, 241-AZ102, 241-AN-106, 241-AN-107, 241-AY-101, and 241-AY-102, CH2M HILL Hanford Group, Inc., Richland, Washington, 2007.

RPP-RPT-38319, Rev 0, Electrochemical Corrosion Tests for Tank 241-AP-105 Supernate Using Grab Samples 5AP-07-01, \%AP-07-02A, 5AP-07-03A, and 5AP-07-04A, CH2MHILL Hanford Group, Inc., Richland, Washington, 2008.

RPP-RPT-39195, Rev. 1, Assessment of Technetium Leachability in Cement-Stabilized Basin 43 Groundwater Brine, Washington River Protection Solutions, Richland, Washington, 2009.

RR196, New Technologies for Metal Ion Separations: Aqueous Biphasic Extraction Chromatography (ABEC). Part I. Uptake of Pertechnetate, Department of Chemistry, Northern Illinois University, DeKalb, Illinois, Argonne National Laboratory, Argonne, Illinois, 1996.

SGW-46453, Rev 0, Testing Guidelines for Technetium99 Adsorption on Activated Carbon, CH2MHILL Plateau Remediation Company, Richland, Washington, 2010.

SRTC-BNFL-013 Rev 0, Evaluation of the Radiation Stability of SuperLig ${ }^{\circledR}$ 639, Westinghouse Savannah River Company, Aiken, South Carolina, 1997.

SFV-2000, FeedVectorWTP Realignment AOff BEL Gen-6.l-8.40-2010-O-07-at-15-14-1ll.xlsx., Washington River Protection Solutions, Richland, Washington, 2010.

SVF-2023, Immobilization System Hazard Category Source Term for Pre-Conceptual Candidate Technologies, Washington River Protection Solutions, Richland, Washington, 2011.

WHC-SD-WM-TI-699, Rev. 1, Technical Basis for Classification of Low-Activity Waste Fraction from Hanford Site Tanks, Westinghouse Hanford Company, Richland, Washington, 1996.

WHC-SD-WM-TI-718, Technetium Removal: Preliminary Flowsheet Options, Westinghouse Hanford Company, Richland, Washington, 1995. 
WSRC-MS-2000-00499, Comprehensive Scale Testing of the Ion Exchange Removal of Cesium and Technetium from Hanford Tank Wastes, CH2MHill Hanford Group, Richland, Washington, 2000.

WSRC-MS-2001-00573, SuperLig ${ }^{\circledR} 639$ Equilibrium Sorption data for Technetium from Hanford Tank Waste Supernates, Westinghouse Savannah River Company, Aiken, South Carolina, 2001.

WSRC-MS-2001-00760, Technetium Removal from Hanford and Savannah River Site Actual Tank Waste Supernates with SuperLig 639 Resin, Westinghouse Savannah River Co., Aiken, South Carolina, 2001.

WSRC-MS-2003-00789, Multiple Ion Exchange Column Tests for Technetium Removal from Hanford Tank Waste Supernate (U), Westinghouse Savannah River Company, Aiken South Carolina, 2003.

WSRC-MS-2003-00792, Column Performance Testing of SuperLig ${ }^{\circledR} 639$ Resin with Simulated Hanford Waste Supernates: Identification of the Primary Sorbing Species and Detailed Characterization of Their Desorption Profiles, Savannah River Technology Center, Westinghouse Savannah River Company, Aiken, South Carolina, 2003.

WSRC-MS-98-00601, Pretreatment/Radionuclide Separations of Cs/Tc from Supernates, Westinghouse Savannah River Company, Aiken, South Carolina, 1998.

WSRC-TR-2000-00302, Summary of Testing of SuperLig ${ }^{\circledR} 639$ at the TFL Ion Exchange Facility, Savannah River Technology Center, Westinghouse Savannah River Company, Aiken, South Carolina, 2000.

WSRC-TR-2000-00303, Rev 0, Demonstration of an Ion Exchange Resin Addition/Removal System with SuperLig® 659, Westinghouse Savannah River Company, Aiken, South Carolina, 2000.

WSRC-TR-2000-00305, Preliminary Ion Exchange Modeling for Removal of Technetium from Hanford Waste Using SuperLig ${ }^{\circledR} 639$ Resin, Westinghouse Savannah River Company, Aiken, South Carolina, 2000.

WSRC-TR-2000-00419, Rev 0, Small-Scale Ion Exchange removal of Cesium and Technetium form Envelope B Hanford Tank 241-AZ-102, Westinghouse Savannah River Company, Aiken, South Carolina, 2001.

WSRC-TR-2000-00420, Intermediate-Scale Ion Exchange Removal of Cesium and Technetium from Hanford Tank 241-AN-102, Westinghouse Savannah River Company, Aiken, South Carolina, 2000.

WSRC-TR-2000-00424, Rev 0, Tank 241-AZ-102 SuperLig® 639 Technetium Ion Exchange Eluate Evaporation Study, Westinghouse Savannah River Company, Aiken, South Carolina, 2000.

WSRC-TR-2002-00495, Rev 0, Evaluating the Effects of Tri-Butyl Phosphate (TBP) and Normal Paraffin Hydrocarbon (NPH) in Simulated Low-Activity Waste Solution on Ion Exchange, Savannah River Technology Center, Westinghouse Savannah River Company, Aiken, South Carolina, 2002. 
WSRC-TR-2003-00098, Rev 1, Multiple Ion Exchange Column Runs for Cesium and Technetium Removal from AW-101 Waste Sample (U), Savannah River National Laboratory, Westinghouse Savannah River Company, Aiken, South Carolina, 2004.

WSRC-TR-99-00317, Qualification of Reillex ${ }^{\mathrm{TM}} H P Q$ Anion Exchange Resin for Use in SRS Processes, William J, Crooks III, et. Al., Westinghouse Savannah River Company, Aiken, SC, 2000.

WTP-RPT-024, Rev 0, Radiation Stability Testing of SuperLig $(639$ and SuperLig $(644$ Resins, Battelle, Pacific Northwest Division, Richland, Washington, 2003.

WTP-RPT-030, Rev 0, Small Column Testing of SuperLig ${ }^{\circledR} 639$ for Removing ${ }^{99}$ Tc from Hanford Tank Waste Envelope A (Tank 241-AP-101), Battelle, Pacific Northwest Division, Richland, Washington, 2002.

WTP-RPT-031, Rev 1, Small Column Testing of SuperLig 639 for Removing 99Tc from Hanford Tank Waste 241-AN-102 Supernate (Envelope C) Mixed with Tank 241-C-104 Solids (Envelope D) Wash and Permeate Solutions, Battelle, Pacific Northwest Division, Richland, Washington, 2004.

WTP-RPT-047, Rev 0, Chemical Degradation of SuperLig ${ }^{\circledR} 639$ Ion Exchange Resin, Battelle, Pacific Northwest Division, Richland, Washington, 2003.

WTP-RPT-058, Rev 1, Small Column Testing of SuperLig ${ }^{\circledR} 639$ for Removing 99Tc from Hanford Tank Waste Envelope B (Tank 241-AZ-101), Battelle, Pacific Northwest Division, Richland, Washington, 2004. 
RPP-RPT-50122

\section{GLOSSARY OF TERMS}

ACIDITY: An expression of the concentration of hydrogen ions present in a solution.

ABSORPTION: The incorporation of a substance in one state into another of a different state (e.g., liquids being absorbed by a solid or gases being absorbed by a liquid).

ADSORBENT: A synthetic resin possessing the ability to attract and hold charged particles.

ADSORPTION: The attachment of charged particles to the chemically active groups on the surface and in the pores of an ion exchanger.

ALKALINITY: An expression of the total basic anions (hydroxyl groups) present in a solution. It also represents, particularly in water analysis, the bicarbonate, carbonate and occasionally the borate, silicate and phosphate salts which will react with water to produce the hydroxyl groups.

ANION: A negatively charged ion.

ANION INTERCHANGE: The displacement of one negatively charged particle by another on an anion exchange material

ASH: The residual mineral content of resin after incineration at $800^{\circ} \mathrm{C}$.

ATTRITION: The rubbing of one particle against another in a resin bed; frictional wear that will affect the size of resin particles.

BACKWASH: The upward flow of water through a resin bed (i.e., in at the bottom of the exchange unit, out at the top) to clean and reclassify the bed after exhaustion.

BASE: The hydroxyl form of a cation or a compound that can neutralize an acid.

BASE-EXCHANGE: The property of the trading of cations shown by certain insoluble naturally occurring materials (zeolites) and developed to a high degree of specificity and efficiency in synthetic resin adsorbents.

BATCH OPERATION: The utilization of ion exchange resins to treat a solution in a container wherein the removal of ions is accomplished by agitation of the solution and subsequent decanting of the treated liquid.

BED: The ion exchange resin contained in a column.

BED DEPTH: The height of the resinous material in the column after the exchanger has been properly conditioned for effective operation.

BED EXPANSION: The effect produced during backwashing: The resin particles become separated and rise in the column. The expansion of the bed due to the increase in the space between resin particles may be controlled by regulating backwash flow.

BREAKTHROUGH: The first appearance in the solution flowing from an ion exchange unit of unadsorbed ions similar to those which are depleting the activity of the resin bed. Breakthrough is an indication that regeneration of the resin is necessary.

BRINE: A salt solution, generally sodium chloride, in a saturated solution.

CAPACITY: The ability of an ion exchange material to absorb ions; usually expressed in kilograins per cubic foot or milliequivalents per milliliter. 
CATION: A positively charged ion.

CHANNELING: Cleavage and furrowing of the bed due to faulty operational procedures, in which the solution being treated follows the path of least resistance, runs through these furrows, and fails to contact active groups in other parts of the bed.

CHEMICAL STABILITY: Resistance to chemical change that ion exchange resins must possess despite contact with aggressive solutions.

COLLOIDAL: Composed of extremely small size particles that are not removed by normal filtration.

COLOR-THROW: Discoloration of the liquid passing through an ion exchange material; the flushing from the resin interstices of traces of colored organic reaction intermediates.

COLUMN OPERATION: Conventional utilization of ion exchange resins in columns through which pass, either up-flow or down-flow, the solution to be treated.

CROSSLINKAGE: The degree of binding of a monomer or set of monomers to form an insoluble tri-dimensional resin matrix.

CYCLE: A complete course of ion exchange operation. For instance, a complete cycle of cation exchange would involve exhaustion of regenerated bed, backwash, regeneration and rinse to remove excess regenerant.

DEIONIZATION: A more general term than deashing, deionization includes the removal of all charged constituents or ionizable salts (both inorganic and organic) from solution.

DENSITY: The weight of a given volume of exchange material, backwashed and in place in the column.

DIFFUSION: The diffusion of ions through the ion exchange resin beads.

DISSOCIATE: The process of ionization of an electrolyte or a salt upon being dissolved in water, forming ions of cation and anion.

DOWN-FLOW: Conventional direction of solutions to be processed in ion exchange column operation, i.e., in at the top, out at the bottom of the column.

DRY SOLIDS: The matter, usually expressed in weight percent, remaining after liquid removal.

EFFICIENCY: The effectiveness of the operational performance of an ion exchanger.

Efficiency in the adsorption of ions is expressed as the quantity of regenerant required to remove a specified unit weight of adsorbed material.

EFFLUENT: The solution that emerges from an ion exchange column.

ELECTROLYTE: A chemical compound that dissociates or ionizes in water to produce a solution the will conduct an electric current -- an acid, base or salt.

ELUTION: The stripping of adsorbed ions from an ion exchange material by the use of solutions containing other ions in relatively high concentrations.

EQUIVALENT WEIGHT: The molecular weight of any element or radical expressed as grams, pounds, etc., divided by the valence.

EXCHANGE SITES: The reactive groups on an ion exchange resin. 
EXHAUSTION: The state in which the resin is no longer capable of useful ion exchange; the depletion of the exchanger's supply of available ions. The exhaustion point is determined arbitrarily in terms of: (a) a value in parts per million of ions in the effluent solution; and/or (b) the reduction in quality of the effluent water determined by a conductivity bridge which measures the electrical resistance of the water.

FLOW RATE: The volume of solution passing through a given quantity of resin within a given time. It is usually expressed in terms of gallons per minute per cubic foot of resin, as milliliters per minute per milliliter of resin or as gallons per square foot of resin per minute.

FREEBOARD: The space provided above the resin bed in an ion exchange column to allow for expansion of the bed during backwashing.

GEL: Ion exchange resins that are made up of firm gel structure in a solid bead form allowing for the diffusion of ions through the gel.

HEADLOSS: The reduction in liquid pressure associated with the passage of a solution through a bed of exchange material; a measure of the resistance of a resin bed to the flow of the liquid passing through it.

HYDRAULIC CLASSIFICATION: The rearrangement of resin particles in an ion exchange unit. As the backwash water flows up through the resin bed, the particles become mobile. The larger particles settle and the smaller particles rise to the top of the bed.

HYDROXYL: The term used to describe the anionic radical (OH-), which is responsible for the alkalinity of a solution.

INFLUENT: The solution that enters an ion exchange unit.

ION: Any particle of less than colloidal size possessing either a positive or a negative electric charge.

IONIZATION: The dissociation of molecules into charged particles.

LEAKAGE: The phenomenon in which some of the influent ions are not adsorbed or exchanged and appear in the effluent when a solution is passed through an under- regenerated exchange resin bed.

MACROPOROUS: Resins that have a rigid polymer porous network in which there exists a true pore structure even after drying. The pores are larger than atomic distances and are not part of the gel structure.

MONOMER: A single reactive molecule capable of combining with another different monomer to form a polymer.

$\mathrm{pH}$ : The measurement of the acidity of a solution where 1 is very acidic, 7 is neutral and 14 is very basic.

PHYSICAL STABILITY: The quality that an ion exchange resin must possess to resist changes that might be caused by attrition, high temperatures and other physical conditions.

POROSITY: An expression of the degree of permeability in ion exchange resins to liquids and large organic molecules. Gel resins, even when referred to as highly porous, have a negligible porosity in comparison to the macropores inherent in the macroporous resins. 
POSITIVE CHARGE: The electrical potential acquired by an atom that has lost one or more electrons; a characteristic of a cation.

QUATERNARY AMMONIUM: A specific basic group [-N(CH3)3+] on which depends the exchange activity of certain anion exchange resins.

RAW WATER: Untreated water from wells or from surface sources.

REGENERANT: The solution used to restore the activity of an ion exchanger. Acids are employed to restore a cation exchanger to its hydrogen form, while brine solutions may be used to convert the cation exchanger to the sodium form. The anion exchanger may be rejuvenated by treatment with an alkaline solution.

REGENERATION: Restoration of the activity of an ion exchanger by replacing the ions adsorbed from the treated solution by ions that were adsorbed initially on the resin.

RESIN: An insoluble matrix (or support structure) normally in the form of small (1-2 mm diameter) beads, fabricated from an organic polymer substrate. The material has highly developed structure of pores on the surface, which are sites with easily trapped and released ions.

RINSE: The operation that follows regeneration; a flushing out of excess regenerant solution.

SALT SPLITTING: The conversion of salts to their corresponding acids or bases by passage through ion exchange resins containing strongly acidic or strongly basic functional groups.

SELECTIVITY: The difference in attraction of one ion over another by an ion exchange resin.

SORPTION: Refers to the action of absorption or adsorption. Absorption is the incorporation of a substance in one state into another of a different state (e.g., liquids being absorbed by a solid or gases being absorbed by a liquid). Adsorption is the physical adherence or bonding of ions and molecules onto the surface of another phase (e.g., reagents adsorbed to solid catalyst surface).

SWELLING: The expansion of an ion exchange bed that occurs when the reactive groups on the resin are converted into certain forms.

THROUGHPUT: The amount of solution treated prior to the exhaustion of the ion exchange resin.

UP-FLOW: The operation of an ion exchange unit in which solutions are passed in at the bottom and out at the top of the container.

VALANCE: A measurement of the number of atoms or ions of hydrogen it takes to combine with, or be replaced by, an element or radical. In short, it is the number of positive or negative charges of an ion.

VOID VOLUME: The space between particles of ion exchange resins in a settled bed, also called interstitial volume.

WEAK ELECTROLYTE: The equivalent of weakly acidic or weakly basic resins not capable of splitting neutral salts.

ZEOLITE: A mineral composed of hydrated silicates of aluminum and sodium or calcium. The term has been used, sometimes improperly, to describe softening done by synthetic ion exchange resins. 


\section{APPENDIX A SORPTION MEDIA REFERENCE MATRIX}

Table A-6-1. Sorption Media References by Feed Solution

\begin{tabular}{|c|c|c|c|c|c|c|c|c|}
\hline $\begin{array}{l}\text { Ion Exchange / Sorbent } \\
\text { Media }\end{array}$ & Disposition & References & $\begin{array}{l}\text { Hanford } \\
\text { Tank } \\
\text { Waste }\end{array}$ & $\begin{array}{c}\text { Hanford Tank } \\
\text { waste } \\
\text { simulant } \\
\text { spiked with } \\
\text { Tc }\end{array} \mid$ & $\begin{array}{c}\text { Hanford tank } \\
\text { waste simulant } \\
\text { with } \operatorname{Re}(\text { as a } \\
\text { surrogate for Tc) }\end{array}$ & $\begin{array}{c}\text { DOE Radioactive } \\
\text { tank waste from } \\
\text { another site }\end{array}$ & Other & Comments \\
\hline Duolite ${ }^{\mathrm{TM}}{ }^{12}$ CS-100 & $\begin{array}{l}\text { Not Selected } \\
\text { for Review } \\
\text { (SME) }\end{array}$ & $\begin{array}{l}\text { LA-12654, Rev., Distributions of } 14 \text { Elements on } 63 \text { Absorbers } \\
\text { from Three Simulant Solutions (Acid-Dissolved Sludge, Acidified } \\
\text { Supernate, and Alkaline Supernate) for Hanford HLW Tank 102-SY }\end{array}$ & & $\mathrm{x}$ & & & & \\
\hline \multirow[t]{2}{*}{ ABEC 2000} & \multirow[t]{2}{*}{$\begin{array}{l}\text { Selected for } \\
\text { Review }\end{array}$} & $\begin{array}{l}\text { RR } 196 \text { New Technologies for Metal Ion Separations: Aqueous } \\
\text { Biphasic Extraction Chromatography (ABEC). Part I. Uptake of } \\
\text { Pertechnetate }\end{array}$ & & $\mathrm{x}$ & & & $\mathrm{x}$ & \\
\hline & & $\begin{array}{l}\text { DE-AC21-97MC33137 Separation, Concentration, and } \\
\text { Immobilization of Technetium and Iodine from Alkaline Supernate } \\
\text { Waste }\end{array}$ & X & $\mathrm{x}$ & & $\mathrm{x}$ & $\mathrm{x}$ & $\begin{array}{l}\text { These waste streams include actual Hanford tank waste from tank AW-101, (a } \\
\text { cesium decontaminated double shell slurry feed composite), three different } \\
\text { Hanford tank waste simulants, actual waste samples from ORNL Melton } \\
\text { Valley Storage Tanks W-29 and W-3, and waste simulant solutions from two } \\
\text { British Nuclear Fuel (BNFL) locations-Capenhurst and Sellafield-in the } \\
\text { United Kingdom. }\end{array}$ \\
\hline \multirow[t]{4}{*}{$\begin{array}{l}\text { Aliquat } \\
\text { (tricaprylmethylammonium } \\
\text { chloride) }\end{array}$} & \multirow[t]{4}{*}{$\begin{array}{l}\text { Not Selected } \\
\text { for Review } \\
\text { (WTP } \\
\text { Screening) }\end{array}$} & $\begin{array}{l}\text { LA-12654, Rev., Distributions of } 14 \text { Elements on } 63 \text { Absorbers } \\
\text { from Three Simulant Solutions (Acid-Dissolved Sludge, Acidified } \\
\text { Supernate, and Alkaline Supernate) for Hanford HLW Tank } 102-S Y\end{array}$ & & $\mathrm{x}$ & & & & \\
\hline & & $\begin{array}{l}\text { LA-12863, Distributions of } 15 \text { Elements on } 58 \text { Absorbers from } \\
\text { Simulated Hanford Double-shell Slurry Feed (DSSF) }\end{array}$ & & $\mathrm{x}$ & & & & \\
\hline & & $\begin{array}{l}\text { LA-12889, Distributions of } 12 \text { Elements on } 64 \text { Absorbers from } \\
\text { Simulated Hanford Neutralized Current Acid Waste (NCAW) }\end{array}$ & & $\mathrm{x}$ & & & & \\
\hline & & $\begin{array}{l}\text { PNL-10750 Efficient Separations and Processing Crosscutting } \\
\text { Program: Develop and Test Sorbents }\end{array}$ & & & & & $\mathrm{x}$ & \\
\hline Amberlite ${ }^{\mathrm{TM}}{ }^{14} \mathrm{IRA}-400$ & $\begin{array}{l}\text { Not Selected } \\
\text { for Review } \\
\text { (SEM) }\end{array}$ & $\begin{array}{l}\text { CONF-9505101-1 Batch Test Equilibration Studies Examining the } \\
\text { Removal of Cs, Sr, and Tc from Supernatants from ORNL } \\
\text { Underground Tanks by Selected Ion Exchangers }\end{array}$ & & & & $\mathrm{x}$ & & \\
\hline
\end{tabular}

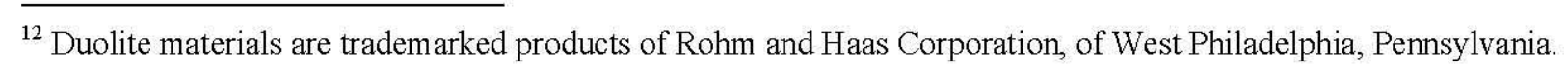

${ }^{13}$ Original product registrant was General Mills, of Minneapolis, Minnesota. Current registrant is Cognis IP Management GmbH Corporation of Duesseldorf, Germany.

${ }^{14}$ Amberlite products are trademarked by Rohm \& Haas Corporation, of West Philadelphia, Pennsylvania. 
RPP-RPT-50122

Appendix A - Sorption Media Reference Matrix

\begin{tabular}{|c|c|c|c|c|c|c|c|c|}
\hline $\begin{array}{l}\text { Ion Exchange / Sorbent } \\
\text { Media }\end{array}$ & Disposition & References & $\begin{array}{l}\text { Hanford } \\
\text { Tank } \\
\text { Waste }\end{array}$ & $\begin{array}{c}\text { Hanford Tank } \\
\text { waste } \\
\text { simulant } \\
\text { spiked with } \\
\text { Tc }\end{array}$ & $\begin{array}{c}\text { Hanford tank } \\
\text { waste simulant } \\
\text { with } \operatorname{Re} \text { (as a } \\
\text { surrogate for Tc) }\end{array}$ & $\begin{array}{l}\text { DOE Radioactive } \\
\text { tank waste from } \\
\text { another site }\end{array}$ & Dther & Comments \\
\hline Amberlite IRA-904 & $\begin{array}{l}\text { Not Selected } \\
\text { for Review } \\
\text { (SME) }\end{array}$ & $\begin{array}{l}\text { CONF-9505101-1 Batch Test Equilibration Studies Examining the } \\
\text { Removal of Cs, Sr, and Tc from Supernatants from ORNL } \\
\text { Underground Tanks by Selected Ion Exchangers }\end{array}$ & & & & $\mathrm{x}$ & & \\
\hline Amberlite XE-238 & $\begin{array}{l}\text { Not Selected } \\
\text { for Review } \\
\text { (WTP } \\
\text { Screening) }\end{array}$ & & & & & & & \\
\hline Azaphosphane-based resins & $\begin{array}{l}\text { Not Selected } \\
\text { for Review } \\
\text { (WTP } \\
\text { Screening) }\end{array}$ & & & & & & & \\
\hline Bio-Rad" ${ }^{T M^{15}}$ AG 1-x8 & $\begin{array}{l}\text { Not Selected } \\
\text { for Review } \\
\text { (SME) }\end{array}$ & $\begin{array}{l}\text { K/TCD-1141 Removal of Technetium-99 from Simulated Oak } \\
\text { Ridge National Laboratory Newly-Generated Liquid Low-Level } \\
\text { Waste }\end{array}$ & & & & & & $\begin{array}{l}\text { Simulated Oak Ridge National Lab Newly Generaged Liquid Low-Level } \\
\text { Waste }\end{array}$ \\
\hline Bio-Rad MSZ-1 & $\begin{array}{l}\text { Not Selected } \\
\text { for Review } \\
\text { (WTP } \\
\text { Screening) }\end{array}$ & & & & & & & \\
\hline BiQuat ${ }^{16}$ RO-02-119 & $\begin{array}{l}\text { Not Selected } \\
\text { for Review } \\
\text { (WTP } \\
\text { Screening) }\end{array}$ & & & & & & & \\
\hline BiQuat VP-02-217 & $\begin{array}{l}\text { Not Selected } \\
\text { for Review } \\
\text { (WTP } \\
\text { Screening) }\end{array}$ & & & & & & & \\
\hline
\end{tabular}

\footnotetext{
${ }^{15}$ Bio-Rad products are trademarked by Bio-Rad Laboratories of Hercules, California.
}

${ }^{16}$ BiQuat materials are formulated by Oak Ridge National Laboratory in conjunction with the University of Tennessee. 
RPP-RPT-50122

Appendix A - Sorption Media Reference Matrix

\begin{tabular}{|c|c|c|c|c|c|c|c|c|}
\hline $\begin{array}{l}\text { Ion Exchange / Sorbent } \\
\text { Media }\end{array}$ & Disposition & References & $\begin{array}{l}\text { Hanford } \\
\text { Tank } \\
\text { Waste }\end{array}$ & $\begin{array}{l}\text { Hanford Tank } \\
\text { waste } \\
\text { simulant } \\
\text { spiked with } \\
\text { Tc }\end{array}$ & $\begin{array}{c}\text { Hanford tank } \\
\text { waste simulant } \\
\text { with } \operatorname{Re}(\text { as a } \\
\text { surrogate for Tc) }\end{array}$ & $\begin{array}{c}\text { DOE Radioactive } \\
\text { tank waste from } \\
\text { another site }\end{array}$ & Other & Comments \\
\hline $\begin{array}{l}\text { Boehmite, Synthetic aluminun } \\
\text { oxyhydroxide gel }\end{array}$ & $\begin{array}{l}\text { Not Selected } \\
\text { for Review } \\
\text { (WTP } \\
\text { Screening) }\end{array}$ & & & & & & & \\
\hline \multirow[t]{6}{*}{ ABEC 5000} & $\begin{array}{l}\text { Selected for } \\
\text { Review }\end{array}$ & $\begin{array}{l}\text { PNNL-13386 Technetium in Alkaline, High-Salt, Radioactive Tank } \\
\text { Waste Supernate: Preliminary Characterization and Removal }\end{array}$ & $\mathrm{x}$ & & & & & DSSF and 3 CC wastes (AN-107, SY-101, ANS SY-103) \\
\hline & & $\begin{array}{l}\text { RR 196, New Technologies for Metal Ion Separations: Aqueous } \\
\text { Biphasic Extraction Chromatography (ABEC). Part I. Uptake of } \\
\text { Pertechnetate }\end{array}$ & $\mathrm{x}$ & & & & $\mathrm{x}$ & \\
\hline & & $\begin{array}{l}\text { DE-AC21-97MC33137, Separation, Concentration, and } \\
\text { Immobilization of Technetium and Iodine from Alkaline Supernate } \\
\text { Waste }\end{array}$ & $\mathrm{x}$ & $\mathrm{x}$ & & $\mathrm{x}$ & $\mathrm{x}$ & $\begin{array}{l}\text { These waste streams include actual Hanford tank waste from tank AW-101, (a } \\
\text { cesium decontaminated double shell slurry feed composite), three different } \\
\text { Hanford tank waste simulants, actual waste samples from ORNL Melton } \\
\text { Valley Storage Tanks W-29 and W-3, and waste simulant solutions from two } \\
\text { Bititish Nuclear Fuel (BNFL) locations - Capenhurst and Sellafield-in the } \\
\text { United Kingdom. }\end{array}$ \\
\hline & & $\begin{array}{l}\text { PNNL-11398, Technetium Removal Column Flow Testing with } \\
\text { Alkaline, High Salt, Radioactive Tank Waste }\end{array}$ & $\mathrm{x}$ & & & & & DSSF/ AW-101 \\
\hline & & $\begin{array}{l}\text { WSRC-MS-98-00601, PretreatmentRadionuclide Separations of } \\
\text { CS/TC from Supernates }\end{array}$ & & & & $\mathrm{x}$ & & ORNL wastes \\
\hline & & CONF-970148-3, Comprehensive Supernate Treatment & & & & & $\mathrm{x}$ & $\begin{array}{l}\text { MVST W- } 29 \text { supernate depleted in cesium and strontium and spiked with } \\
\text { pertechnetate. }\end{array}$ \\
\hline Activated Carbon & $\begin{array}{l}\text { Not Selected } \\
\text { for Review } \\
\text { (WTP } \\
\text { Screening) }\end{array}$ & $\begin{array}{l}\text { SGW-46453, Testing Guidelines for Technetium } 99 \text { Adsorption on } \\
\text { Activated Carbon }\end{array}$ & & & & & $\mathrm{x}$ & \\
\hline $\begin{array}{l}\text { Cross-linked Polyvinyl } \\
\text { Pyridine }\end{array}$ & $\begin{array}{l}\text { Not Selected } \\
\text { for Review } \\
\text { (WTP } \\
\text { Screening) }\end{array}$ & & & & & & & \\
\hline
\end{tabular}


RPP-RPT-50122

Appendix A - Sorption Media Reference Matrix

\begin{tabular}{|c|c|c|c|c|c|c|c|c|}
\hline $\begin{array}{l}\text { Ion Exchange / Sorbent } \\
\text { Media }\end{array}$ & Disposition & References & $\begin{array}{l}\text { Hanford } \\
\text { Tank } \\
\text { Waste }\end{array}$ & $\begin{array}{l}\text { Hanford Tank } \\
\text { waste } \\
\text { simulant } \\
\text { spiked with } \\
\text { Tc }\end{array}$ & $\begin{array}{c}\text { Hanford tank } \\
\text { waste simulant } \\
\text { with } \operatorname{Re}(\text { as a } \\
\text { surrogate for Tc) }\end{array}$ & $\begin{array}{c}\text { DOE Radioactive } \\
\text { tank waste from } \\
\text { another site }\end{array}$ & Other & Comments \\
\hline Crypt-DER ${ }^{17}$ & $\begin{array}{l}\text { Not Selected } \\
\text { for Review } \\
\text { (WTP } \\
\text { Screening) }\end{array}$ & & & & & & & \\
\hline Dowex 1X8 & $\begin{array}{l}\text { Selected for } \\
\text { Review }\end{array}$ & $\begin{array}{l}\text { K/TCD-1141, Removal of Technetium-99 from Simulated Oak } \\
\text { Ridge National Laboratory Newly-Generated Liquid Low-Level } \\
\text { Waste }\end{array}$ & & & & $\mathrm{x}$ & & $\begin{array}{l}\text { Simulated Oak Ridge National Lab Newly Generaged Liquid Low-Level } \\
\text { Waste }\end{array}$ \\
\hline Dowex 2X8 & $\begin{array}{l}\text { Not Selected } \\
\text { for Review } \\
\text { (WTP } \\
\text { Screening) }\end{array}$ & $\begin{array}{l}\text { K/TCD-1141, Removal of Technetium-99 from Simulated Oak } \\
\text { Ridge National Laboratory Newly-Generated Liquid Low-Level } \\
\text { Waste }\end{array}$ & & & & $\mathrm{x}$ & & $\begin{array}{l}\text { Simulated Oak Ridge National Lab Newly Generaged Liquid Low-Level } \\
\text { Waste }\end{array}$ \\
\hline Forager ${ }^{\mathrm{TM}^{18}}$ Sponge & $\begin{array}{l}\text { Not Selected } \\
\text { for Review } \\
\text { (WTP } \\
\text { Screening) }\end{array}$ & & & & & & & \\
\hline IONSIVTM $^{19}$ IE-910 & $\begin{array}{l}\text { Not Selected } \\
\text { for Review } \\
\text { (SME) }\end{array}$ & & & & & & & \\
\hline Iron Sulfide & $\begin{array}{l}\text { Not Selected } \\
\text { for Review } \\
\text { (WTP } \\
\text { Screening) }\end{array}$ & & & & & & & \\
\hline LANL $^{20}$ - TiO2/carbon beads & $\begin{array}{l}\text { Not Selected } \\
\text { for Review } \\
\text { (WTP } \\
\text { Screening) }\end{array}$ & $\begin{array}{l}\text { LA-12654, Rev., Distributions of } 14 \text { Elements on } 63 \text { Absorbers } \\
\text { from Three Simulant Solutions (Acid-Dissolved Sludge, Acidified } \\
\text { Supernate, and Alkaline Supernate) for Hanford HLW Tank 102-SY }\end{array}$ & & $\mathrm{x}$ & & & & \\
\hline
\end{tabular}

\footnotetext{
${ }^{17}$ No trademarks or proprietary information located.

${ }^{18}$ Forager sponges and other Forager products are manufactured by Dynaphore, Inc., of Richmond, Virginia.

${ }^{19}$ ION-SIV products are trademarked by the Union Carbide Corporation, of New York, New York.

${ }^{20}$ Formulated at the Los Alamos National Laboratory.
} 
RPP-RPT-50122

Appendix A - Sorption Media Reference Matrix

\begin{tabular}{|c|c|c|c|c|c|c|c|c|}
\hline $\begin{array}{c}\text { Ion Exchange / Sorbent } \\
\text { Media }\end{array}$ & Disposition & References & $\begin{array}{l}\text { Hanford } \\
\text { Tank } \\
\text { Waste }\end{array}$ & $\begin{array}{l}\text { Hanford Tank } \\
\text { waste } \\
\text { simulant } \\
\text { spiked with } \\
\text { Tc }\end{array}$ & $\begin{array}{c}\text { Hanford tank } \\
\text { waste simulant } \\
\text { with } \operatorname{Re}(\text { as a } \\
\text { surrogate for Tc) }\end{array}$ & $\begin{array}{c}\text { DOE Radioactive } \\
\text { tank waste from } \\
\text { another site }\end{array}$ & Other & Comments \\
\hline \multirow[t]{4}{*}{ Purolite A-520E } & \multirow[t]{4}{*}{$\begin{array}{l}\text { Selected for } \\
\text { Review }\end{array}$} & $\begin{array}{l}\text { LA-12654, Rev., Distributions of } 14 \text { Elements on } 63 \text { Absorbers } \\
\text { from Three Simulant Solutions (Acid-Dissolved Sludge, Acidified } \\
\text { Supernate, and Alkaline Supernate) for Hanford HLW Tank } 102-S Y\end{array}$ & & $\mathrm{x}$ & & & & \\
\hline & & $\begin{array}{l}\text { LA-12863, Distributions of } 15 \text { Elements on } 58 \text { Absorbers from } \\
\text { Simulated Hanford Double-shell Shurry Feed (DSSF), Los Alamos } \\
\text { National Laboratory, Los Alamos, New Mexico, } 1994 \text {. }\end{array}$ & & $\mathrm{x}$ & & & & \\
\hline & & $\begin{array}{l}\text { LA-12889, Distributions of } 12 \text { Elements on } 64 \text { Absorbers from } \\
\text { Simulated Hanford Neutralized Current Acid Waste (NCWA), Los } \\
\text { Alamos National Laboratory, Los Alamos, New Mexico, } 1994 .\end{array}$ & & $\mathrm{x}$ & & & & \\
\hline & & $\begin{array}{l}\text { ORNL/TM-13593, A Field Trial of Novel Bifunctinal Resins for } \\
\text { Removing Pertechnetate (TcO4-) from Contaminated Groundwater }\end{array}$ & & & & & $\mathrm{x}$ & \\
\hline \multirow[t]{6}{*}{ Purolite A-530E } & \multirow[t]{6}{*}{$\begin{array}{l}\text { Selected for } \\
\text { Review }\end{array}$} & RPP-RPT-39195 Rev. 1 & & & & & $\mathrm{x}$ & $\begin{array}{l}\text { Brine solution of } 25 \mathrm{wt} \% \text { mimicking the anticipated Basin } 43 \text { waste from the } \\
\text { ETF }\end{array}$ \\
\hline & & $\begin{array}{l}\text { RPP-RPT-23199, Rev } 0 \text { The Removal of Technetium-99 from the } \\
\text { Effluent Treatment Facility Basin } 44 \text { Waste Using Purolite A-530E, } \\
\text { Reillex HPQ, and Sybron IONAC SR-7 Ion Exchange Resins }\end{array}$ & & & & & $\mathrm{x}$ & ETF Basin 44 Reverse Osmosis (RO) reject stream \\
\hline & & $\begin{array}{l}\text { MSE-174, Development and Testing of a Portable Treatment Unit } \\
\text { for Technetium-99 (Tc-99) in Groundwater at 200ZP-1 Operable } \\
\text { Unit }\end{array}$ & & & & & $\mathrm{x}$ & $\begin{array}{l}\text { Column and batch testing at the Mike Mansfield Advanced Technology Center } \\
\text { (MMATC) using the perrhenate ion as a surrogate for technetium-99 }\end{array}$ \\
\hline & & PNNL-19681, Tc-99 Ion Exchange Resin Testing & & & & & $\mathrm{x}$ & Groundwater from well 299-W15-765 \\
\hline & & $\begin{array}{l}\text { LA-12654, Rev., Distributions of } 14 \text { Elements on } 63 \text { Absorbers } \\
\text { from Three Simulant Solutions (Acid-Dissolved Sludge, Acidified } \\
\text { Supernate, and Alkaline Supernate) for Hanford HLW Tank } 102 \text {-SY }\end{array}$ & & $\mathrm{x}$ & & & & \\
\hline & & $\begin{array}{l}\text { Environmental Science \& Technology, } 2000,34,1075-1080, \\
\text { Development of Novel Bifunctional Anion-Exchange Resins with } \\
\text { Improved Selectivity for Pertechnetate sorption from Contaminated } \\
\text { Groundwater }\end{array}$ & & & & & $\mathrm{x}$ & \\
\hline Purolite A-532E & $\begin{array}{l}\text { Selected for } \\
\text { Review }\end{array}$ & RPP-RPT-39195 Rev. 1 & & & & & $\mathrm{x}$ & $\begin{array}{l}\text { Brine solution of } 25 \mathrm{wt} \% \text { mimicking the anticipated Basin } 43 \text { waste from the } \\
\text { ETF }\end{array}$ \\
\hline
\end{tabular}


RPP-RPT-50122

Appendix A - Sorption Media Reference Matrix

\begin{tabular}{|c|c|c|c|c|c|c|c|c|}
\hline $\begin{array}{l}\text { Ion Exchange / Sorbent } \\
\text { Media }\end{array}$ & Disposition & References & $\begin{array}{l}\text { Hanford } \\
\text { Tank } \\
\text { Waste }\end{array}$ & $\begin{array}{c}\text { Hanford Tank } \\
\text { waste } \\
\text { simulant } \\
\text { spiked with } \\
\text { Tc }\end{array}$ & $\begin{array}{c}\text { Hanford tank } \\
\text { waste simulant } \\
\text { with } \operatorname{Re}(\text { as a } \\
\text { surrogate for Tc) }\end{array}$ & $\begin{array}{c}\text { DOE Radioactive } \\
\text { tank waste from } \\
\text { another site }\end{array}$ & Other & Comments \\
\hline \multirow[t]{13}{*}{ Reillex-HPQ } & \multirow[t]{13}{*}{$\begin{array}{l}\text { Selected for } \\
\text { Review }\end{array}$} & $\begin{array}{l}\text { K/TCD-1141, Removal of Technetium-99 from Simulated Oak } \\
\text { Ridge National Laboratory Newly-Generated Liquid Low-Level } \\
\text { Waste }\end{array}$ & & & & $\mathrm{x}$ & & $\begin{array}{l}\text { Simulated Oak Ridge National Lab Newly Generaged Liquid Low-Level } \\
\text { Waste }\end{array}$ \\
\hline & & $\begin{array}{l}\text { RPP-RPT-23199, Rev } 0 \text { The Removal of Technetium-99 from the } \\
\text { Effluent Treatment Facility Basin } 44 \text { Waste Using Purolite } A-530 \text {, } \\
\text { Reillex HPQ, and Sybron IONAC SR-7 Ion Exchange Resins }\end{array}$ & & & & & $\mathrm{x}$ & ETF Basin 44 Reverse Osmosis (RO) reject stream \\
\hline & & $\begin{array}{l}\text { PNNL-11386, Technetium in Alkaline, High-Salt, Radioactive Tank } \\
\text { Waste Supernate: Preliminary Characterization and Removal }\end{array}$ & & & & & & DSSF and 3 CC wastes (AN-107, SY-101, ANS SY-103) \\
\hline & & $\begin{array}{l}\text { PNNNL-11398 Technetium Removal Column Flow Testing with } \\
\text { Alkaline, High Salt, Radioactive Tank Waste }\end{array}$ & $\mathrm{x}$ & & & & & DSSF/ AW-101 \\
\hline & & $\begin{array}{l}\text { CONF-9505101--1, Batch Test Equilibration Studies Examining } \\
\text { the Removal of Cs, Sr, and Tc from Supernatants from ORNL } \\
\text { Underground Tanks by Selected Ion Exchangers }\end{array}$ & & & & $\mathrm{x}$ & & \\
\hline & & $\begin{array}{l}\text { LA-12654, Rev., Distributions of } 14 \text { Elements on } 63 \text { Absorbers } \\
\text { from Three Simulant Solutions (Acid-Dissolved Sludge, Acidified } \\
\text { Supernate, and Alkaline Supernate) for Hanford HLW Tank 102-SY }\end{array}$ & & $\mathrm{x}$ & & & & \\
\hline & & $\begin{array}{l}\text { LA-12863, Distributions of } 15 \text { Elements on } 58 \text { Absorbers from } \\
\text { Simulated Hanford Double-shell Slurry Feed (DSSF) }\end{array}$ & & $\mathrm{x}$ & & & & \\
\hline & & $\begin{array}{l}\text { LA-12889, Distributions of } 12 \text { Elements on } 64 \text { Absorbers from } \\
\text { Simulated Hanford Neutralized Current Acid Waste (NCWA), }\end{array}$ & & $\mathrm{x}$ & & & & \\
\hline & & $\begin{array}{l}\text { WSRC-MS-98-00601, PretreatmentRadionuclide Separations of } \\
\text { Cs/Tc from Supernates }\end{array}$ & $\mathrm{x}$ & & & & & \\
\hline & & $\begin{array}{l}\text { WHC-SD-WM-TI-718, Technetium Removal: Preliminary } \\
\text { Flowsheet Options }\end{array}$ & $\mathrm{X}$ & & & & & \\
\hline & & CONF-970148-3, Comprehensive Supernate Treatment & & & & & $\mathrm{x}$ & $\begin{array}{l}\text { MVST W-29 supernate depleted in cesium and strontium and spiked with } \\
\text { pertechnetate. }\end{array}$ \\
\hline & & $\begin{array}{l}\text { WHC-SD-WM-TI-699, Rev. 1, Technical Basis for Classification } \\
\text { of Low-Activity Waste Fraction from Hanford Site Tanks }\end{array}$ & & $\mathrm{x}$ & & & & DSSF simulants \\
\hline & & $\begin{array}{l}\text { Environmental Science \& Technology, 2000, 34, 3761-3766, } \\
\text { Development of Bifunctional Anion-Exchange Resins with } \\
\text { Improved Selectivity and Sorptive Kinetics for Pertechnetate: }\end{array}$ & & & & & $\mathrm{x}$ & \\
\hline
\end{tabular}


RPP-RPT-50122

Appendix A - Sorption Media Reference Matrix

\begin{tabular}{|c|c|c|c|c|c|c|c|c|}
\hline $\begin{array}{l}\text { Ion Exchange / Sorbent } \\
\text { Media }\end{array}$ & Disposition & References & $\begin{array}{l}\text { Hanford } \\
\text { Tank } \\
\text { Waste }\end{array}$ & $\begin{array}{l}\text { Hanford Tank } \\
\text { waste } \\
\text { simulant } \\
\text { spiked with } \\
\text { Tc }\end{array}$ & $\begin{array}{c}\text { Hanford tank } \\
\text { waste simulant } \\
\text { with Re (as a } \\
\text { surrogate for Tc) }\end{array}$ & $\begin{array}{c}\text { DOE Radioactive } \\
\text { tank waste from } \\
\text { another site }\end{array}$ & Other & Comments \\
\hline & & Batch-Equilibrium Experiments & & & & & & \\
\hline Reillex 402 & $\begin{array}{l}\text { Not Selected } \\
\text { for Review } \\
\text { (WTP } \\
\text { Screening) }\end{array}$ & $\begin{array}{l}\text { CONF-9505101-1, Batch Test Equilibration Studies Examining } \\
\text { the Removal of CS, Sr, and Tc from Supernatants from ORNL } \\
\text { Underground Tanks by Selected Ion Exchangers }\end{array}$ & & & & $\mathrm{x}$ & & \\
\hline Reillex HP & $\begin{array}{l}\text { Not Selected } \\
\text { for Review } \\
\text { (WTP } \\
\text { Screening) }\end{array}$ & $\begin{array}{l}\text { K/TCD-1141, Removal of Technetium-99 from Simulated Oak } \\
\text { Ridge National Laboratory Newly-Generated Liquid Low-Level } \\
\text { Waste }\end{array}$ & & & & $\mathrm{x}$ & & $\begin{array}{l}\text { Simulated Oak Ridge National Lab Newly Generaged Liquid Low-Level } \\
\text { Waste }\end{array}$ \\
\hline \multirow[t]{3}{*}{$\mathrm{Sn}^{+}$apatite } & \multirow{3}{*}{$\begin{array}{l}\text { Selected for } \\
\text { Review }\end{array}$} & Vendor Questionnaire & & & ? & & & "WTP Recycle surrogate and AN-104 Surrogate" \\
\hline & & $\begin{array}{l}\text { RPP-RPT-39195 Rev. 1, Assessment of Technetium Leachability in } \\
\text { Cement-Stabilized Basin } 43 \text { Groundwater Brine }\end{array}$ & & & & & $\mathrm{x}$ & $\begin{array}{l}\text { Simulant Basin } 43 \text { waste with concentrated brine consisting of approximately } \\
25 \text { weight percent salts. }\end{array}$ \\
\hline & & $\begin{array}{l}\text { PNNL-14208, Selection and Testing of "Getters" for Adsorption of } \\
\text { Iodine-129 and Technetium-99: A Review }\end{array}$ & & & & & $\mathrm{x}$ & Groundwater matrix and concentrated sodium salt solution. \\
\hline $\mathrm{Sr}-\mathrm{SPEC}^{\mathrm{TM}}{ }^{21}$ & $\begin{array}{l}\text { Not Selected } \\
\text { for Review } \\
\text { (WTP } \\
\text { Screening) }\end{array}$ & $\begin{array}{l}\text { LA-12654, Rev., Distributions of } 14 \text { Elements on } 63 \text { Absorbers } \\
\text { from Three Simulant Solutions (Acid-Dissolved Sludge, Acidified } \\
\text { Supernate, and Alkaline Supermate) for Hanford HLW Tank 102-SY }\end{array}$ & & $\mathrm{x}$ & & & & \\
\hline Steel Wool & $\begin{array}{l}\text { Not Selected } \\
\text { for Review } \\
\text { (SME) }\end{array}$ & $\begin{array}{l}\text { K/TCD-1141, Removal of Technetium-99 from Simulated Oak } \\
\text { Ridge National Laboratory Newly-Generated Liquid Low-Level } \\
\text { Waste }\end{array}$ & & & & & $\mathrm{x}$ & $\begin{array}{l}\text { Simulated Oak Ridge National Lab Newly Generaged Liquid Low-Level } \\
\text { Waste }\end{array}$ \\
\hline \multirow[t]{2}{*}{ SuperLig 639} & \multirow[t]{2}{*}{$\begin{array}{l}\text { Selected for } \\
\text { Review }\end{array}$} & $\begin{array}{l}\text { Science and Technology, } 40: 1,383 \text { - } 394,2005 \text {, 'Column } \\
\text { Performance Testing of SuperLig® } 839 \text { Resin with Simulated } \\
\text { Hanford Waste Supermates: Identificition of the Primary Sorbing } \\
\text { Species and Detailed Characterization of Their Desorption } \\
\text { Profiles', Separation }\end{array}$ & & & $\mathrm{x}$ & & & \\
\hline & & $\begin{array}{l}\text { PNWD-3004, BNFL-RPT-016, Rev } 0 \text { Small Column Testing of } \\
\text { SuperLig } 639 \text { for Removing Tc-99 from Hanford Tank Waste } \\
\text { Envelope A (241-AW-101) }\end{array}$ & $\mathrm{x}$ & & & & & \\
\hline
\end{tabular}

${ }^{21} \mathrm{Sr}$-SPEC is a trademarked product of Eichrom Industries of Darien, Illinois. 
RPP-RPT-50122

Appendix A - Sorption Media Reference Matrix

\begin{tabular}{|c|c|c|c|c|c|c|c|c|}
\hline $\begin{array}{l}\text { Ion Exchange / Sorbent } \\
\text { Media }\end{array}$ & Disposition & References & $\begin{array}{l}\text { Hanford } \\
\text { Tank } \\
\text { Waste }\end{array}$ & $\begin{array}{l}\text { Hanford Tank } \\
\text { waste } \\
\text { simulant } \\
\text { spiked with } \\
\text { Tc }\end{array}$ & $\begin{array}{c}\text { Hanford tank } \\
\text { waste simulant } \\
\text { with Re (as a } \\
\text { surrogate for Tc) }\end{array}$ & $\begin{array}{c}\text { DOE Radioactive } \\
\text { tank waste from } \\
\text { another site }\end{array}$ & Other & Comments \\
\hline & & $\begin{array}{l}\text { PNWD-3028, BNFL-RPT-022 Rev. 0, Small Column Testing of } \\
\text { Superlig } 639 \text { for Removing Tc99 from Hanford Tank Waste } \\
\text { Envelope C (Tank 241-AN-107) }\end{array}$ & $\mathrm{X}$ & & & & & \\
\hline & & $\begin{array}{l}\text { WSRC-MS-2000-00499, Comprehensive Scale Testing of the Ion } \\
\text { Exchange Removal of Cesium and Technetium from Hanford Tank } \\
\text { Wastes }\end{array}$ & $\mathrm{x}$ & & $\mathrm{x}$ & & & AN-103 salt solution and AN-105 simulant spiked with rhenium \\
\hline & & $\begin{array}{l}\text { WSRC-TR-2000-00420, Superlig } 639 \text { Intermediate - Scale Ion } \\
\text { Exchange Removal of Cesium and Technetium from Hanford Tank } \\
\text { AN-102 }\end{array}$ & $\mathrm{X}$ & & & & & Envelope C salt solution from Hanford Tank 241-AN-102 \\
\hline & & $\begin{array}{l}\text { WSRC-MS-2003-00792, Column Performance Testing of SuperLig } \\
639 \text { resin with simulated Hanford waste supernates: identification } \\
\text { of the primary sorbing species and detailed characterization of } \\
\text { their desportion profiles }\end{array}$ & & & $\mathrm{x}$ & & & \\
\hline & & $\begin{array}{l}\text { WSRC-TR-2000-00419, Small-Scale Ion Exchange Removal of } \\
\text { Cesium and Technetium from Envelope B Hanford Tank 241-AZ- } \\
102\end{array}$ & $\mathrm{x}$ & & & & & Envelope B salt solution from Hanford Tank AZ-102 \\
\hline & & $\begin{array}{l}\text { WSRC-MS-2001-00760, Technetium Removal from Hanford and } \\
\text { Savannah River Site Actual Tank Waste Supernates with SuperLig } \\
639 \text { Resin, Westinghouse Savannah River Co., Aiken, South } \\
\text { Carolina, } 2001 \text {. }\end{array}$ & $\mathrm{x}$ & & & & & AN-103 \\
\hline & & $\begin{array}{l}\text { WSRC-TR-2000-00302, BNF-003-98-0153, Summary of Testing of } \\
\text { SuperLig@ } 639 \text { at the TFL Ion Exchange Facility, Savannah River } \\
\text { Technology Center, Westinghouse Savannah River Company, } \\
\text { Aiken, South Carolina, } 2000 \text {. }\end{array}$ & & & $\mathrm{x}$ & & & \\
\hline & & $\begin{array}{l}\text { WSRC-MS-2001-00573, SuperLig® } 639 \text { Equilibrium Sorption } \\
\text { data for Technetium from Hanford Tank Waste Supernates, } \\
\text { Westinghouse Savannah River Company, Aiken, South Carolina, } \\
2001 \text {. }\end{array}$ & $\mathrm{x}$ & & & & & $\mathrm{AN}-103, \mathrm{AZ}-102$, and $\mathrm{AN}-102$ \\
\hline & & $\begin{array}{l}\text { WSRC-TR-2000-00303, Rev 0, Demonstration of an Ion Exchange } \\
\text { Resin Addition/Removal System with SuperLig } ® 659 \text {, } \\
\text { Westinghouse Savannah River Company, Aiken, South Carolina, } \\
2000 \text {. }\end{array}$ & & & & & $\mathrm{x}$ & $\begin{array}{l}\text { Demonstration of slurry transport of resin media; SuperLig } 659 \text { was used in } \\
\text { place of SuperLig } 639 \text {. }\end{array}$ \\
\hline & & $\begin{array}{l}\text { WSRC-TR-2000-00305, Preliminary Ion Exchange Modeling for } \\
\text { Removal of Technetium from Hanford Waste Using SuperLig } ₫ 639 \\
\text { Resin }\end{array}$ & & & & & & \\
\hline
\end{tabular}


RPP-RPT-50122

Appendix A - Sorption Media Reference Matrix

\begin{tabular}{|c|c|c|c|c|c|c|c|c|}
\hline $\begin{array}{l}\text { Ion Exchange / Sorbent } \\
\text { Media }\end{array}$ & Disposition & References & $\begin{array}{l}\text { Hanford } \\
\text { Tank } \\
\text { Waste }\end{array}$ & $\begin{array}{c}\text { Hanford Tank } \\
\text { waste } \\
\text { simulant } \\
\text { spiked with } \\
\text { Tc }\end{array}$ & $\begin{array}{c}\text { Hanford tank } \\
\text { waste simulant } \\
\text { with } \operatorname{Re}(\text { as a } \\
\text { surrogate for Tc) }\end{array}$ & $\begin{array}{l}\text { DOE Radioactive } \\
\text { tank waste from } \\
\text { another site }\end{array}$ & Other & Comments \\
\hline & & $\begin{array}{l}\text { WSRC-TR-2002-00495, Rev 0, Evaluating the Effects of Tri-Butyl } \\
\text { Phosphate (TBP) and Normal Paraffin Hydrocarbon (NPH) in } \\
\text { Simulated Low-Activity Waste Solution on Ion Exchange }\end{array}$ & & & $\mathrm{x}$ & & & $\begin{array}{l}\text { Testing the influence of two organics, TBP and NPH, on SuperLig } 639 \\
\text { performance. }\end{array}$ \\
\hline & & $\begin{array}{l}\text { WTP-RPT-024, Rev 0, PNWD-3239, Rev 0, Radiation Stability } \\
\text { Testing of SuperLig®639 and SuperLig®644 Resins }\end{array}$ & & & & & & \\
\hline & & $\begin{array}{l}\text { BNF-003-98-0219, Small-Scale Ion Exchange Removal of Cesium } \\
\text { and Technetium from Hanford Tank 241-AN-102 }\end{array}$ & $\mathrm{x}$ & & & & & \\
\hline & & $\begin{array}{l}\text { PNWD-3251, WTP-RPT-026 Equilibrium Batch Contact Testing of } \\
\text { SuperLig } 639\end{array}$ & & & & & $\mathrm{x}$ & \\
\hline & & $\begin{array}{l}\text { PNWD-3222, WTP-RPT-030 Rev 0, Small Column Testing of } \\
\text { SuperLig 639 for Removing Tc99 from Hanford Tank Waste } \\
\text { Envelope A (Tank 241-AP-101) }\end{array}$ & $\mathrm{x}$ & & & & & \\
\hline & & $\begin{array}{l}\text { PNWD-3252, WTP-RPT-031, Small Column Testing of Superlig } \\
639 \text { for Removing Tc } 99 \text { from Hanford Tank Waste } 241 \text {-AN-102 } \\
\text { Supernate (Envelope C) mixed with Tank } 241 \text {-C-104 Solids } \\
\text { (Envelope D) Wash and Permeate Solutions }\end{array}$ & $\mathrm{X}$ & & & & & \\
\hline & & $\begin{array}{l}\text { PNWD-3345, WTP-RPT-047, Chemical Degradation of Superlig } \\
639 \text { Ion Exchange Resin }\end{array}$ & & $\mathrm{x}$ & & & & Simulated LAW based on AN-105 \\
\hline & & $\begin{array}{l}\text { PNWD-3281, WTP-RPT-058, Small Column Testing of Superlig } \\
639 \text { for Removing Tc99 from Hanford Tank Waste Envelope B } \\
\text { (Tank 241-AZ-101) }\end{array}$ & $\mathrm{x}$ & & & & & \\
\hline & & $\begin{array}{l}\text { PNWD-3037, BNFL-RPT-028 Rev. 0, Analysis of Spent Ion } \\
\text { Exchange Media: SuperLig } 639 \text { and SuperLig } 644\end{array}$ & $\mathrm{X}$ & & & & & samples from Tanks 241-AW- 101 and 24 1-AN-1 07 \\
\hline & & $\begin{array}{l}\text { BNF-003-98-0230, Intermediate-Scale Ion Exchange Removal of } \\
\text { Technetium from Savannah River Site Tank } 44 \text { F Supernate } \\
\text { Solution }\end{array}$ & & & & $\mathrm{x}$ & & \\
\hline & & $\begin{array}{l}\text { BNF 003-98-0140, Evaluation of SuperLig } 639 \text { Ion Exchange } \\
\text { Resinfor the Removal of Rhenium from Hanford Envelope } A \\
\text { Simulant }\end{array}$ & & & $\mathrm{x}$ & & & \\
\hline & & $\begin{array}{l}\text { SRTC-BNFL-013, Evaluation of Radiation Stability of SuperLig } \\
639\end{array}$ & & & $\mathrm{x}$ & & & \\
\hline
\end{tabular}


RPP-RPT-50122

Appendix A - Sorption Media Reference Matrix

\begin{tabular}{|c|c|c|c|c|c|c|c|c|}
\hline $\begin{array}{c}\text { Ion Exchange / Sorbent } \\
\text { Media }\end{array}$ & Disposition & References & $\begin{array}{l}\text { Hanford } \\
\text { Tank } \\
\text { Waste }\end{array}$ & $\begin{array}{l}\text { Hanford Tank } \\
\text { waste } \\
\text { simulant } \\
\text { spiked with } \\
\text { Tc }\end{array}$ & $\begin{array}{c}\text { Hanford tank } \\
\text { waste simulant } \\
\text { with } \operatorname{Re}(\text { as a } \\
\text { surrogate for Tc) }\end{array}$ & $\begin{array}{c}\text { DOE Radioactive } \\
\text { tank waste from } \\
\text { another site }\end{array}$ & Other & Comments \\
\hline & & $\begin{array}{l}\text { WSRC-TR-2000-00424, ART-RPP-2000-00024 Tank 241-AZ-102 } \\
\text { Superlig 639 Technetium Ion Exchange Eluate Evaporation Study }\end{array}$ & $\mathrm{x}$ & & & & & \\
\hline & & $\begin{array}{l}\text { WSRC-TR-2003-00098, Rev 1, (SRT-RPP-2003-00026, Rev 1), } \\
\text { Multiple Ion Exchange Column Runs for Cesium and Technetium } \\
\text { Removal from AW-101 Waste Sample (U) }\end{array}$ & $\mathrm{x}$ & & & & & \\
\hline & & $\begin{array}{l}\text { PNWD-2467, BNFL-RPT-009, Ion Exchange Distribution } \\
\text { Coefficients for Cs137 and Tc99 removal from Hanford Tank } \\
\text { Supernatants } A W-101 \text { (Envelope A) and AN-107 (Envelope C) }\end{array}$ & $\mathrm{x}$ & $\mathrm{x}$ & & & & \\
\hline & & $\begin{array}{l}\text { WSRC-MS-2003-00789, Multiple Ion Exchange Column Tests for } \\
\text { Technetium Removal from Hanford Tank Waste Supernate }\end{array}$ & $\mathrm{x}$ & & & & & AW-101 sample \\
\hline & & $\begin{array}{l}\text { BNFL-RPT-022, Rev. 0, Small Column Testing of Superlig } 639 \text { for } 2 \\
\text { Removing 99Tc from Hanford Tank Waste Envelop C (Tank } 241 \text { - } \\
\text { AN-107) }\end{array}$ & $\mathrm{X}$ & & & & & \\
\hline & & $\begin{array}{l}\text { BNF-003-98-0146, Rev. 1, Small Scale Ion Exchange Removal of } \\
\text { Cesium and Technetium from Hanford Tank } 241-A N-103\end{array}$ & $\mathrm{x}$ & & & & & \\
\hline \multirow[t]{3}{*}{ Sybron ${ }^{\mathrm{TM}^{22}}$ Ionac SR-3 } & \multirow{3}{*}{$\begin{array}{l}\text { Not Selected } \\
\text { for Review } \\
\text { (WTP } \\
\text { Screening) }\end{array}$} & $\begin{array}{l}\text { LA-12654, Rev., Distributions of } 14 \text { Elements on } 63 \text { Absorbers } \\
\text { from Three Simulant Solutions (Acid-Dissolved Sludge, Acidified } \\
\text { Supernate, and Alkaline Supernate) for Hanford HLW Tank 102-SY }\end{array}$ & & $\mathrm{x}$ & & & & \\
\hline & & $\begin{array}{l}\text { LA-12863, Distributions of } 15 \text { Elements on } 58 \text { Absorbers from } \\
\text { Simulated Hanford Double-shell Slurry Feed (DSSF) }\end{array}$ & & $\mathrm{x}$ & & & & \\
\hline & & $\begin{array}{l}\text { LA-12889, Distributions of } 12 \text { Elements on } 64 \text { Absorbers from } \\
\text { Simulated Hanford Neutralized Current Acid Waste (NCWA), }\end{array}$ & & $\mathrm{x}$ & & & & \\
\hline \multirow[t]{2}{*}{ Sybron Ionac SR-6 } & \multirow{2}{*}{$\begin{array}{l}\text { Not Selected } \\
\text { for Review } \\
\text { (WTP } \\
\text { Screening) }\end{array}$} & $\begin{array}{l}\text { LA-12654, Rev., Distributions of } 14 \text { Elements on } 63 \text { Absorbers } \\
\text { from Three Simulant Solutions (Acid-Dissolved Sludge, Acidified } \\
\text { Supernate, and Alkaline Supernate) for Hanford HLW Tank 102-SY }\end{array}$ & & $\mathrm{x}$ & & & & \\
\hline & & $\begin{array}{l}\text { LA-12863, Distributions of } 15 \text { Elements on } 58 \text { Absorbers from } \\
\text { Simulated Hanford Double-shell Slurry Feed (DSSF) }\end{array}$ & & $\mathrm{x}$ & & & & \\
\hline
\end{tabular}

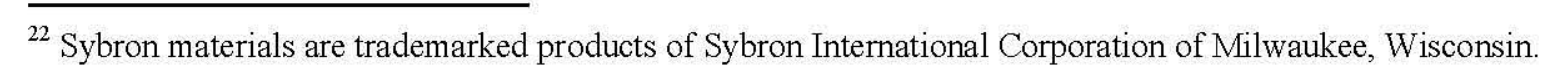


RPP-RPT-50122

Appendix A - Sorption Media Reference Matrix

\begin{tabular}{|c|c|c|c|c|c|c|c|c|}
\hline $\begin{array}{l}\text { Ion Exchange / Sorbent } \\
\text { Media }\end{array}$ & Disposition & References & $\begin{array}{l}\text { Hanford } \\
\text { Tank } \\
\text { Waste }\end{array}$ & $\begin{array}{c}\text { Hanford Tank } \\
\text { waste } \\
\text { simulant } \\
\text { spiked with } \\
\text { Tc }\end{array}$ & $\begin{array}{c}\text { Hanford tank } \\
\text { waste simulant } \\
\text { with } \operatorname{Re} \text { (as a } \\
\text { surrogate for Tc) }\end{array}$ & $\begin{array}{l}\text { DOE Radioactive } \\
\text { tank waste from } \\
\text { another site }\end{array}$ & Other & Comments \\
\hline & & $\begin{array}{l}\text { LA-12889, Distributions of } 12 \text { Elements on } 64 \text { Absorbers from } \\
\text { Simulated Hanford Neutralized Current Acid Waste (NCWA), }\end{array}$ & & $\mathrm{x}$ & & & & \\
\hline Sybron Ionic SR-7 & $\begin{array}{l}\text { Not Selected } \\
\text { for Review } \\
\text { (SME) }\end{array}$ & $\begin{array}{l}\text { RPP-RPT-23199, Rev } 0 \text { The Removal of Technetium-99 from the } \\
\text { Effluent Treatment Facility Basin } 44 \text { Waste Using Prolite A-530E, } \\
\text { Reillex HPQ, and Sybron IONAC SR-7 Ion Exchange Resins }\end{array}$ & & & & & $\mathrm{x}$ & ETF Basin 44 Reverse Osmosis (RO) reject stream \\
\hline TEVA $^{23}$ & $\begin{array}{l}\text { Not Selected } \\
\text { for Review } \\
\text { (WTP } \\
\text { Screening) }\end{array}$ & & & & & & & \\
\hline TRU-SPEC ${ }^{24}$ & $\begin{array}{l}\text { Not Selected } \\
\text { for Review } \\
\text { (WTP } \\
\text { Screening) }\end{array}$ & $\begin{array}{l}\text { LA-12654, Rev., Distributions of } 14 \text { Elements on } 63 \text { Absorbers } \\
\text { from Three Simulant Solutions (Acid-Dissolved Sludge, Acidified } \\
\text { Supernate, and Alkaline Supernate) for Hanford HLW Tank 102-SY }\end{array}$ & & & & & & \\
\hline $\begin{array}{l}\text { Zero-valence Iron } \\
\text { filings/beads }\end{array}$ & $\begin{array}{l}\text { Not Selected } \\
\text { for Review } \\
\text { (WTP } \\
\text { Screening) }\end{array}$ & & & & & & & \\
\hline
\end{tabular}

\footnotetext{
${ }^{23}$ No trademarked or proprietary information located.
}

${ }^{24}$ No trademarked or proprietary information located. 
RPP-RPT-50122

\section{APPENDIX B VENDOR INFORMATION}

Figure B-1. ABECTM 2000 Page 1

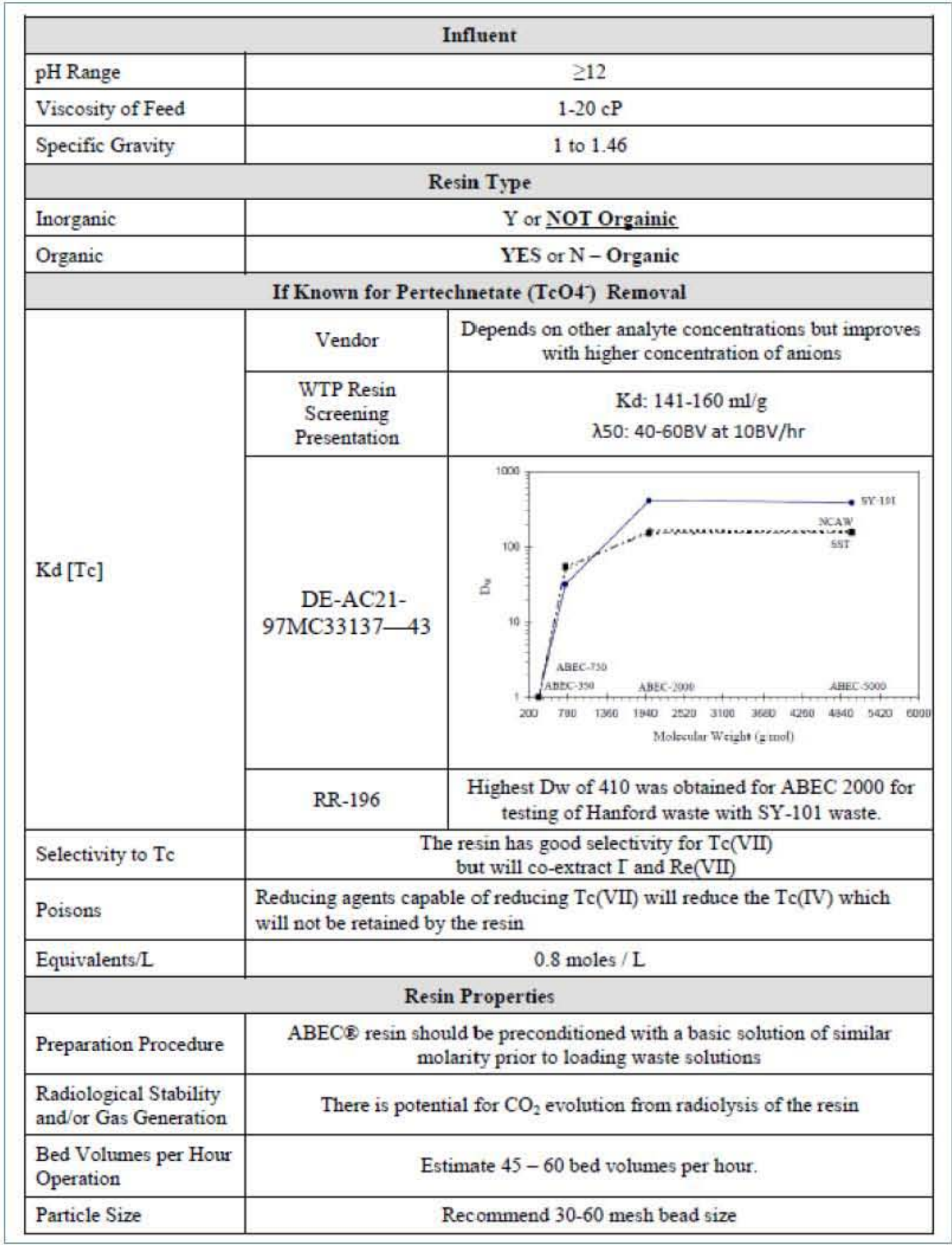


RPP-RPT-50122

Appendix B - Sorption Media Reference Matrix

Figure B-2. ABECTM 2000 Page 2

\begin{tabular}{|c|c|}
\hline Elutable & YES or $\mathrm{N}$ \\
\hline Eluant & Water, dilute saline or dilute acid \\
\hline Storage, Shelf Life & $\begin{array}{l}\text { Anticipate greater than } 2 \text { years of shelf life } \\
\text { under environmentally controlled conditions. }\end{array}$ \\
\hline $\begin{array}{l}\text { Handling } \\
\text { Specifications }\end{array}$ & $\begin{array}{l}\text { Resin will shrink and swell up to } 30 \% \text { depending on ionic strength of solutions } \\
\text { passed through the resin bed. }\end{array}$ \\
\hline Loading Cycles & $\begin{array}{l}\text { Estimate } 20 \text { loading cycles for the resin but actual results will depending on } \\
\text { the effects of radiolytic damage to the resin. }\end{array}$ \\
\hline $\begin{array}{l}\text { Resin Density (weight } \\
\text { per unit volume) }\end{array}$ & $0.8 \mathrm{~g} / \mathrm{mL}$ in $\mathrm{H}_{2} \mathrm{O}$ and $1.1 \mathrm{~g} / \mathrm{mL}$ in $6 \mathrm{M} \mathrm{KOH}$ \\
\hline $\mathrm{pH}$ operating range & $\mathrm{pH} 6$ to $14+$ \\
\hline $\begin{array}{l}\text { Temperature operating } \\
\text { range }\end{array}$ & $10^{\circ} \mathrm{C}-50^{\circ} \mathrm{C}$ \\
\hline Cost per Pound (or $\left.\mathrm{ft}^{3}\right)$ & See attached quotation \\
\hline $\begin{array}{l}\text { Ability to supply } \\
\text { amounts of } \geq 2000 \mathrm{lbs}\end{array}$ & $\begin{array}{l}\text { Will require scale up development } \\
\text { but is technological possible. }\end{array}$ \\
\hline \multicolumn{2}{|c|}{ Vendor:_Eichrom Technologies LLC, Lisle, IL_Resin:_ABECE-2000__ } \\
\hline Contact Name/Phone, & imail:_Terence O'Brien, 630-963-0320, tobrien@eichrom.com \\
\hline
\end{tabular}




\section{RPP-RPT-50122 \\ Appendix B - Sorption Media Reference Matrix}

Figure B-3. DOWEX® 1-X8, Aldrich $($ Page 1 of 3

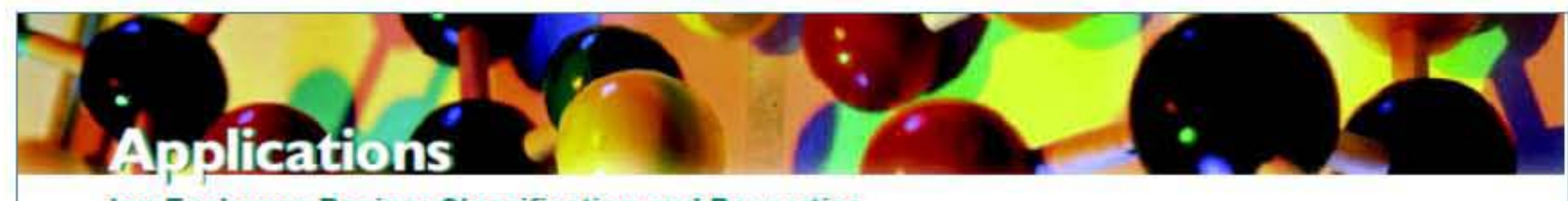

Ion Exchange Resins: Classification and Properties

Ion exchange resins are highly ionic, covalently cross-linked, insoluble polyelectrolytes supplied as beads. The beads have either a dense intemal structure with no discrete pores (gel resins, also called microporous resins) or a porous, muitichannelled structure (macroporous or macroreticular resins). They are commonly prepared from styrene and various levels of the cross-linking agent divinyl benzene, which controls the porosity of the particles. Porous beads can be made also by adding homopolystrene, which is soluble in the monomer mixture, and leaching it out later with, toluene, for instance. The PS-DVB precursor beads are post-functionalized to yield the finished resin. Acrylic based, ion exchange resins are also available (see Table I). These ionic polymers contain two types of ions, those which are bound within the structure and the oppositely charged counter ions which are free. The property of ion exchange is a consequence of Donnan exclusion - when the resin is immersed in a medium in which it is insoluble, the counter ions are mobile and can be exchanged for other counter ions from the surrounding medium; ions of the same type of charge as the bound ions do not have free movement into and out of the polymer. Ion exchange resins have been classified based on the charge on the exchangeable counterion (cation exchanger or anion exchanger) and the ionic strength of the bound ion (strong exchanger or weak exchanger). Thus, there are four primary types of ion exchange resins:

1. Strong cation exchange resins, containing sulfonic acid groups or the corresponding salts.

2. Weak cation exchange resins, containing carboxylic acid groups or the corresponding salts.

3. Strong anion exchange resins, containing quarternary ammonium groups. Of these, there are two types: Type I resins contain trialkyl ammonium chloride or hydroxide and Type $\|$ resins contain dialkyl 2-hydroxyethyl ammonium chloride or hydroxide.

4. Weak anion exchange resins, containing ammonium chloride or hydroxide.

Additional types of ion exchange resins include blends of cation and anion exchange resins, called mixed bed resins.
A resin which contains both an anion and a cation as bound ions is said to be ampholytic. Some ion exchange resins are prepared with chelating properties making them highly selective towards certain ions. In addition to their use in ion exchange, organic polymer supports, many of which are based on PS-DVB resins, are being used as polymeric catalysts in the expanding research area involving heterogenization of homogenous catalysts and as polymeric supports and reagents in combinatorial chemistry.

The internal structure of the resin beads, i.e., whether microporous (gel-type) or macroporous, is important in the selection of an ion exchanger. Macroporous resins, with their high effective surface area, facilitate the ion exchange process. Also, they give access to the exchange sites for larger ions, can be used with almost any solvent, irrespective of whether it is a good solvent for the uncrosslinked polymer, and take up the solvent with little or no change in volume. They make more rigid beads, facilitating ease of removal from the reaction system. In the case of the microporous resins, since they have no discrete pores, solute ions diffuse through the particle to interact with exchange sites. Despite diffusional limitations on reaction rates, these resins offer certain advantages: they are less fragile, requiring less care in handling, react faster in functionalization and applications reactions, and possess higher loading capacities.

In addition to being a function of bead morphology, the kinetics of the exchange depends on the particle size distribution of the resin. It is enhanced by a monodisperse resin, for example, see the Marathon ${ }^{\oplus}$ and Amberjet resins in Table $\mathrm{l}$; they permit faster elution and regeneration times with reduced back pressure.

To help you select an exchanger or combination of exchangers, Table I provides a compilation of ion exchange resins offered by Aldrich, classified by type, as defined above, along with characteristics of each resin such as particle size, functional group, ionic form (i.e., the counterion), exchange capacity, and operating conditions. For additional information on ion exchange resins from Aldrich, please request Aldrich Technical Bulletin AL-142. For additional information on polymenic supports, please refer to the Apolications Section.

Table I: Classification and Properties of Numerous Ion Exchange Resins offered by Aldrich

\begin{tabular}{|c|c|c|c|c|c|c|c|c|c|c|}
\hline \multirow[t]{2}{*}{ Cat. No. } & \multirow[t]{2}{*}{ Exchanger } & \multirow{2}{*}{$\begin{array}{l}\text { \% cross- } \\
\text { linking }\end{array}$} & \multirow[t]{2}{*}{ Matrix't } & \multirow{2}{*}{$\begin{array}{c}\text { Meshy } \\
\text { Bead size }\end{array}$} & \multirow{2}{*}{$\begin{array}{l}\text { lonic } \\
\text { Form }\end{array}$} & \multirow{2}{*}{$\begin{array}{c}\% \\
\text { Moisture }\end{array}$} & \multirow{2}{*}{$\begin{array}{l}\text { Max Op. } \\
\text { Tenp. "C }\end{array}$} & \multicolumn{2}{|c|}{ Total Exchange Capacity } & \multirow[t]{2}{*}{ pH range } \\
\hline & & & & & & & & meq/mi & mecig & \\
\hline \multicolumn{11}{|c|}{ Strong Cation Exchangers on Polystyrene } \\
\hline \multicolumn{3}{|c|}{ Amberlite ${ }^{*} /$ Amberlyst $^{*} / A m b e r j e t^{*}$} & \multicolumn{8}{|c|}{ (Sulfonic Acid) } \\
\hline $22,435-9$ & IR-120 Plus & - & G & $16-50$ & $\mathrm{Na}$ & 45 & 120 & 1.9 & 4.4 & $0-14$ \\
\hline $27.427-5$ & IRP-69 & - & - & $25-150 \mu \mathrm{m}$ & $\mathrm{Na}$ & 10 & - & - & - & - \\
\hline $21.638-0$ & 15 & - & $M p$ & $16-50$ & H & $<1$ & 120 & 2.8 & 4.7 & $0-14$ \\
\hline
\end{tabular}


RPP-RPT-50122

Appendix B - Sorption Media Reference Matrix

Figure B-4. DOWEX $\left(\right.$ 1-X8, Aldrich ${ }^{\circledR}$ Page 2 of 3

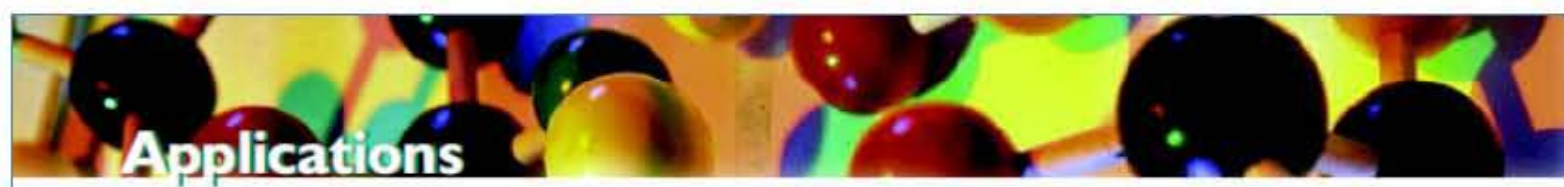

Table I: Classification and Properties of Numerous lon Exchange Resins offered by Aldrich (continued)

\begin{tabular}{|c|c|c|c|c|c|c|c|c|c|c|}
\hline \multirow{2}{*}{ Cat No } & \multirow[t]{2}{*}{ Exchanger } & \multirow{2}{*}{$\begin{array}{l}\text { \% cross- } \\
\text { linking }\end{array}$} & \multirow[t]{2}{*}{ Matrix } & \multirow{2}{*}{$\begin{array}{c}\text { Meshy } \\
\text { Bead sine }\end{array}$} & \multirow{2}{*}{$\begin{array}{l}\text { lonic } \\
\text { Form }\end{array}$} & \multirow{2}{*}{$\begin{array}{c}\text { \% } \\
\text { Moisture }\end{array}$} & \multirow{2}{*}{$\begin{array}{l}\text { Max Op: } \\
\text { Tennp. "C }\end{array}$} & \multicolumn{2}{|c|}{ Total Exchunge Capacily } & \multirow[t]{2}{*}{ pH range } \\
\hline & & & & & & & & megimi & megia & \\
\hline \multicolumn{11}{|c|}{ Strong Cation Exchangers on Polystyrene (continued) } \\
\hline \multicolumn{11}{|c|}{ Dowex" (Sulfonic Acid) } \\
\hline & $50 W \times 2-100$ & 2 & Q & $50-100$ & $\mathrm{H}$ & 78 & 150 & 0.6 & 4.8 & $0-14$ \\
\hline$\frac{21,746-8}{217476}$ & $\begin{array}{l}50 W \times 2.200 \\
50 w 02.400\end{array}$ & $\frac{2}{2}$ & G & $\begin{array}{l}100-200 \\
200-400\end{array}$ & $\mathrm{H}_{\mathrm{H}}^{\mathrm{H}}$ & 78 & 160 & 0.6 & $\begin{array}{l}4.8 \\
4.8\end{array}$ & $0-14$ \\
\hline$\frac{21}{42,82-0}-\frac{5}{4}$ & $50 W \times 4.500$ & $\frac{2}{4}$ & G & $20-500$ & $\mathrm{H}$ & 68 & 150 & 1.1 & $\begin{array}{ll}4.8 \\
4.8\end{array}$ & $0-14$ \\
\hline$\frac{42.8693}{422096}$ & $50 W \times 4-100$ & 4 & $G$ & $50-100$ & H & 88 & 150 & 11 & 4.8 & $0-14$ \\
\hline$\frac{42,2098-6}{42,87-1}$ & ${ }_{50 W \times 4-200 R}^{50 W \times 4.200}$ & $\begin{array}{l}4 \\
4\end{array}$ & $G$ & $\begin{array}{l}100-200 \\
100-200\end{array}$ & $\mathrm{H}_{\mathrm{H}}^{\mathrm{H}}$ & $\begin{array}{l}68 \\
68\end{array}$ & $\begin{array}{l}150 \\
130\end{array}$ & 11 & $\begin{array}{l}4.8 \\
4.8\end{array}$ & $\begin{array}{l}0.14 \\
0-14\end{array}-14$ \\
\hline$\frac{721748-1}{217402}$ & $50 W \times 4.400$ & 4 & G & $200-400$ & H & 68 & 150 & 1.1 & 4.8 & $0-14$ \\
\hline$\frac{21.749-2}{21.750-0}$ & $50 W \times 8-100$ & 8 & $\mathrm{G}$ & $50-100$ & $\mathrm{H}$ & 53 & 150 & 1.7 & 4.8 & $0-14$ \\
\hline$\frac{21.750-8}{21,751-4}$ & $\begin{array}{l}50 W \times 8.200 \\
50 W \times 8.400\end{array}$ & $8_{8}^{8}$ & $G_{G}^{G}$ & $\begin{array}{l}100-200 \\
200-400\end{array}$ & H & $\begin{array}{l}54 \\
54\end{array}$ & $\begin{array}{l}150 \\
150\end{array}$ & 17 & $\begin{array}{l}4.8 \\
4.8\end{array}$ & $0-14$ \\
\hline$\frac{42.872 .8}{42978}$ & HCR.S & 8 & G & $20-50$ & $\mathrm{H}$ & 53 & 16 & 1.8 & 4.8 & $0-14$ \\
\hline$\frac{42870-1}{43808-2}$ & HCR-W2 & $B$ & is & $16-40$ & $\mathrm{H}$ & $\begin{array}{l}52 \\
45\end{array}$ & 150 & 18 & 4.8 & $0-14$ \\
\hline$\frac{\frac{73,0052}{43.601 .5}}{4.5}$ & $650 \mathrm{C}$ & & G & $25 \cdot 30$ & $\mathrm{Na}_{\mathrm{H}}$ & $\begin{array}{l}40 \\
50\end{array}$ & 15 & 1.8 & & \\
\hline 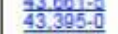 & Marathon C & : & G & $30-40$ & $\mathrm{H}$ & 53 & $\begin{array}{l}15 \\
14\end{array}$ & 1.8 & 2.6 & $0-14$ \\
\hline 42.878 .7 & MSC-1 & - & - & $20-50$ & $\mathrm{Na}$ & 47 & 150 & 1.7 & 4.5 & $0-14$ \\
\hline \multicolumn{11}{|c|}{ Duolite' (Sulfonic Acid) } \\
\hline $43,609-0$ & $C-20$ & - & Mp & $520 \mu \mathrm{m}$ & $\mathrm{Na}$ & 50 & 150 & 1.8 & - & $0-14$ \\
\hline
\end{tabular}

Weak Cation Exchangers on Polyacrylic

Amberlite* (Carboxylic Acid)

\begin{tabular}{|c|c|c|c|c|c|c|c|c|c|c|}
\hline $21.635-6$ & CG.50 Type I & 4 & Mp & $100-200$ & $\mathrm{H}$ & 5 & 120 & 3.5 & 10.0 & $5-14$ \\
\hline $42,883-3$ & IRC- 50 & 4 & Mp & $16-50$ & $\mathrm{H}$ & 48 & 120 & 3.5 & 100 & $5-14$ \\
\hline $21.657-7$ & IRC-50S & - & $\mathrm{Mp}$ & $400 \mu \mathrm{m}$ & $\mathrm{H}$ & 48 & 120 & 3.5 & - & $5-14$ \\
\hline $27,426-7$ & IRP-64 & - & Mp & $100-400$ & $\mathrm{H}$ & 5 & - & - & 10.0 & - \\
\hline \multicolumn{11}{|c|}{ Dowex" (Carboxylic Acid) } \\
\hline $42,881-7$ & CCR-3 & - & - & $20-50$ & $\mathrm{H}$ & 50 & 120 & 3.8 & - & - \\
\hline
\end{tabular}

Strong Anion Exchangers on Polystyrene

Amberlite* Strong Anion Exchangers, Type I (Trialkylbenzyl Ammonium)

$\begin{array}{lllllll}24.700-9 & \text { IRA.400(Cl) } & B & G & 16-50 & \text { Cl } & 45\end{array}$

21.8445 IRA.743 - $\quad G \quad 450 \mu \mathrm{m}$ OH 59

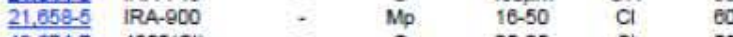

43.6747 4200(Cl)

$25-25 \quad$ Cl

$\begin{array}{ll}45 & 77 \\ 17 & 77\end{array}$

Dowex* Type 1 (Trimethylbenzyl Ammonium)

$21.737-9 \quad 1 \times 2-100$

$\frac{21.737-9}{21.738-7} \quad 1 \times 2-100$

$\frac{21.730-5}{1 \times 2-400}$

$42,801-2$

$1 \times 4-50$

$42.858-2 \quad 1 \times 4-100$

$42.850-0$

$1 \times 4-100$
$1 \times 4-200$

$1 \times 4-200$
$1 \times 4-400$

42.8604

$21.740-9$

$1 \times 8-50$

$\frac{21.741-7}{21.742-5} \quad 1 \times 8-100$

$21743.3 \quad 1 \times 8-400$

$42,87 \theta-0$ MSA-1

$43.605-9 \quad 21 \mathrm{~K}$

$43,660-7 \quad 5504$

43.394 - Marathon A

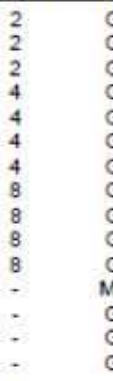

50-100

$100-200$

$200-400$

20-50

$50-100$

$100-200$

$200-400$

20-50

50-100

$100-200$

$200-400$

$20-50$

$16-30$

$25-35$
$30-40$

Cl 70

(20)

$50 \quad 12$

$1.4 \quad 3.8$

$0.6 \quad-$

4.2
3.7

Amberlite*, Type II (Dimethyl-2-hydroxyethylbenzyl Ammonium)

21.656-9 IRA-410 -

20-50 C

Dowex" Type II (Dimethyl-2-hydroxyethylbenzyl Ammonium)

$\begin{array}{llllll}42.802-0 & 2 \times 8-100 & 8 & G & 50-100 & \mathrm{Cl}\end{array}$

$42,803-9 \quad 2 \times 8-200$

$42.864-7 \quad 2 \times 8-400$

42,877-9 MSA-2

Marathon A2

22

$\begin{array}{cccc}8 & G & 50-100 & C \\ 8 & G & 100-200 & C \\ 8 & G & 200-400 & C \\ \therefore & M p & 16-50 & C \\ - & G & 30-40 & C \\ - & M p & 20-40 & C\end{array}$

$20-40$

$\begin{array}{ll}\text { Cl } & 38 \\ \text { Cl } & 37 \\ \text { Cl } & 37 \\ \text { d } & 5 \\ \text { Cl } & 42 \\ \text { Cl } & \text { E }\end{array}$

$\begin{array}{lll}70 & 66 & 0.7 \\ 75 & 66 & 0 \\ 75 & 66 & 0 . \\ 50 & 66 & 1 . \\ 50 & 68 & 1 . \\ 50 & 66 & 1 \\ 59 & 66 & 1 . \\ 46 & 66 & 1 \\ 46 & 66 & 1 . \\ 46 & 66 & 1 \\ 46 & 66 & 1 \\ 60 & 66 & 1 \\ 54 & 60 & 1 \\ 48 & 60 & 1 . \\ 57 & 60 & 1.2\end{array}$

$\begin{array}{ll}0.7 & 3.5 \\ 0.6 & 3.5 \\ 0.6 & 3.5 \\ 1.0 & 3.5 \\ 1.0 & 3.5 \\ 1.0 & 3.5 \\ 1.0 & 3.5 \\ 1.2 & 3.5 \\ 1.2 & 3.5 \\ 1.2 & 3.5 \\ 1.2 & 3.5 \\ 1.0 & 4.0 \\ 1.2 & 3 . \\ 1.1 & 3.4 \\ 1.2 & 4.0\end{array}$

\begin{tabular}{|ll|}
3.5 & $0-14$ \\
3.5 & $0-14$ \\
3.5 & $0-14$ \\
3.5 & $0-14$ \\
3.5 & $0-14$ \\
3.5 & $0-14$ \\
3.5 & $0-14$ \\
3.5 & $0-14$ \\
3.5 & $0-14$ \\
3.5 & $0-14$ \\
3.5 & $0-14$ \\
4.0 & $0-14$ \\
3.8 & $0-14$ \\
3.4 & $0-14$ \\
4.0 & $0-14$ \\
& \\
3.4 & $0-14$ \\
& \\
\hline- & $0-14$ \\
- & $0-14$ \\
3.7 & $0-14$ \\
3.2 & $0-14$ \\
- & - \\
\hline
\end{tabular}


Figure B-5. DOWEX ${ }^{\circledR}$ 1-X8, Aldrich ${ }^{\circledR}$ Page 3 of 3

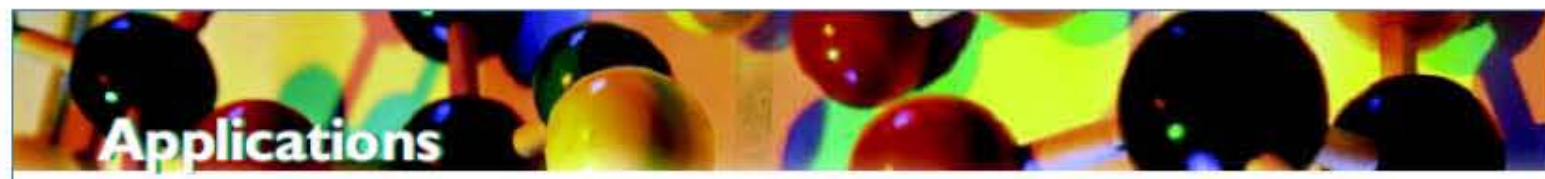

Table I: Classification and Properties of Numerous Ion Exchange Resins offered by Aldrich (continued)

\begin{tabular}{|c|c|c|c|c|c|c|c|c|c|c|}
\hline \multirow[t]{2}{*}{ Cat No. } & \multirow[t]{2}{*}{ Exchanger } & \multirow{2}{*}{$\begin{array}{l}\text { oross- } \\
\text { linking }\end{array}$} & \multirow[t]{2}{*}{ Matrix } & \multirow{2}{*}{$\begin{array}{l}\text { Meshl } \\
\text { Bead size }\end{array}$} & \multirow{2}{*}{$\begin{array}{l}\text { Ionic } \\
\text { Form }\end{array}$} & \multirow{2}{*}{$\begin{array}{c}8 \\
\text { Moisture }\end{array}$} & \multirow{2}{*}{$\begin{array}{l}\text { Max Op. } \\
\text { Tenpe }{ }^{2} \mathrm{C}\end{array}$} & \multicolumn{2}{|c|}{ Total Exchange Capacity" } & \multirow[t]{2}{*}{ pH range } \\
\hline & & & & & & & & meq/mi & meq/g & \\
\hline \multicolumn{11}{|c|}{ Weak Anion Exchangers on Polystyrene } \\
\hline \multicolumn{11}{|c|}{ Amberlite" (Polyamine) } \\
\hline $47.803-3$ & IRA-67 & - & G & $18-50$ & FB & 60 & 60 & 1.6 & 5.6 & 7.8 \\
\hline \multicolumn{11}{|c|}{ Dowex (Polyamine) } \\
\hline $42.879-5$ & WGR-2 & - & Mp & $20-50$ & $\mathrm{FB}$ & 55 & 93 & 1.9 & 6.1 & $0-7$ \\
\hline $43,687-4$ & & - & Mp & $16-50$ & FE & 45 & 80 & 1.4 & 4.0 & $0-7$ \\
\hline $43.620-8$ & Marathon WBA & - & Mp & $25-50$ & FB & 54 & 60 & 1.25 & 4.2 & $0-7$ \\
\hline \multicolumn{11}{|c|}{ Duolite" (Polyamine) } \\
\hline 43.6704 & A.7 & - & Mp & $18-50$ & FB & 56 & 40 & 22 & 13.0 & 0.6 \\
\hline
\end{tabular}

Mixed Bed Resins on Polystyrene

Dowex" Mixed Bed Resins

\begin{tabular}{lllllllllll}
$42.873-6$ & MR-3 & - & $G$ & $20-50$ & $\mathrm{H}, \mathrm{OH}$ & 50 & 50 & - & 1.7 & 0.14 \\
$42,874-4$ & MR-3C & - & $G$ & $10-45$ & $\mathrm{H}, \mathrm{OH}$ & 50 & 50 & - & 1.7 & $0-14$ \\
\hline $42.869-8$ & 11A8 Retardion & - & $G$ & $35-80$ & $\mathrm{Na}$ & 45 & 70 & $\mathrm{Na}$ & $\mathrm{Na}$ & $0-14$ \\
\hline
\end{tabular}

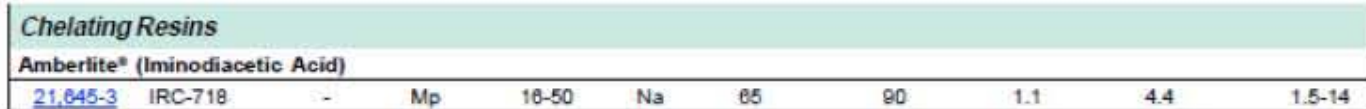

Polymeric Catalysts

Amberlyst" Strong Acid (Sulfonic Acid)

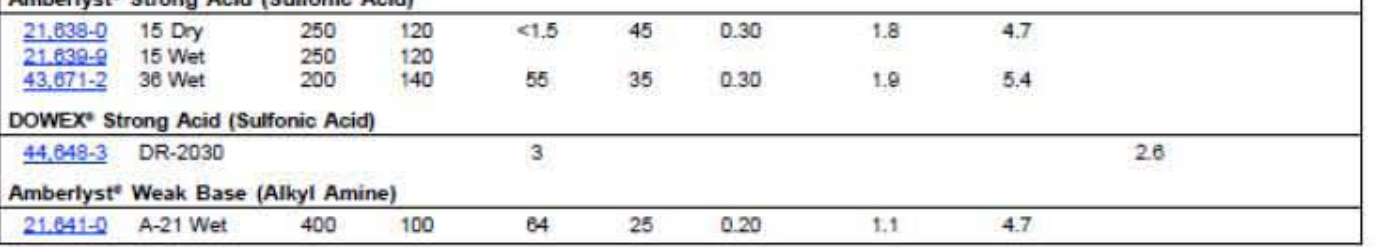

' $G$ - gel (or micropotous), Np - macroporous (or macroreticular)

'NA - not applicable

Amberjat, Amberite, Ambertyst, and Duolte are registered trademans of Rohm and Hass Co.

Dowex, Narathon, and Retardon are registered trademaris of Dow Chemical $C_{0}$. 
RPP-RPT-50122

Appendix B - Sorption Media Reference Matrix

\section{Figure B-6. DOWEX'M 1-X8 Cost from GFS Chemicals (supplier/non-bulk)}

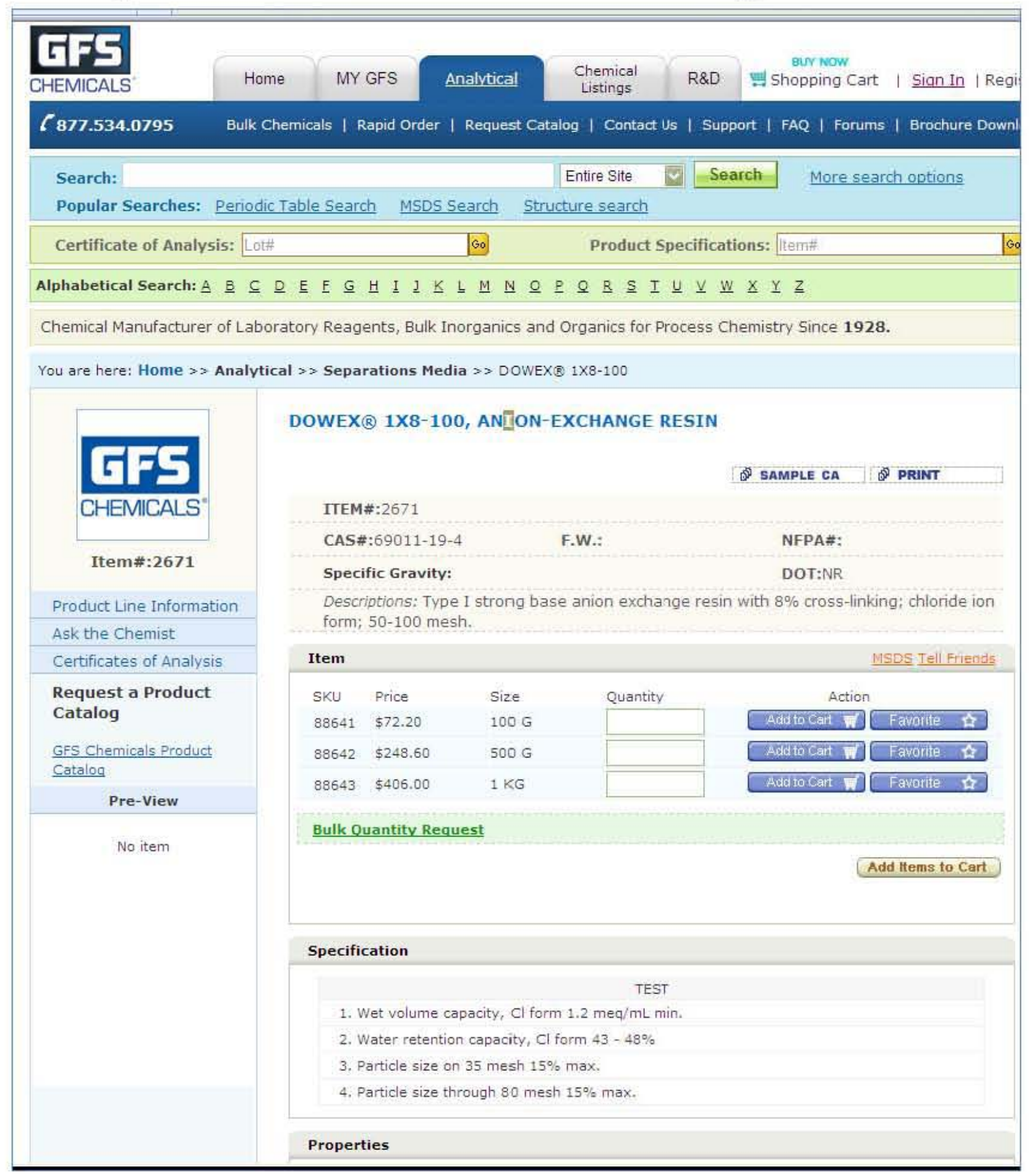




\section{RPP-RPT-50122 \\ Appendix B - Sorption Media Reference Matrix}

Figure B-7. DOWEX ${ }^{\mathrm{TM}}$ 1-X8 Supplier Information

Ion Exchange Media

DOWEX Ion Exchange Resins

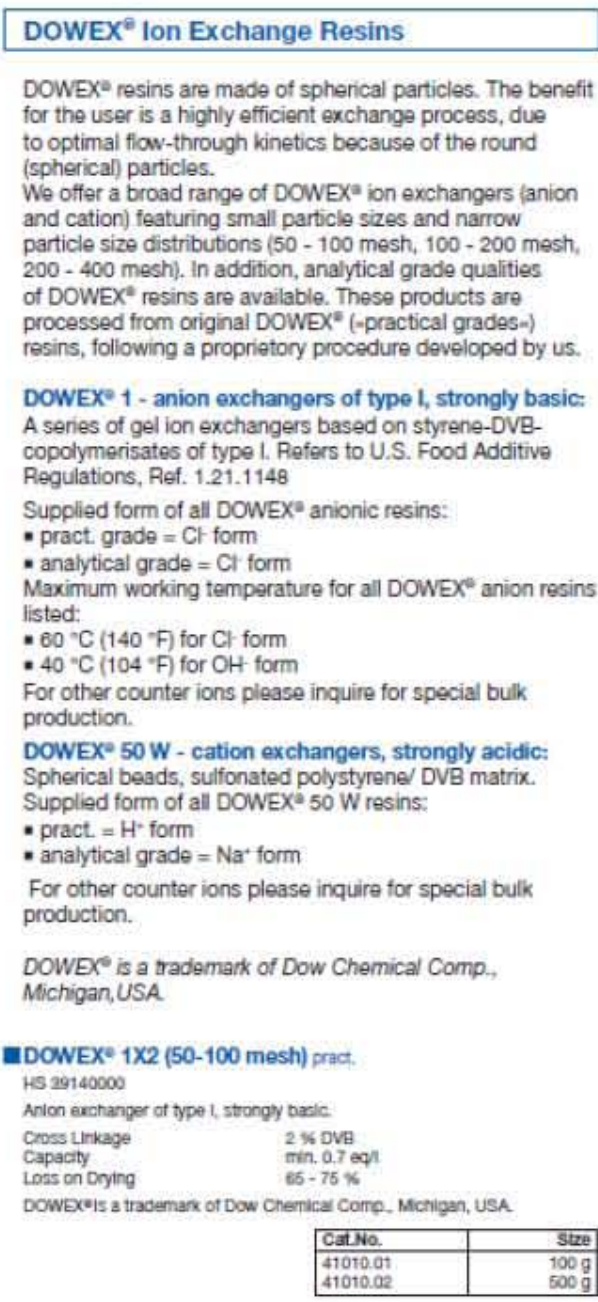

and DOWEXe 1 X2 (50-100 mesh) anaytcal gade

HS 39140000

Anlon exchanger of type 1, strangly basic.

Cross unkage $\quad 2 \%$ DVE

$\begin{array}{ll}\text { Capacity } & \min .0 .7 \mathrm{eq} / \\ \text { Loss on Dying } & 65-75 \%\end{array}$

Lass on Drying

\begin{tabular}{|l|r|}
\hline Cat No. & Size \\
\hline 41011.01 & 1000 \\
41011.02 & $500 \mathrm{~g}$ \\
\hline
\end{tabular}

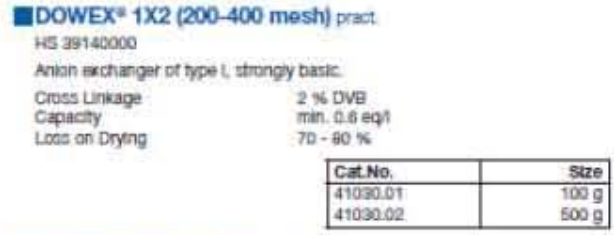

EDWEX*1X2 (200-400 mesh) ansycal grade

HS astaco00

Anion achingat of type $L$, throngy basic.

Cruss Linkage $\quad 2 \%$ DVE

$\begin{array}{ll}\text { Capacty } & \text { min. } 0.6 \mathrm{eq} \\ \text { Loes on Dryeng } & 70-60 \mathrm{~s}\end{array}$

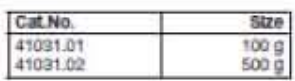

CDOWEX 1 X8 (20-50 mesh) pract.

HS 99140000

Avian ecchingar of type L, strongy basic.

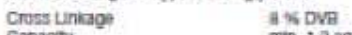

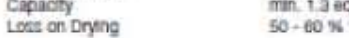

Cat.No.

\begin{tabular}{|l|r|}
\hline 47000.03 & Size \\
\hline 41000.04 & 5009 \\
\hline
\end{tabular}

aDOWEX" $1 \times 8$ (20-50 mesh) andyycal grade

HS 39140000

Avion acturger of type L, strongy basic.

Cruses Uniage : a NDVG

Capacty $\quad 1,0-1.5$ eq

$50-60 \%$

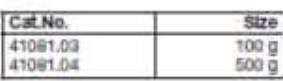

EDOWEX*1X8 (50-100 mesh) pract.

HS 39140000

Avian axchungar of tope L. atrongy basic.

Cross Linikage \# $\$$ DVE

Capacty
toms on Dryeng 1.2 ed
$43-47 \%$

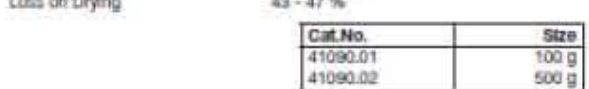

EDOWEX"1X8 (50-100 mesh) mayphcat grade

HS 39140000

Nisis exchanger of type t strongy bask.

Cross Unikage a $\$$ OVE

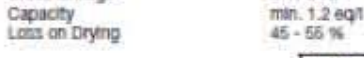

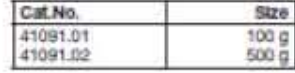




\section{RPP-RPT-50122 \\ Appendix B - Sorption Media Reference Matrix}

Figure B-8. Purolite ${ }^{T M}$ A-520E

\begin{tabular}{|c|c|}
\hline \multicolumn{2}{|c|}{ Contact Name/Phone/Email:__Steve Soldatek_ } \\
\hline \multicolumn{2}{|c|}{ Influent } \\
\hline pH Range & $\geq 12$ \\
\hline Viscosity of Feed & $1-20 \mathrm{cP}$ \\
\hline \multicolumn{2}{|c|}{ Resin Type } \\
\hline Inorganic & No \\
\hline Organic & YES - Purolite A520E \\
\hline \multicolumn{2}{|c|}{ If Known for Pertechnetate ( $\mathrm{TcO} 4$ ) Removal } \\
\hline \multicolumn{2}{|l|}{$\mathrm{Kd}[\mathrm{Tc}]$} \\
\hline \multicolumn{2}{|l|}{ Selectivity to $\mathrm{Tc}$} \\
\hline Poisons & Competing anions ( $\mathrm{SO} 4, \mathrm{Cl}, \mathrm{HCO} 3, \mathrm{NO} 3, \mathrm{U})$ \\
\hline Equivalents/L & $0.9 \mathrm{eq} / 1 \mathrm{~min}$ \\
\hline \multicolumn{2}{|c|}{ Resin Properties } \\
\hline Preparation Procedure & Backwash to classify bed and then rinse \\
\hline \multicolumn{2}{|l|}{ Radiological Stability and/or Gas Generation } \\
\hline Bed Volumes per Hour Operation & Depends on concentration of competing anions \\
\hline Particle Size & $300-1200$ micron diameter \\
\hline Elutable & No \\
\hline Eluant & No \\
\hline Storage, Shelf Life & 5 years \\
\hline \multicolumn{2}{|l|}{ Handling Specifications } \\
\hline Loading Cycles & Single use disposable resin \\
\hline Resin Density (weight per unit volume) & $675705 \mathrm{~g} / 1$ \\
\hline $\mathrm{pH}$ operating range & $0-14$ \\
\hline Temperature operating range & $5-60 \mathrm{C}$ \\
\hline \multicolumn{2}{|l|}{ Cost per Pound (or $\left.\mathrm{ft}^{3}\right)$} \\
\hline Ability to supply amounts of $\geq 2000 \mathrm{lbs}$ & Yes \\
\hline
\end{tabular}




\section{RPP-RPT-50122 \\ Appendix B - Sorption Media Reference Matrix}

Figure B-9. Purolite ${ }^{\text {TM }}$ A-530E

Vendor: The Purolite Company

Contact Name/Phone/Email: Steve Soldatek

\begin{tabular}{|c|c|}
\hline \multicolumn{2}{|c|}{ Influent } \\
\hline pH Range & $\geq 12$ \\
\hline Viscosity of Feed & $1-20 \mathrm{cP}$ \\
\hline \multicolumn{2}{|c|}{ Resin Type } \\
\hline Inorganic & No \\
\hline Organic & YES - Purolite A $530 \mathrm{E}$ \\
\hline \multicolumn{2}{|c|}{ If Known for Pertechnetate ( $\mathrm{TcO}_{4}$ ) Removal } \\
\hline \multicolumn{2}{|l|}{$\mathrm{Kd}[\mathrm{Tc}]$} \\
\hline \multicolumn{2}{|l|}{ Selectivity to Tc } \\
\hline Poisons & Competing anions ( $\mathrm{SO} 4, \mathrm{Cl}, \mathrm{HCO} 3, \mathrm{NO} 3, \mathrm{U}$ ) \\
\hline Equivalents/L & $0.6 \mathrm{eq} / 1 \mathrm{~min}$ \\
\hline \multicolumn{2}{|c|}{ Resin Properties } \\
\hline Preparation Procedure & Backwash to classify bed and then rinse \\
\hline \multicolumn{2}{|l|}{ Radiological Stability and/or Gas Generation } \\
\hline Bed Volumes per Hour Operation & Depends on concentration of competing anions \\
\hline Particle Size & $300-1200$ micron diameter \\
\hline Elutable & No \\
\hline Eluant & No \\
\hline Storage, Shelf Life & 5 years \\
\hline \multicolumn{2}{|l|}{ Handling Specifications } \\
\hline Loading Cycles & Single use disposable resin \\
\hline Resin Density (weight per unit volume) & $670 \mathrm{~g} / 1$ \\
\hline $\mathrm{pH}$ operating range & $0-14$ \\
\hline Temperature operating range & $5-60 \mathrm{C}$ \\
\hline \multicolumn{2}{|l|}{ Cost per Pound (or $\left.\mathrm{ft}^{3}\right)$} \\
\hline Ability to supply amounts of $\geq 2000 \mathrm{lbs}$ & Yes \\
\hline
\end{tabular}


RPP-RPT-50122

Appendix B - Sorption Media Reference Matrix

Figure B-10. Reillex ${ }^{\mathrm{TM}}$ HPQ (from Vertellus $(\mathbb{B}$ )

\begin{tabular}{|c|c|c|c|c|}
\hline \multicolumn{5}{|c|}{$\begin{array}{c}\text { TYPICAL PROPERTIES } \\
\text { REILLEX }^{\mathrm{TM}} \text { crosslinked poly-4-vinylpyridines }\end{array}$} \\
\hline & Reillex ${ }^{\text {nt }} 402$ & $\underline{\text { Reillex }}{ }^{\mathrm{TM}} 425$ & $\underline{\text { Reillex }}{ }^{\mathrm{TM}}$ HP & $\underline{\text { Reillex }}{ }^{\mathrm{nM}} \mathrm{HPQ}$ \\
\hline Appearance & granular powder & spherical beads & spherical beads & spherical beads \\
\hline $\begin{array}{l}\text { Weak Base } \\
\text { Capacity }\end{array}$ & $8.0 \mathrm{eq} / \mathrm{kg}$ dry & $\begin{array}{l}6.0 \mathrm{eq} / \mathrm{kg} \text { dry } \\
1.7 \mathrm{eq} / \mathrm{h} \text { wet }\end{array}$ & $\begin{array}{l}6.0 \mathrm{eq} / \mathrm{kg} \mathrm{dry} \\
1.7 \mathrm{eq} / \mathrm{l} \text { wet }\end{array}$ & N/A \\
\hline $\begin{array}{l}\text { Strong Base } \\
\text { Capacity }\end{array}$ & none & none & none & $4.0 \mathrm{eq} / \mathrm{kg}$ dry (min) \\
\hline Water (\%) & $10 \%$ max. & $-50 \%$ & $-50 \%$ & $-50 \%$ \\
\hline DVB (\%) & 2 & 25 & 25 & 25 \\
\hline $\begin{array}{r}\text { Particle Size } \\
\text { (U.S. Mesh) }\end{array}$ & $-60 /+200$ & $-18 /+50$ & $-30 /+60$ & $-30 /+60$ \\
\hline $\begin{array}{l}\text { Bulk Density } \\
\left(\mathrm{Kgs}_{\mathrm{fft}}{ }^{3}\right)\end{array}$ & - & 27.2 & 26.2 & 25.2 \\
\hline $\begin{array}{l}\text { Average Pore } \\
\text { Size (A) }\end{array}$ & none & 450 & 600 & 600 \\
\hline
\end{tabular}




\section{RPP-RPT-50122 \\ Appendix B - Sorption Media Reference Matrix}

\section{Figure B-11. SuperLig( ${ }^{\circledR}$ Vendor Information (page 1 of 3)}

Date: Mon, 25 Apr 2011 13:01:27 -0600

From: rbruening(aibcmit.com

To: slzatt@ibcmrt.com; Rebecca_A_Robbins@rl,gov

Subject: Tc and SuperLigR 639 Questions

Dear Rebecca

The following is an answer to your questions. Please note that IBC does not have a copy of the dala reports for the SuperLigR 639 like we do for at least some of the SuperLigR 644 testing for Cs. Hence, much of the information we do not have the ability to send you the reports to give you back up graphs, etc. This information has been communicated to us largely by showing us data without giving us copies of reports, etc. Perhaps some of these reports are now public. We would be happy to comment on any of the reports you might have or could provide.

\section{Past testing summary}

SuperLigR 639 has been shown to have the ability to reduce the amount of Tc present as pertechnetate multiple orders of magnitude. Any Tc present in other oxidation states has not been removed. The tanks containing significant organics have shown levels of Tc up to $20 \%$ (and occasionally higher) that were not removable due to other oxidation states being present while most of the tanks have shown 99 to $99.9 \%$ Te removal. BNFL concluded that all requirements (as they were present in their time) could be met by mixing the outputs of the organic and non-organic containing tanks to reach the necessary Tc decontamination factor. All separation methods studied for Tc removal had the same issue and so the superiority of the SuperLigR 639 was based on its superior removal of the pertechnetate in tanks with high nitrate/nitrite and its ability to be eluted with water (rather than with large excesses of nitrate, etc.).

SuperligR 639 is a ligand covalently bound to polysytrene. Hence, its radiolytic stability is primarily the radiolytic stability of the polystyre ne (as per all other polystyrene based resins) which is around 1 x 107 rads. This has required that SuperLigR 639 and all other polystyrene and other organic supported resins for Tc removal be used after the Cs has already been removed to allow for many cycles of operation to be obtained.

SuperLigR 639 had to be prepared in a maximized density state (issue for all polystyrene based resins) in order for the resin not to float in some of the highest density feed solutions (density of 1.25 to $1.27 \mathrm{~g} / \mathrm{ml}$ ). This has already been achieved and demonstrated in production of the SuperLigR 639 later batches after this requirement was communicated to IBC.

Tc removal from a variety of tanks including high and low nitrate/nitrite, high and low organic content, high and low $\mathrm{K}$ with Te removal being very high for all pertechnetate in all cases and not removing the $\mathrm{Tc}$ present in other oxidation states has all been tested in columns of lab and pilot size. In all cases the Tc was eluted with deionized water. In cases where the high $\mathrm{K}$ was present the elution required $70 \mathrm{C}$ water instead of room temperature water.

\section{Resin Description}

Organic polystyrene support ( $0.5 \mathrm{~mm}$ beads) with covalently bonded ligands present. This is an elutable resin that is eluted in room temperature water except when the pertechnetate binds significantly as the $\mathrm{K}$ or ammonium salt (higher binding constants in this case) where $70 \mathrm{C}$ deionized water is required for elution. Superl.igR 639 had to be prepared in a maximized density state (issue for all polystyrene based resins) in order for the resin not to float in some of the highest density feed solutions (density of 1.25 to $1.27 \mathrm{~g} / \mathrm{ml}$ ).

\section{Details of Eluent}

This is an elutable resin that is eluted in room temperature water except when the pertechnetate binds significantly as the $\mathrm{K}$ or ammonium salt (higher binding constants in this case) where $70 \mathrm{C}$ deionized water is required for elution. The eluent in total usually requires approximately $10-15$ bed volumes at a flow rate of 0.1 bed volumes per minute. However, if desired the elution can be divided into two halves or three thirds with only the first outlet portion of the eluent sent to the Tc recovery section of the plant and the remaining tail of the elution recycled as the first part of the next elution. 


\title{
Figure B-12. SuperLig® Vendor Information (page 2 of 3)
}

\author{
Resin shelf life \\ 5-10 years
}

\section{Resin storage requirement}

Resin can be stored dry or in water.

\section{Resin handability}

Resin is readily handled similarly to standard IX resin as it has similar solid support and similar particle size. The difference is in the ligand present that has the high pertechnetate over other anion selectivity, but this does not affect the physical characteristics of the resin. SuperLigR 639 had to be prepared in a maximized density state (issue for all polystyrene based resins) in order for the resin not to float in some of the highest density feed solutions (density of 1.25 to $1.27 \mathrm{~g} / \mathrm{ml}$ ).

\section{Resin preparation/conditioning requirement}

Soak in water for 30 minutes or longer to wet and slurry pack into packed bed column. No other preparation/conditioning requirement to contend with. There is a slight shrink/swell of the material in going from neutral $\mathrm{pH}$ to basic $\mathrm{pH}$ and acidic $\mathrm{pH}$.

\section{Te Loading}

This varies with the level of Tc in the feed. Typical loading amounts are $70-200$ Bed volumes and then the amount of Tc loaded depends on the Tc level in the feed. For higher Tc feed levels, higher Tc loadings (not higher Bed volumes) have been obtained. It would be wise to obtain some of the lab and pilot reports from the DOE complex to be able to have examples of specific loadings for specific feed types and concentrations that are not available directly to IBC.

\section{Anticipated loading cycles before failure}

Determined primarily by when $1 \times 107$ rads of exposure are reached. Assuming the Cs is removed first, this exposure is expected to take around $100-200$ cycles to occur, but this will vary with the radiation level of the Tc and other radioactive elements present. Hence, you will want to check what the radioactivities of the different tank feeds are (with the Cs removed) to determine this for different tank feeds.

\section{Selectivity with respect to competing anions}

Virtually infinite selectivity over hydroxide, chloride, fluoride, and bromide. Selectivity over 2-3 M nitrate and nitrite of multiple orders of magnitude such that there is minimal effect on pertechnetate binding up to this range of nitrate/nitrite concentrations.

\section{Resin poisons}

No poisons found in tank feeds to this point in testing. Feed needs to be fully clarified prior to entry of resin column as solids can block physical access of pertechnetate to resin ligand sites. Note that this requirement is the case with any resin system and is not unique to SuperligR. Radioactivity stability to $1 \times 107$ rads.

Operating temperature range

Because the binding constants for the pertechnetate decrease with increasing temperature a temperature range of $5 \mathrm{C}$ to $40 \mathrm{C}$ is recommended. The elution, however, can either always be done at $70 \mathrm{C}$ or done at $70 \mathrm{C}$ with high $\mathrm{K}$ feeds

\section{Operating $\mathrm{pH}$ range}

No limit in either acidic, neutral, or basic range. The Tc binds to a completely neutral ligand as a total salt. Hence, the requirement for Tc binding is sufficient $\mathrm{Na}+, \mathrm{K}+, \mathrm{NH} 4+$, or $\mathrm{H}+$ being present.

\section{Process rate}

Loading, washing, and elution done at 0.1 Bed Volumes per hour.

Potential for gas generation (due to radiolysis)

Same as for other polystyrene based resins. 


\section{RPP-RPT-50122 \\ Appendix B - Sorption Media Reference Matrix}

\section{Figure B-13. SuperLig® Vendor Information (page 3 of 3)}

Estimate of Te remaining on spent resins

Less than $0.01 \%$ of Tc loaded on last loading cycle.

Suggestions for disposition of spent resins

Same methods applicable to other polystyrene based resins applicable to SuperLigR 639.

ROM cost/lb

Cost per $\mathrm{lb}$ is dependent on volume and commercial terms. SuperLigR 639 will, however, be economic based on all studies to date.

Development requirements

None that IBC is aw are of.

Technology risks

None that IBC is aware of.

I hope that this information is helpful to you.

Regards,

Ron Bruening

IBC Advanced Technologies, Inc.

(801) 763-8400 (phone)(

801) 763-8491

(fax) http://www.ibcmrt.com 
Figure B-14. TAM (Kurion, Inc)

\begin{tabular}{|c|c|}
\hline \multicolumn{2}{|c|}{ Contact Name/Phone/Email:_Dr. Mark S. Denton, 865-368-0979 } \\
\hline \multicolumn{2}{|c|}{ Influent } \\
\hline pH Range & $\geq 12$ \\
\hline Viscosity of Feed & $1-20 \mathrm{cP}$ \\
\hline \multicolumn{2}{|c|}{ Resin Type } \\
\hline Inorganic & $\mathrm{Y}$ or $\mathrm{N}$ \\
\hline Organic & $\mathrm{Y}$ or $\mathrm{N}$ \\
\hline \multicolumn{2}{|c|}{ If Known for Pertechnetate ( $\mathrm{CcO}_{4}$ ) Removal } \\
\hline $\mathrm{Kd}[\mathrm{Tc}] \quad$ Snll Apatite Microspheres (TAM) & $\begin{array}{c}\text { pH 8.6 WTP Recycle Surrogate: } 6.19 \mathrm{E}+01 \\
\text { pH 13.2 At tank AN-104 Surrogate: } 6.94 \mathrm{E}+02\end{array}$ \\
\hline Selectivity to Tc & $\begin{array}{l}\text { Extremely specific at high salt molarity and high } \\
\mathrm{pH}\end{array}$ \\
\hline Poisons & Neither salts nor chelants seem to have an affect \\
\hline Equivalents/L & $\sim 2.25-2.50$ \\
\hline \multicolumn{2}{|c|}{ Resin Properties } \\
\hline Preparation Procedure & $\begin{array}{c}\text { Sn II substitution for } \mathrm{Ca} \text { in Hydroxy Apatite } \\
\text { (CaPO4) Microsphere production. Glass substrate } \\
\text { initiator. }\end{array}$ \\
\hline Radiological Stability and/or Gas Generation & Extreme rad stability. No know gas generation. \\
\hline Bed Volumes per Hour Operation & Depends on application. \\
\hline Particle Size & $20-50$ mesh $\sim 300-850$ micron \\
\hline Elutable & Unknown at this time \\
\hline Eluant & Ditto (the object is to trap Tc-99, not elute it) \\
\hline Storage, Shelf Life & Indefinite \\
\hline Handling Specifications & No special specs. \\
\hline Loading Cycles & See above. \\
\hline Resin Density (weight per unit volume) & $\sim 1.37 \mathrm{~g} / \mathrm{cc}$ \\
\hline $\mathrm{pH}$ operating range & $6.5-14$ (not for acidic conditions) \\
\hline Temperature operating range & $\begin{array}{l}\text { Made from glass microspheres at high temperatures. } \\
\text { So none known. }\end{array}$ \\
\hline Cost per Pound (or $\mathrm{ft}^{3}$ ) & To be specified. \\
\hline Ability to supply amounts of $\geq 2000$ lbs & Depends on time frame specified. \\
\hline
\end{tabular}

